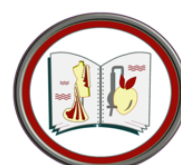

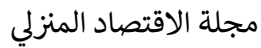

جامعة المنوفية، شبين الكوم، مصر الوقئر

https://mkas.journals.ekb.eg

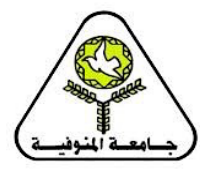

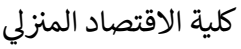

الاقتصاد المنزلي والتربية

\title{
فاعلية برنامج إرشادي معرفي سلوكي لتنمية توكيد الذات وأثره على أساليب مواجهة الضغوط لدى طلاب كلية الاقتصاد المنزلي
}

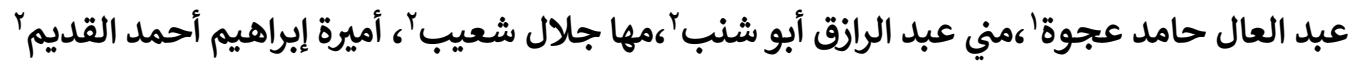

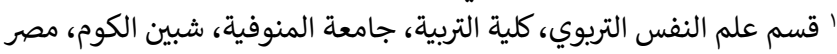
r قسم الاقتصاد المنزلي والتربية، كلية الاقتصاد المنزلي، جامعة جامعة المنوفية، شبين الكوم، منية، شبين الكوم، مصر

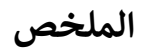

هدف البحث الحالي الكشف عن فاعلية برنامج إرشادي معرفي سلوكي في تنمية توكيد الذات وأثره على أساليب

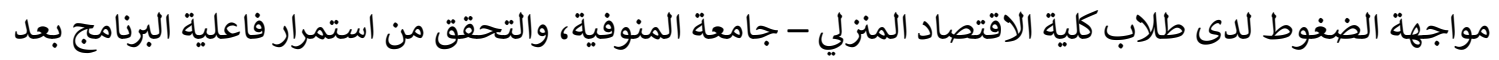

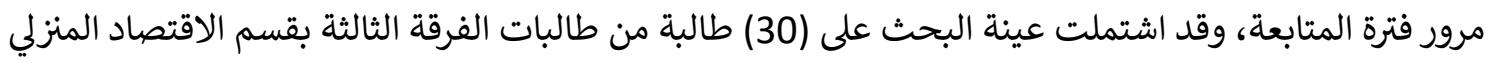

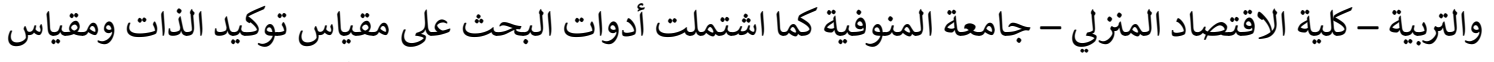

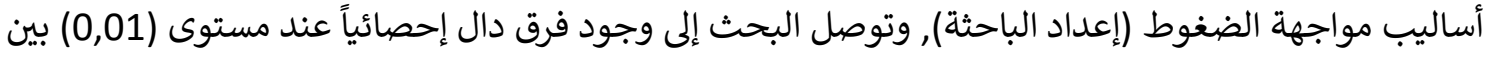

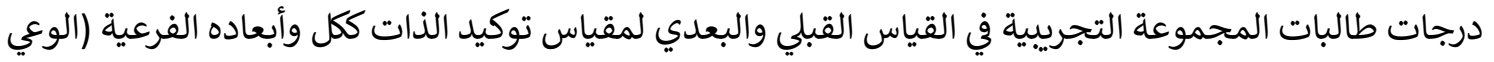

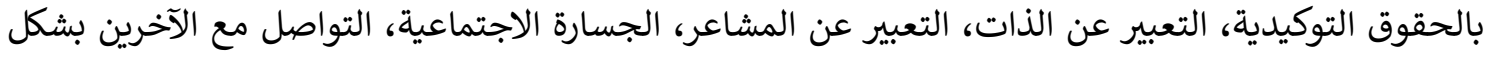

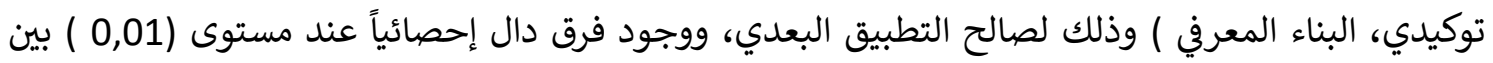

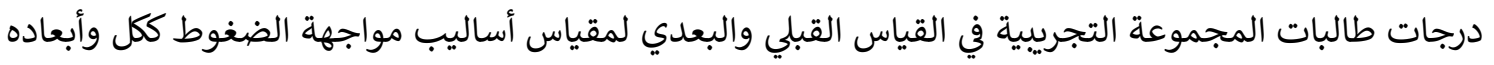

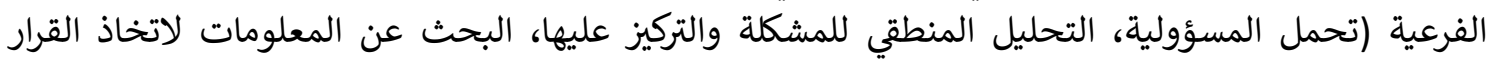

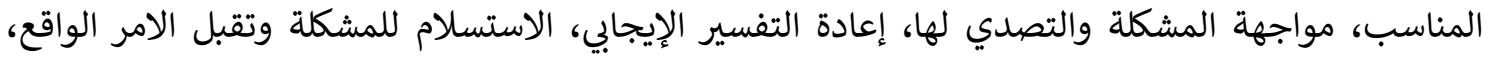

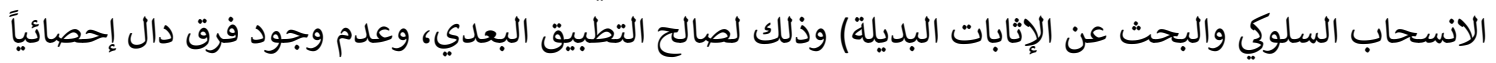

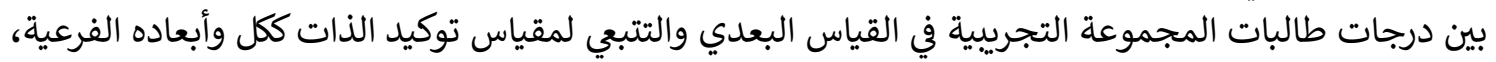

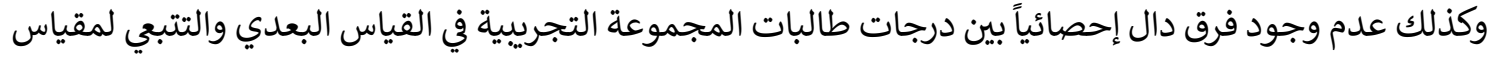

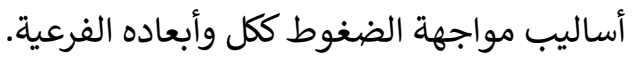

الكلمات المفتاحية: الارشاد المعرفي السلوكي -توكيد الذات - أساليب مواجهة الضغوط-

JHE, 2021, 31(2): pp 267-308 . يتم طباعتها في جامعة المنوفية، جميع حقوق الطبع محفوظة للمجلة. 


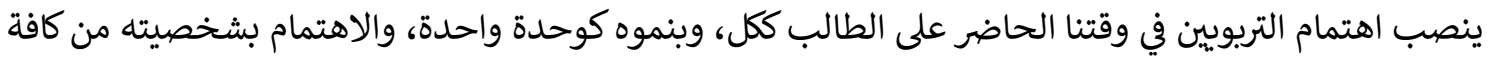

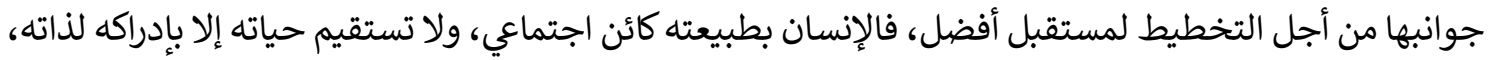

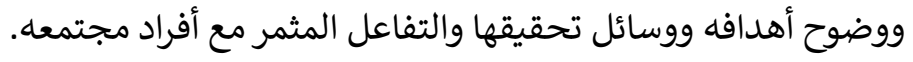

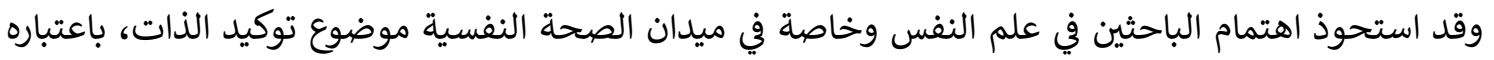

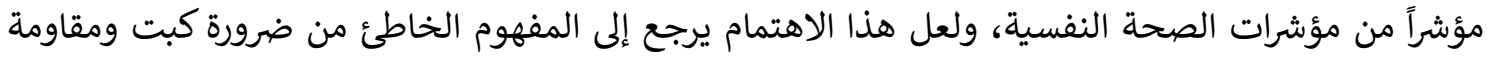

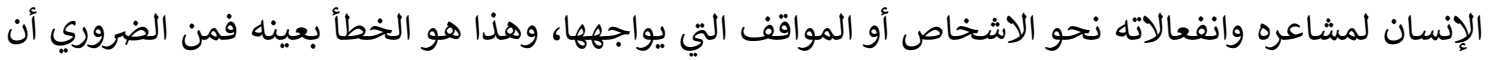

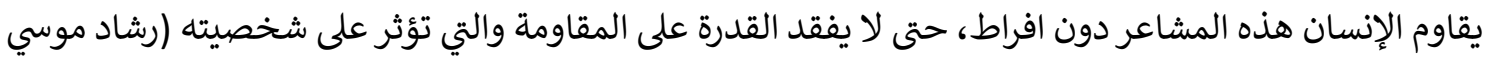
ومديحة الدسوقي،2011). ويعبر توكيد الذات عن تلقائية الفرد في الأقوال، والأفعال، وفي الحركات التعبيرية، والإيماءات، وفي الأسئلة،

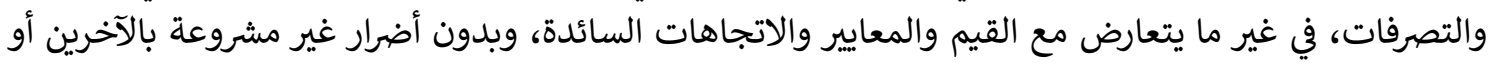

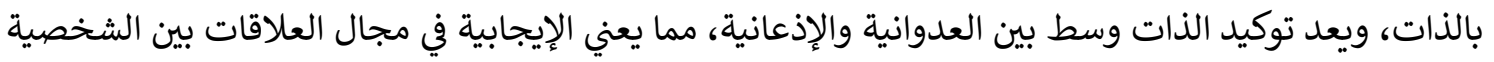
(معتز عبيد،2008).

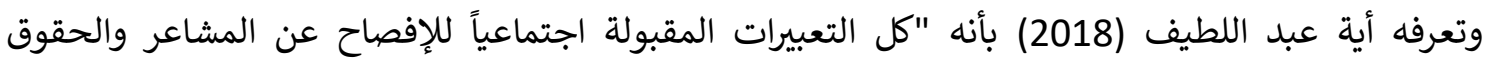

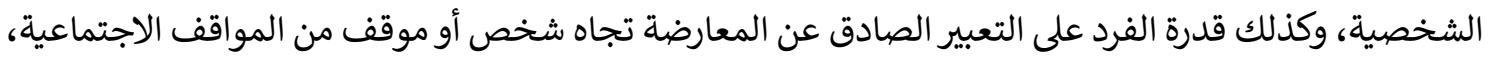

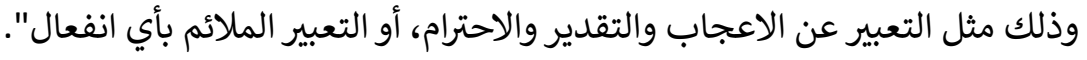

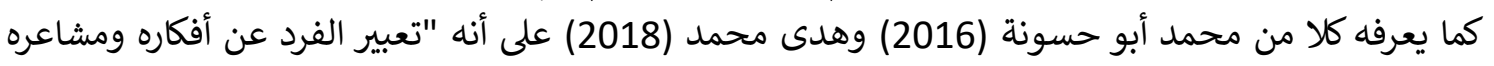

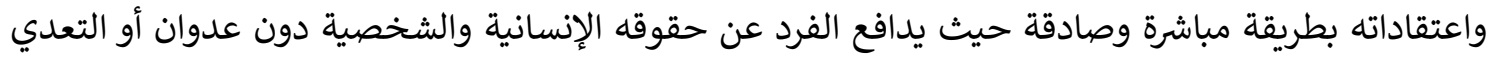

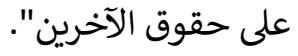
وحدد كثير من الباحثين في هذا المجال أبعاد السلوك التوكيدي مثل الرفض، والثقة بالذات في مواقف العلاقات

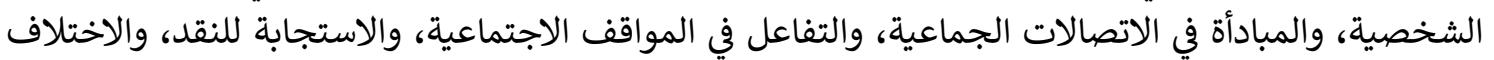

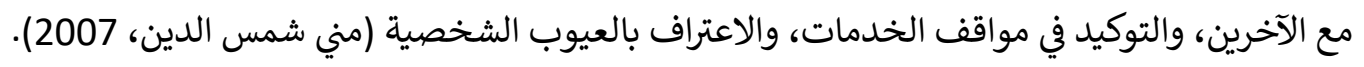

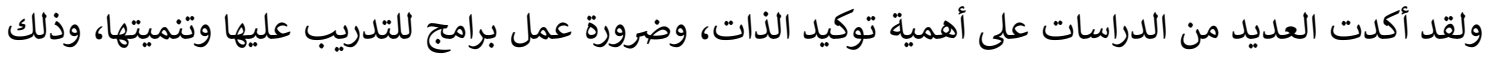

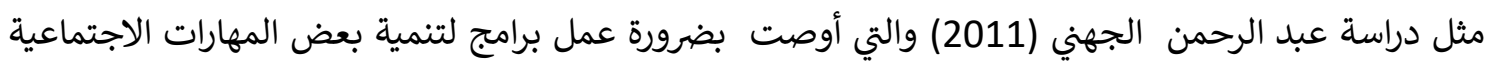

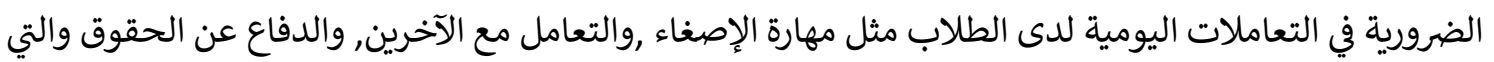

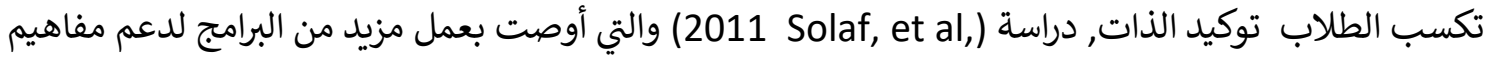

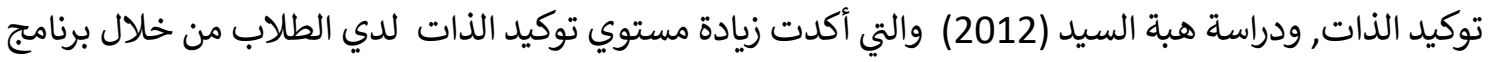

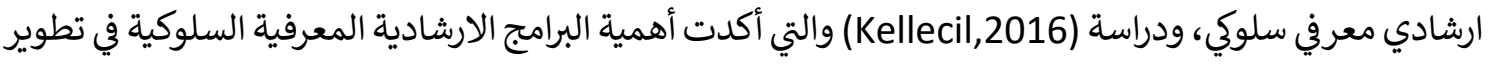
السلوك التوكيدي لدى الطلاب.

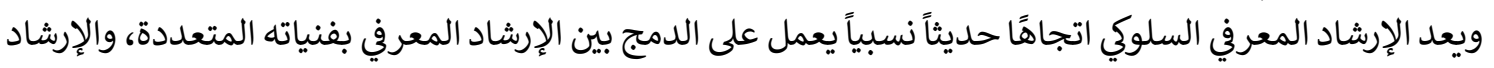

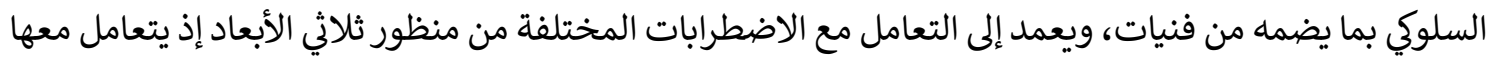


معرفيًا وسلوكياً ووجدانياً، ويعتمد هذا الاتجاه الإرشادي على الإقناع الجدلي التعليمي، وتوضيح العلاقة بين الأفكار

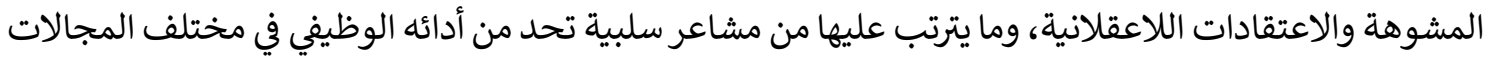

(هبة السيد، 2012). ولأن مرحلة المراهقة تتميز بمشاعر الوحدة، وهذا الأمر ليس بغريب على الئ المراهقين، وذلك لأنهم يجلسون

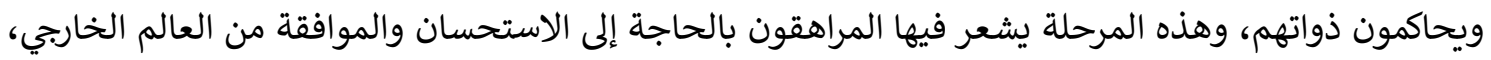

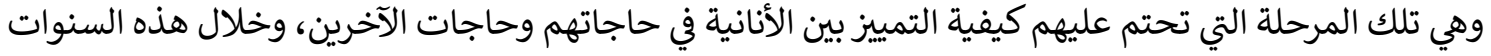

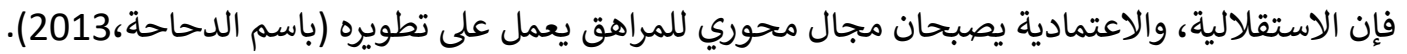

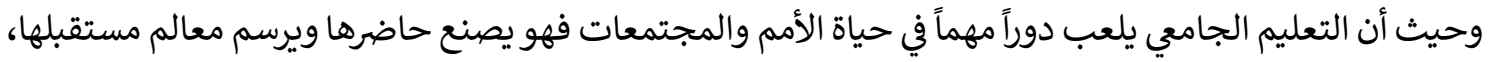

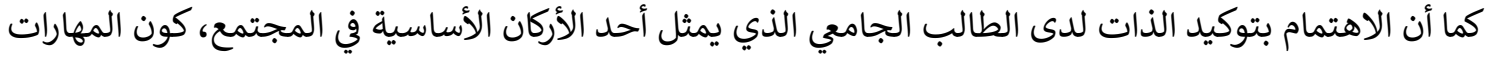

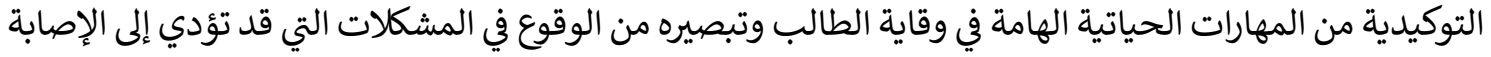

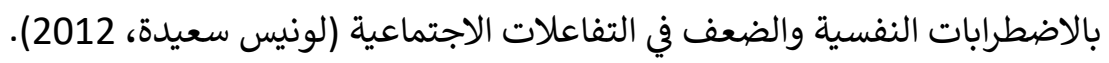
الاحساس بمشكلة البحث:

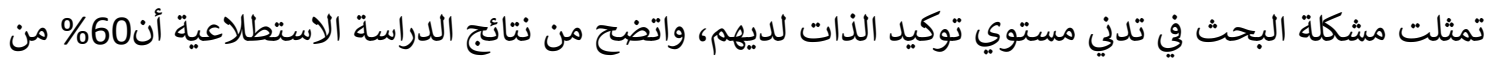

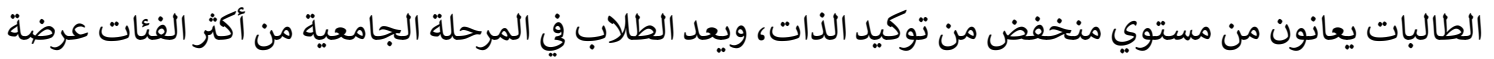

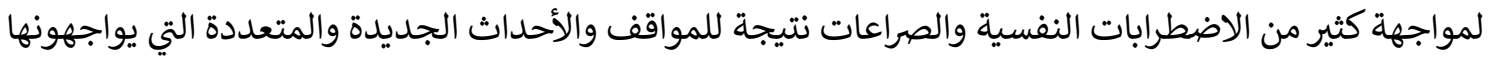

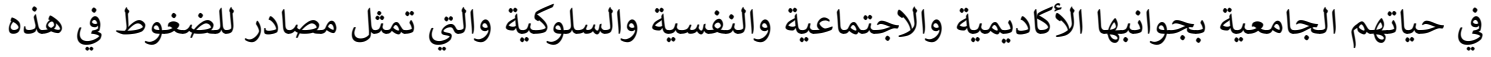
المرحلة (زينب أبو الغيط، أنها:2016). وأكدت أمل الأحمد ورجاء محمود (2009) على أن أنفيط، معاناة الطلاب من المشكلات والضغوط ترجع في بعض أسبابها

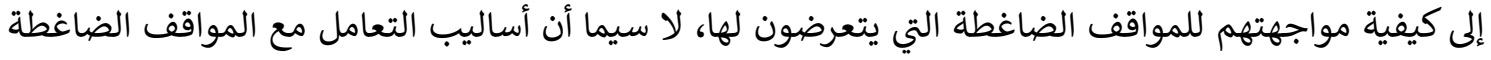

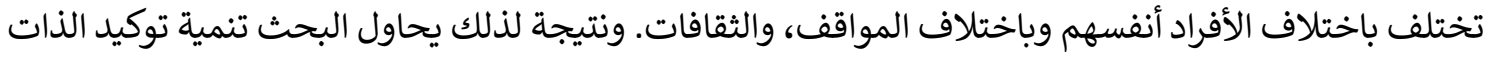

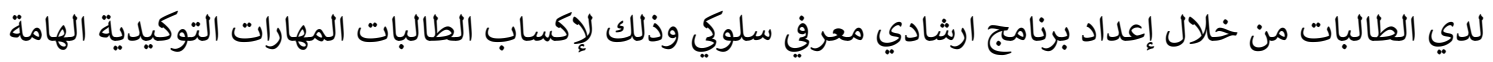

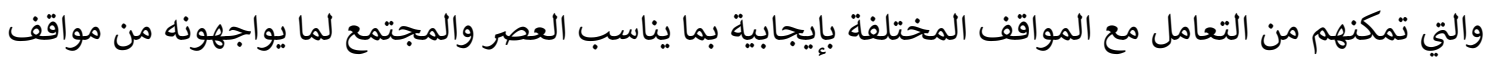

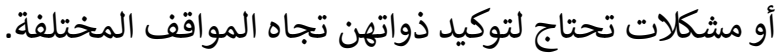
تحددت مشكلة البحث في السؤال الرئيس التالي: ما فاعلية البرنامج الإرشادي المعرفي السلوكي في تنمية توكيد الذات وما أثره على أساليب مواجهة الضغئين الضوط لدئي

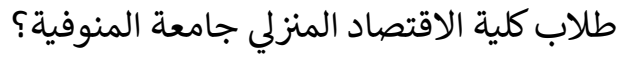

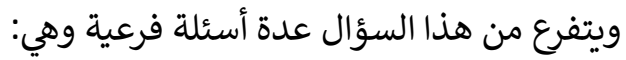

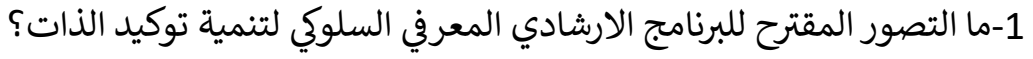

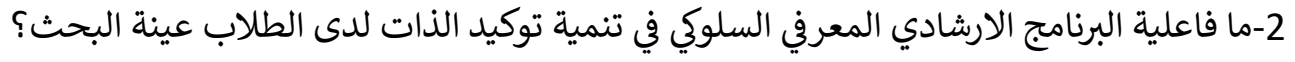


3-ما أثر البرنامج الارشادي المعرفي السلوكي في تنمية توكيد الذات على أساليب مواجهة الضغوط لدى الطلاب

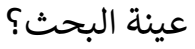
4-هل تستمر فاعلية البرنامج الارشادي المعرفي السلوكي في تنمية توكيد الذات ويستمر أثره على أساليب مواجهة

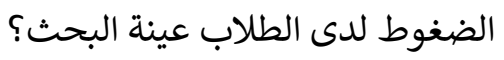

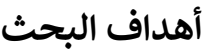

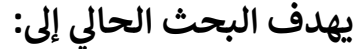

1. تصميم برنامج يعتمد على الارشاد المعرفي السلوكي في تنمية توكيد الذات لدى عينة من طلاب كلية

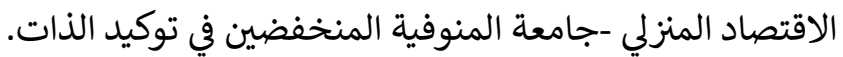

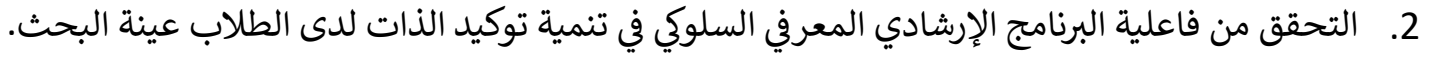

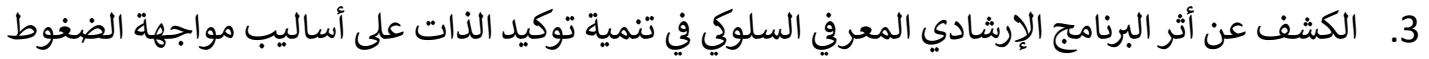

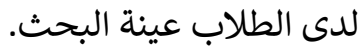

4. التعرف على استمرارية فاعلية البرنامج الإرشادي المعرفي السلوكي في تنمية توكيد الذات واستمرار أثره

على أساليب مواجهة الضغوط في مرحلة المتابعة لدي الطلاب عينة البحث.

تكمن أهمية البحث الحالي فيما يلي: الأهمية

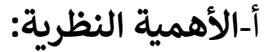

• -إلقاء الضوء على أهمية البرامج الارشادية المعرفية السلوكية في تنمية بعض الجوانب الهامة في

الشخصية.

- توفير المعلومات الكافية لدي الطلاب عن توكيد الذات باعتباره مكون أساسي في الشخصية، حيث

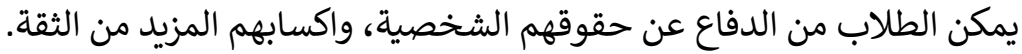

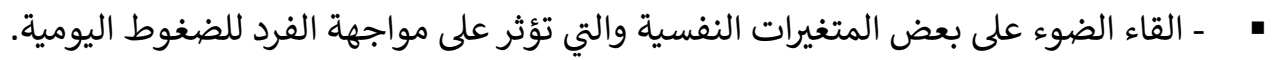

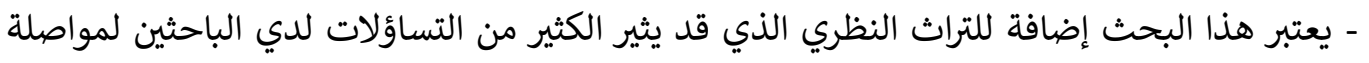

$$
\text { البحث في هذا المجال. }
$$

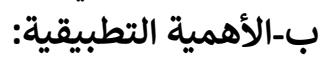

ـ الاهتمام بالفئة التي نتعامل معها وهي فئة طلاب الجامعة، الذين يقع عليهم عبء مسئولية النهوض

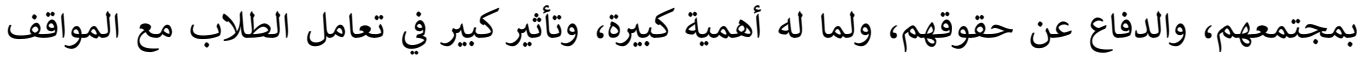
الضاغطة المختلفة التي يتعرضون واعن عنون لهان

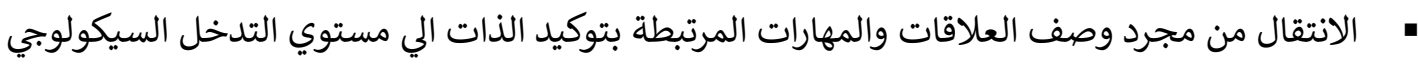

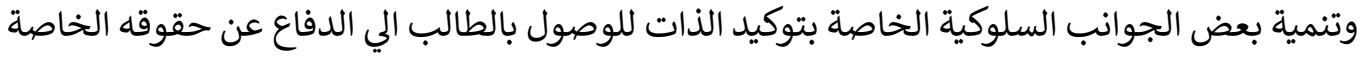

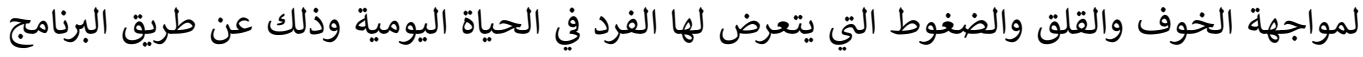

$$
\text { الإرشادي المقدم لهم الخوف والمق }
$$


• - تقديم برنامج إرشادي معرفي سلوكي لتنمية توكيد الذات لدي طلاب الجامعة، وتخريج جيل جديد

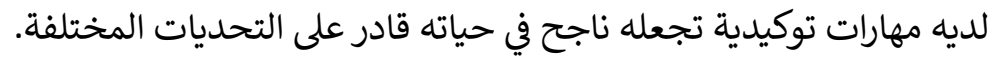

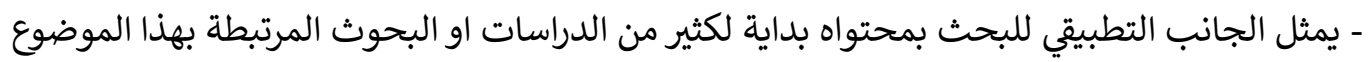

بصورة علمية وشاملة.

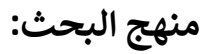
استخدمت الباحثون المنهج الوصفي والمنهج شبه التجريبي نظراً لملاءمتهما لطبيعة إجراءات البحث. عينة البحث اشتملت عينة البحث في شكلها النهائي على (30) طالبة من طالبات الفرقة الثالثة ـكلية الاقتصاد المنزلي -جامعة

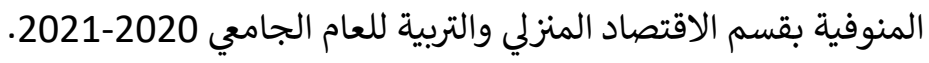
حدود البحث

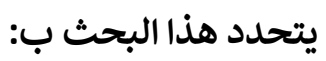
1-الحدود الموضوعية: اقتصرت على البرنامج الارشادي المعرفي السلوكي لتنمية توكيد الذات وأثره على أساليب مواجهة الضغوط. 2-الحدود البشرية: طالبات الفرقة الثالثة ـكلية الاقتصاد المنزلي -جامعة المنوفية بقسم الاقتصاد المنزلي والتربية لكام الجامعي 2020-2021.

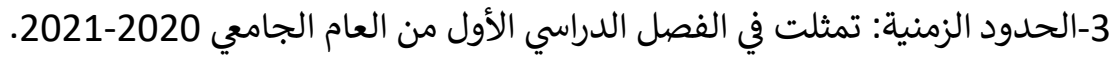

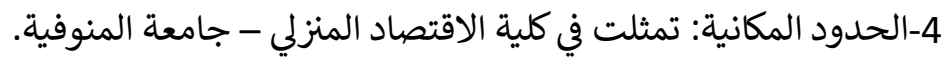
مصطلحات البحث توكيد الذات: Self-assertiveness يعرف إجرائيا بأنه مجموعة من المهارات السلوكية اللفظية، وغير اللفظية، والنوعية، والموقفية المتعلمة ذات

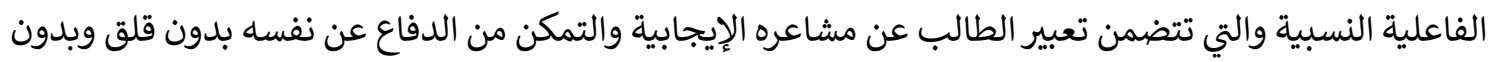

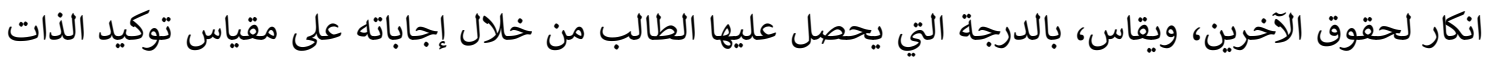

(إعداد الباحثون).

أساليب مواجهة الضغوط:Coping Styles With Stresses تعرف اجرائيا بانها: مجموعة من الأساليب التي يستخدمها الطالب ويلجأ اليها عندما يمر بأزمة أو مشكلة فيحاول

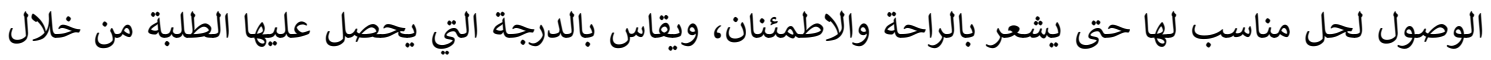

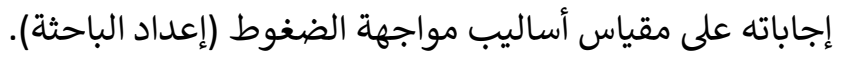

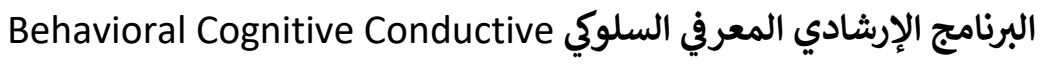

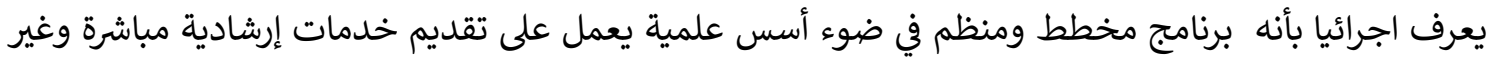

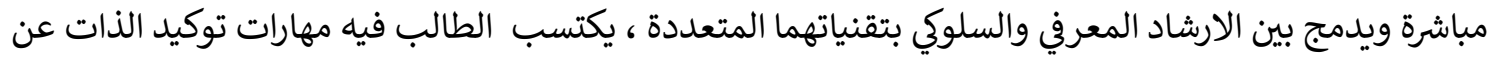

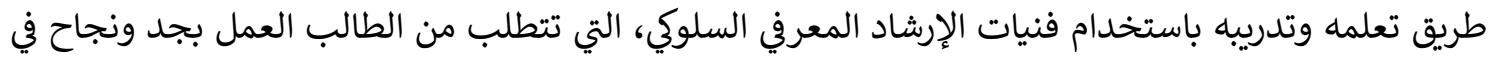


الوقت الذي يتعرض فيه لمواقف وضغوط وأفكار وذلك من خلال اكسابه الثقة بالنفس، والقدرة على تحمل

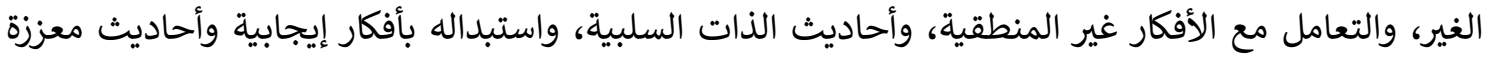

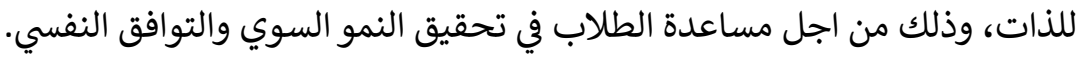

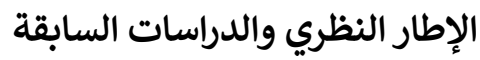

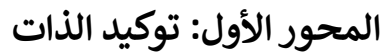
مفهوم توكيد الذات تعرفه هويدة حنفي (2009) بأنه " وسيلة الفرد للتعبير الصادق عن أرائه وانفعالاته، ومهاراته في تكوين العلاقات الإتهات

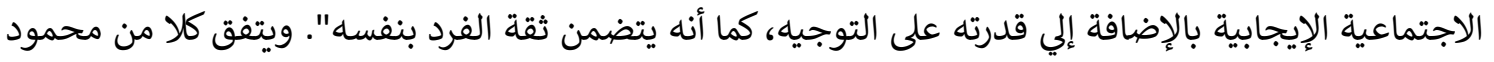

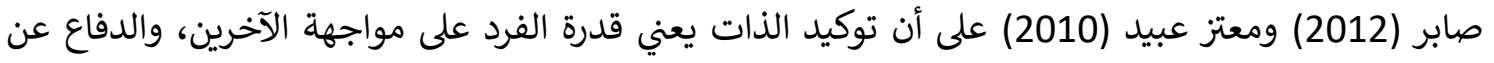

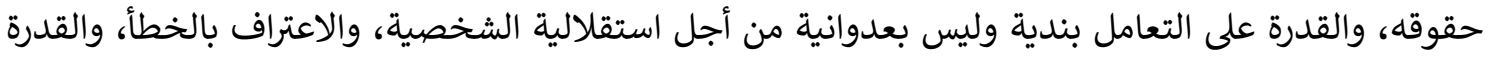

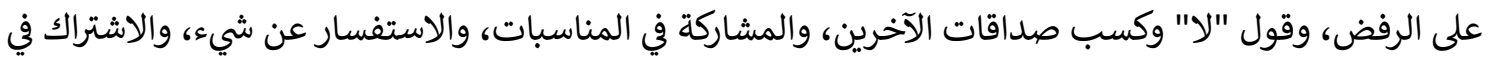

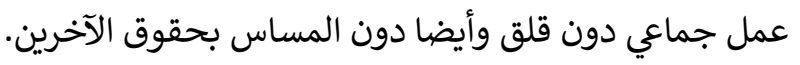
أهمية توكيد الذات:

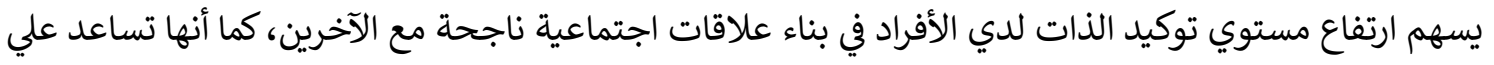

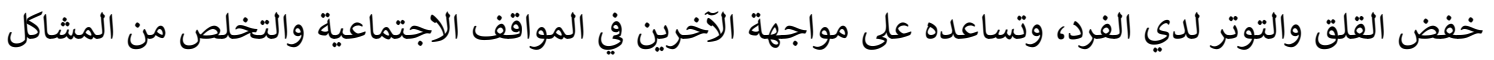

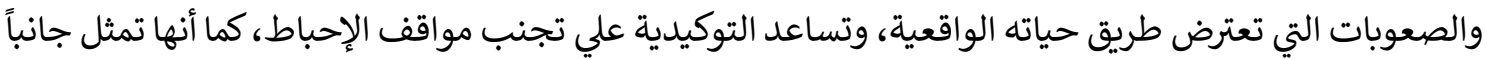

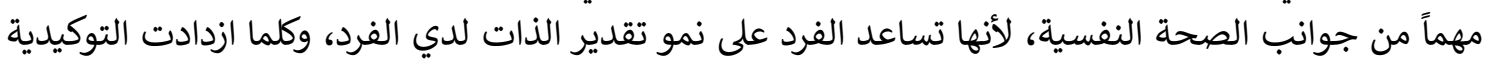

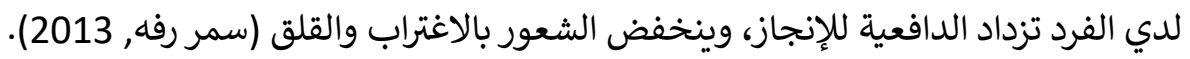

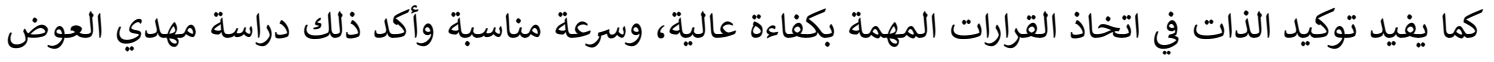

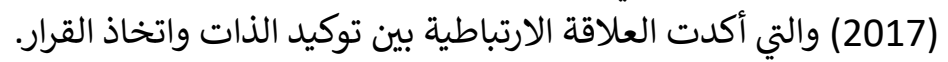

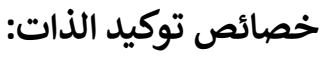
ذكر كلاً من رمضان الحلو (2012) وناصر الدين أبو حماد (2014) ومحمد أبو حسونة (2016) وريهام أبو فايد (2016) خصائص توكيد الذات كالاتي:

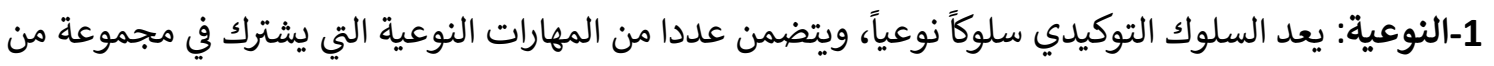

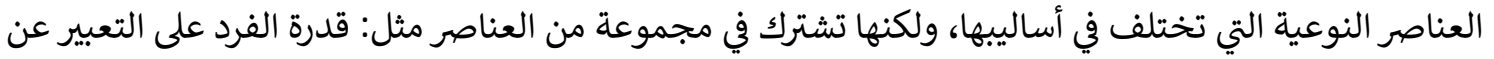

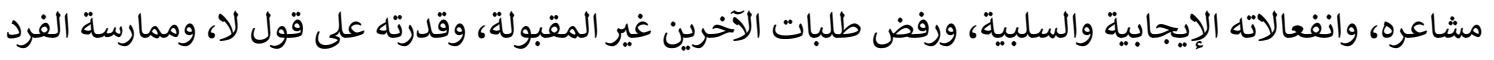

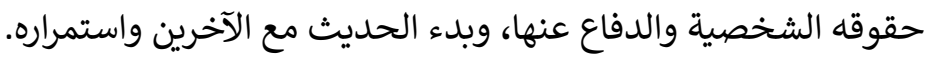

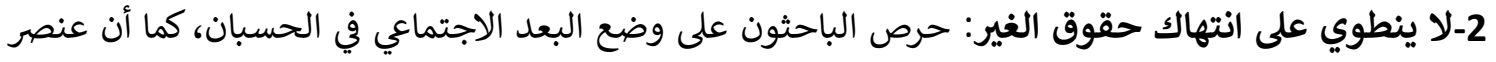

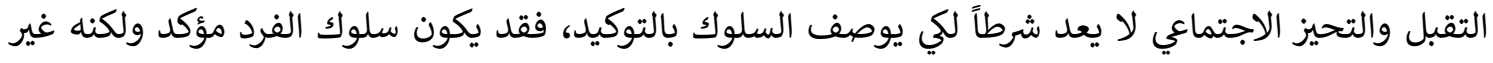
مقبول، كمن يعرض وجهة نظر مخالفة لرئيسه علانية بطريقة مهذبه لإنديه ولديه مبررات قوية. 
3-فعاليته النسبية: التوكيد ليس فعال دائما، فالسلوك التوكيدي قد يجلب المزيد من المتاعب على الفرد،

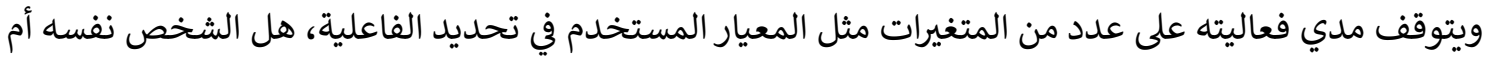

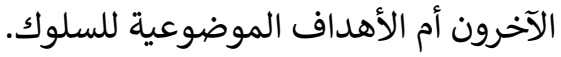

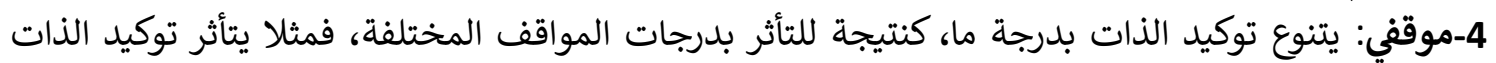

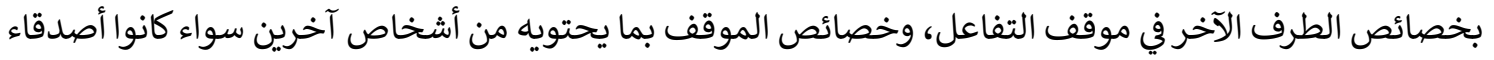

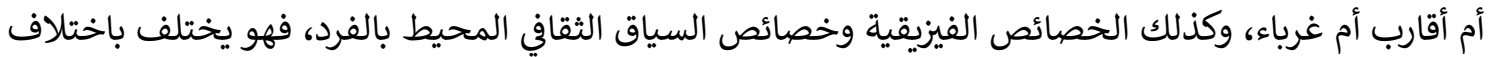

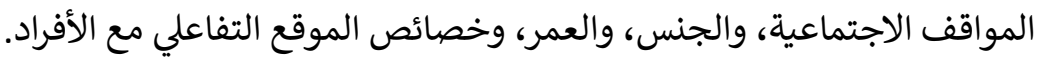

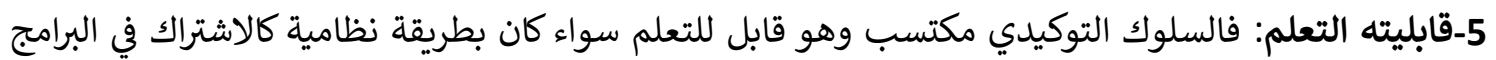

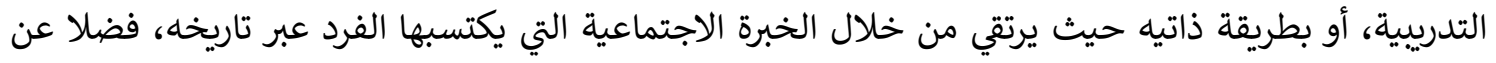

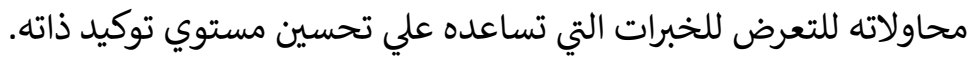

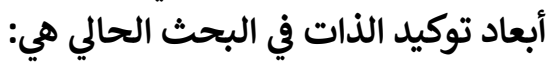
1-الوعي بالحقوق التوكيدية: وهو قدرة الطالب علي الدفاع الداع عن حقوقه الشخصية وآرائه الفردية المشروعة سواء

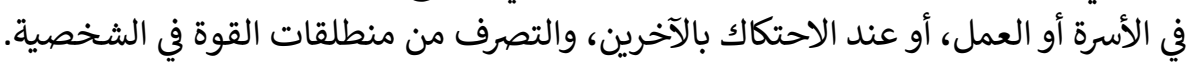

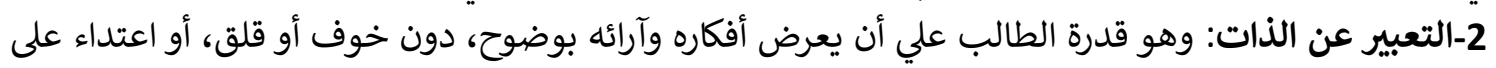

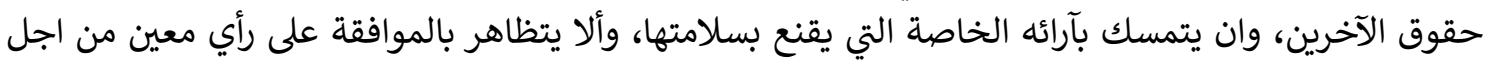
المحافظة على السلامة والهدوء.

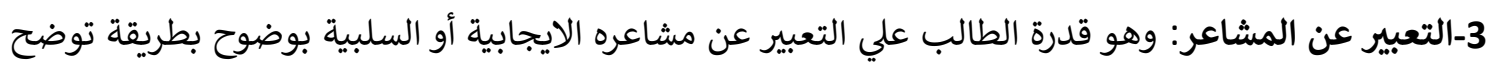

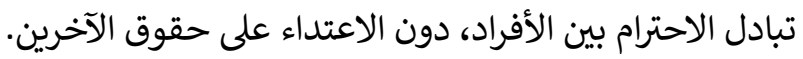

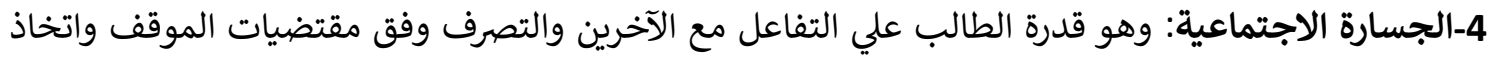

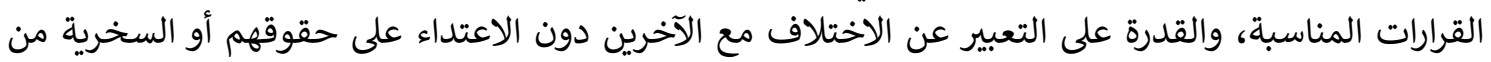

5-التواصل مع الآخرين بشكل توكيدي: وهو قدرة الطالب علي التعبير عن أفعاله وتصرفاته التوكيدية بنبرات

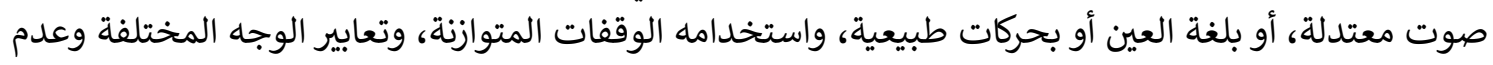

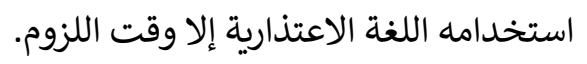

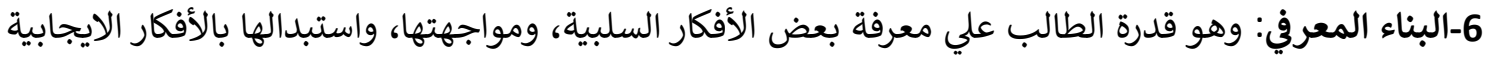

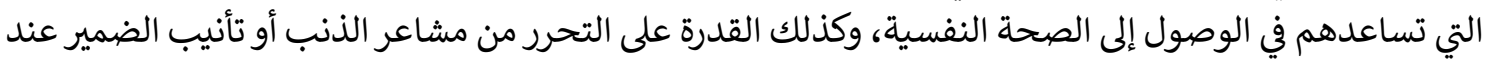

رفض هذه المواقف والأفكار.

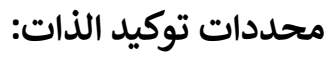

هناك عدد من المتغيرات تمارس تأثيراً كبيراً في تفسير السلوك التوكيدي، وهذه المتات المتغيرات تشمل عدة فئات تحتوي

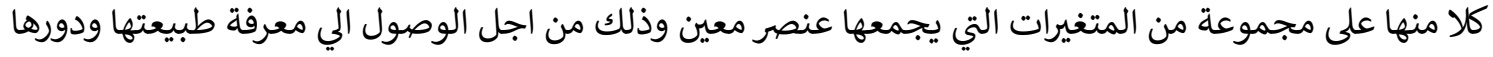

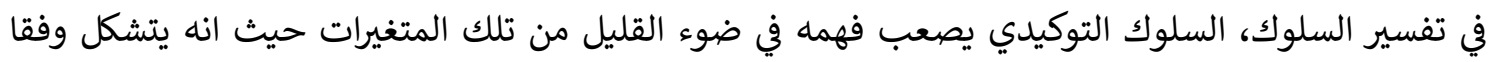


لمحددات شخصية وثقافية واجتماعية، وتلك المتغيرات تتحدد في خمسة متغيرات تضم العديد من الأبعاد كما يلي:

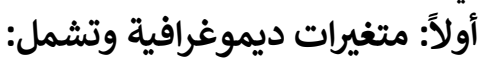

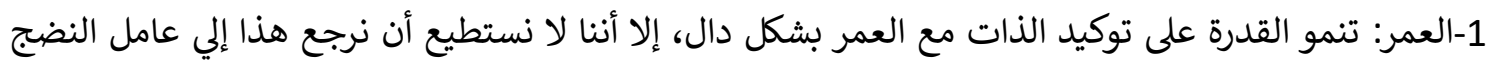

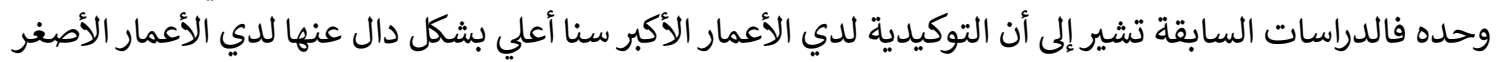

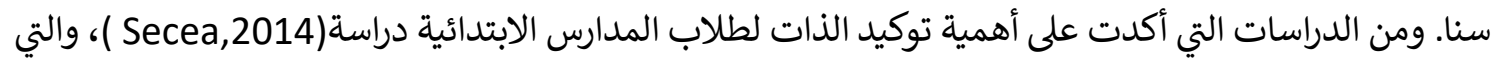

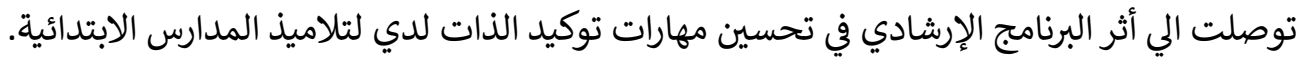

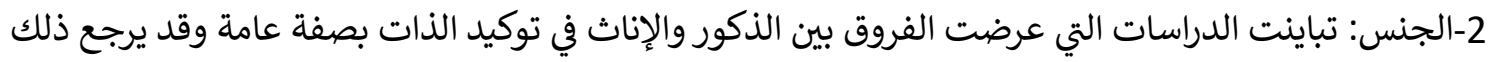

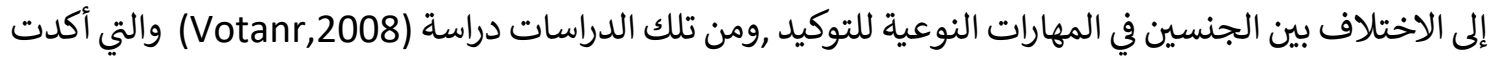

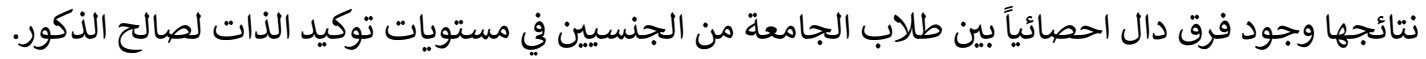

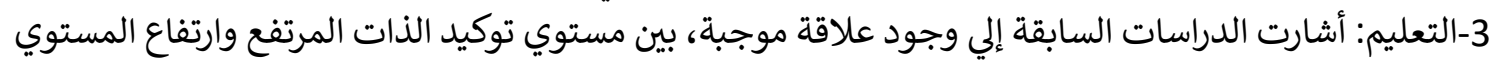

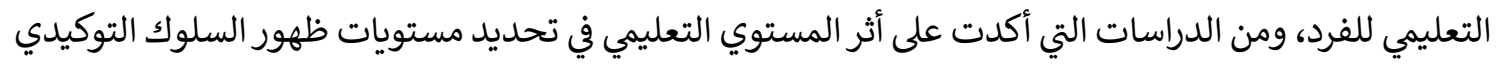

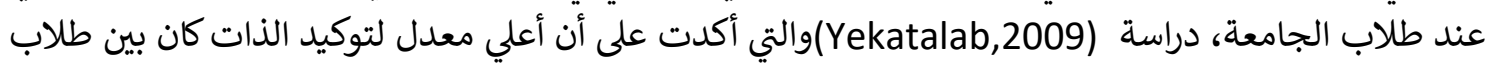

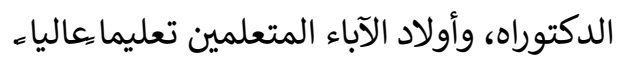

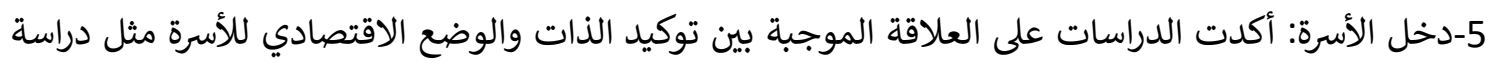

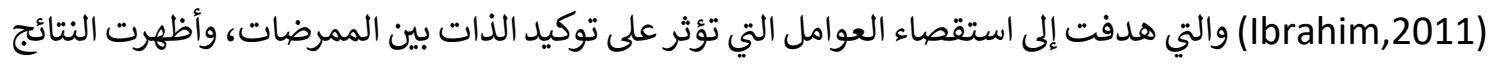

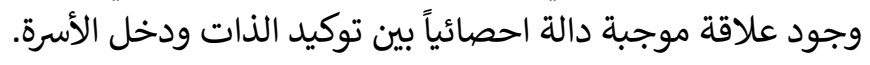
ثانياً: متغيرات انفعالية (مزاجية) وتشمل: والة احتية 1-القلق: ومن الدراسات التي بحثت العلاقة بين القلق وتوكيد الذات، ونات دراسة نايف الحراتية الحربي (2013) وأشارت

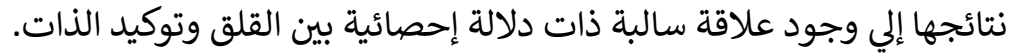

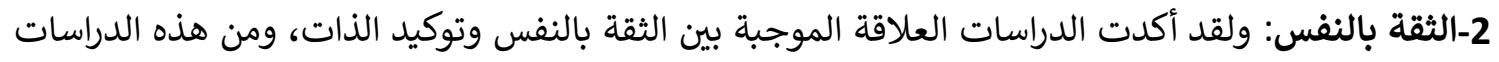

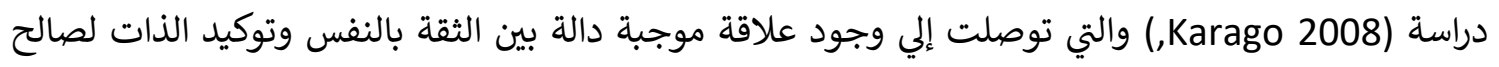
المجموعة التجريبية من طلاب كلية التمريض. 3-الاكتئاب: ولقد أكدت العديد من الدراسات وجود طابت علاقة سالبة بين الاكتئئاب والسلوك التوكيدي، ومن

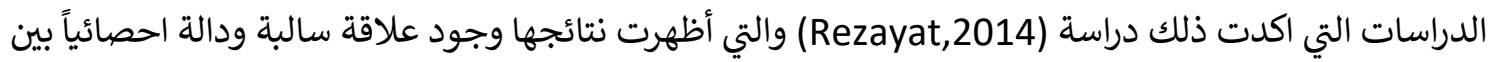

$$
\text { توكيد الذات والاكتئاب. }
$$

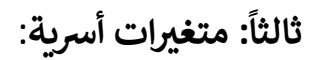

ومن الدراسات التي أكدت العلاقة بين نمط التنشئة وتوكيد الذات دراسة سمر رفة (2013) والتي توصلت إلى

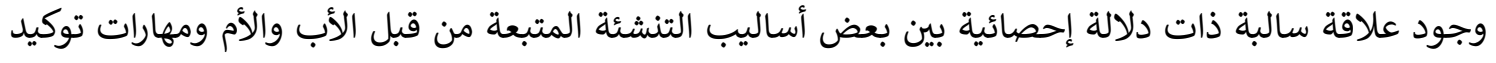

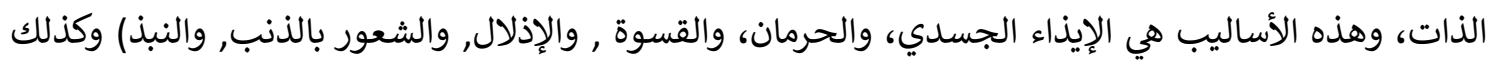

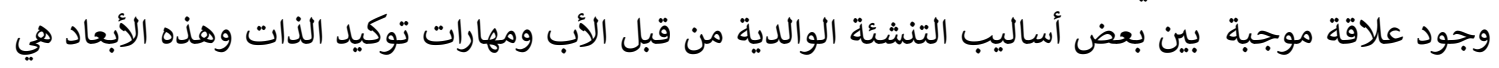


(التعاطف الوالدي, التوجيه للأفضل, التشجيع, كما أسفرت دراسة (Liyaghat,et al,2011) عن ارتفاع توكيد الذات لدى الأسر الكثيرة الحب لأبنائها.

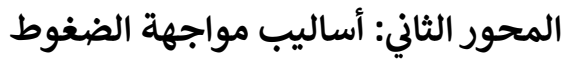

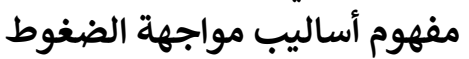
تعرف أساليب مواجهة الضغوط بأنها الطريقة أو الوسيلة التي تساعد الفرد علي مواجهة ضغوط الضوط الحياة والتعامل

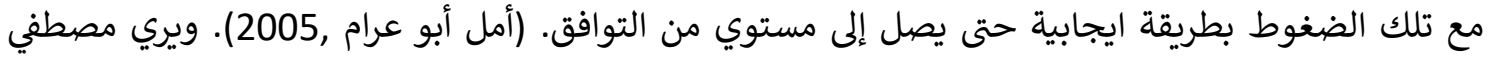

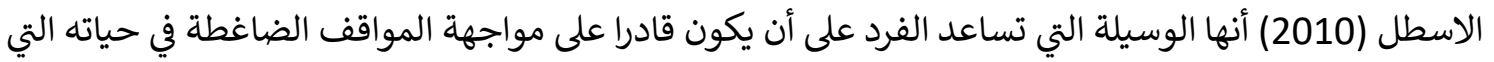

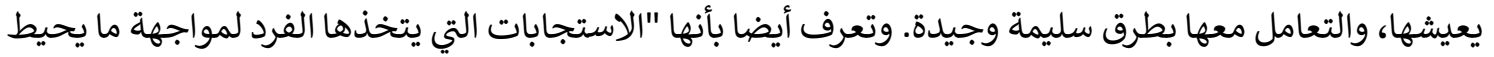

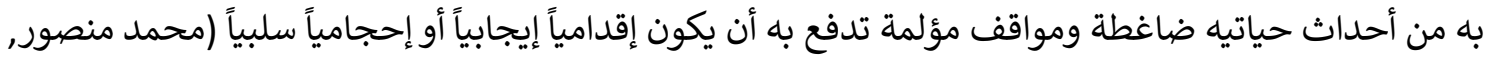

وظائف أساليب مواجهة الضغوط

تشير سارة سعدة (2016) عدة وظائف لأساليب المواجهة الئه وهي:

1-قدرة الفرد على التعامل مع مطالب البيئة الاجتماعية وخلق الدافع لتلبية تلك الحاجة.

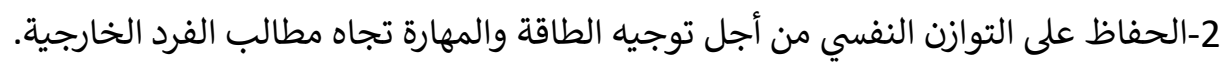
3-الحفاظ على توفير المعلومات الكافية حول بيئة الفرد.

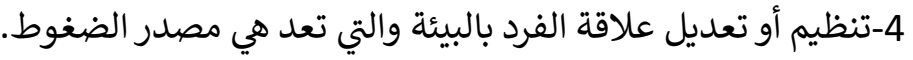
5-التفاعل مع الانفعالات الضاغطة.

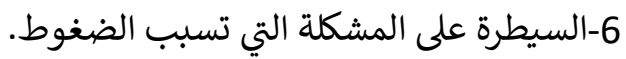
سمات الشخصية ومواجهة الضغوط:

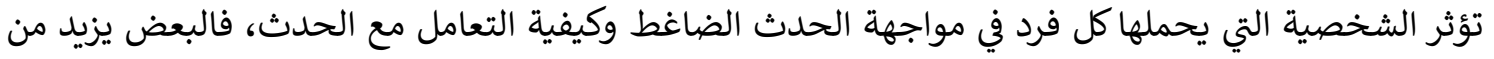

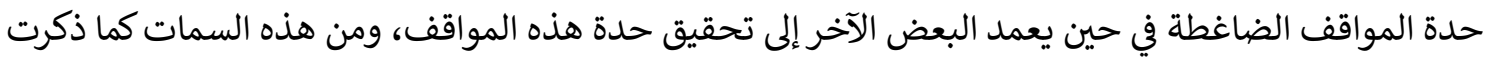
(سارة طلبة, 2016) 1-النمط التشاؤمي: هناك بعض الأفراد يتصفون بالميل إلى تفسير الأحداث السلبية من منطلق خصائصهم العامة،

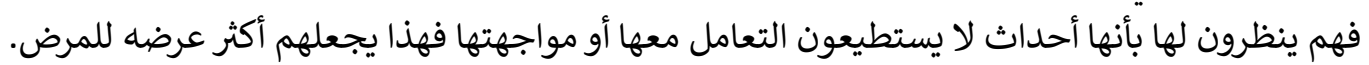

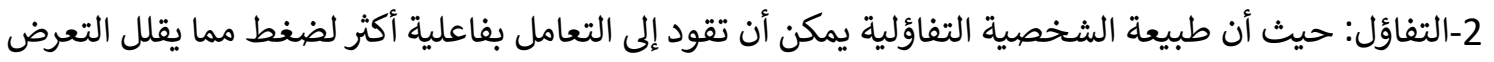

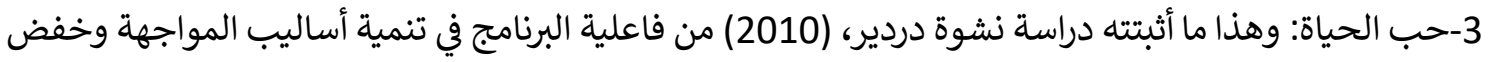

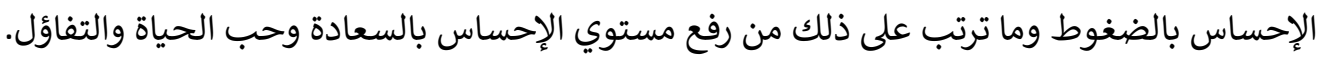

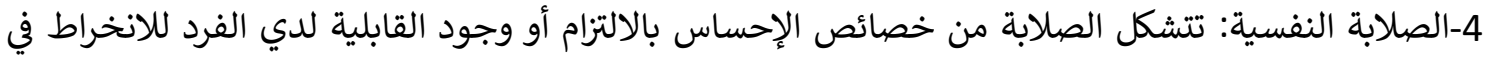

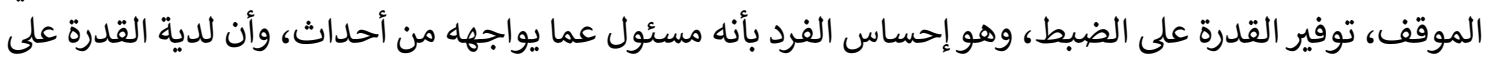
التأثير في ظروف بيئته، الاستعداد لتقبل التغيير ومواجهة الأحداث الضاغطة وفئ (شيلي تايلور, 2008). 
ومن الدراسات التي أثبتت العلاقة بين الصلابة النفسية وأساليب مواجهة الضغوط دراسة (خالد العبدلي ,2012؛ ودراسة أسماء زهاني ,2014) والتي أكدتا على وجود علاقة ارتباطية موجبه بين الصلابة النفسية وأساليب مواجهة الضغوط. 5-السعادة النفسية وفاعلية الذات :وهذا ما أثبتته دراسة زينب أبو الغيط (2016) من وجود ارتباط موجب دال

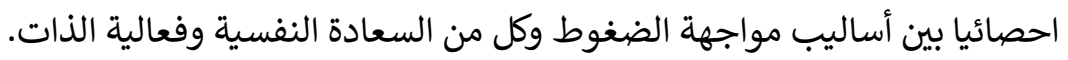

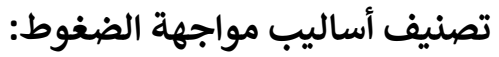

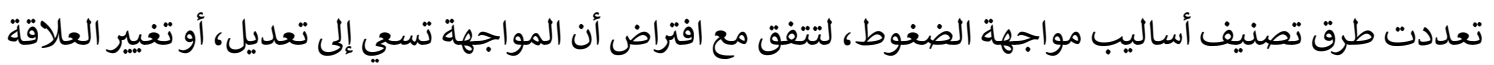

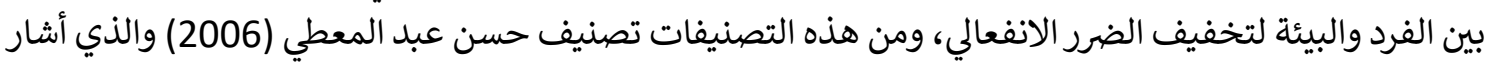

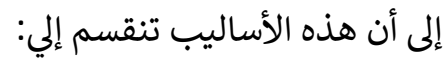
أ: الأساليب البدنية (النفس جسمية): وتشمل ممارسة الرياضة، النشالئ النفاط الجمسي، التنظيم، التغذية، الاسترخاء والتغذية الراجعة البيولوجية.

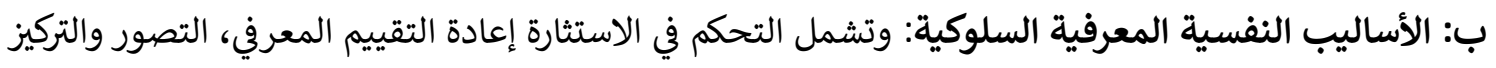

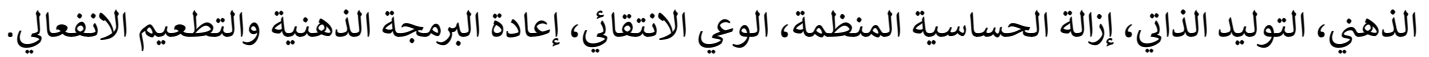

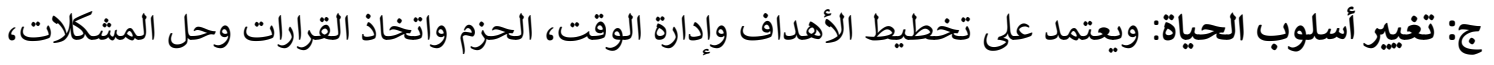

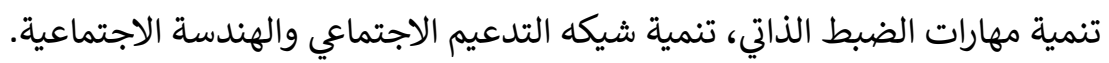
د: الأساليب الوجودية والروحية: وتشمل التفكير في معني الحياة والتمسك التئ بالدين.

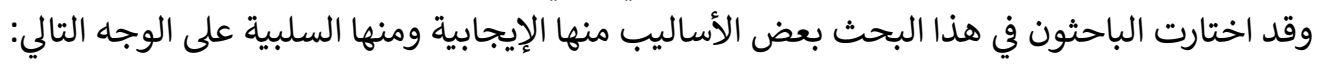
أولاً: أساليب المواجهة الإيجابية:

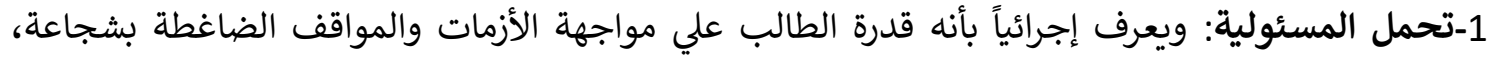

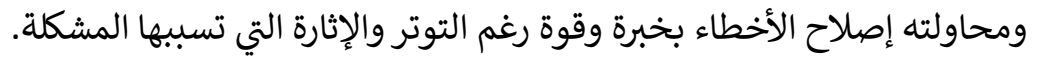

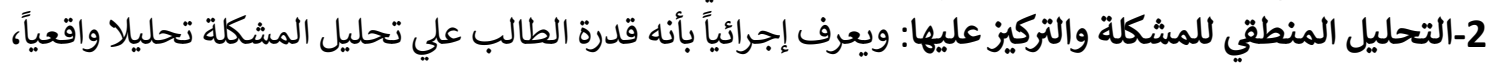

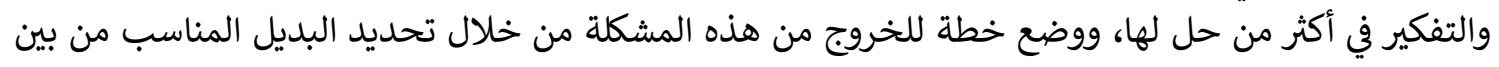
البدائل المتاحة.

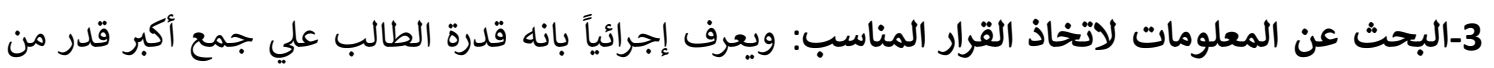

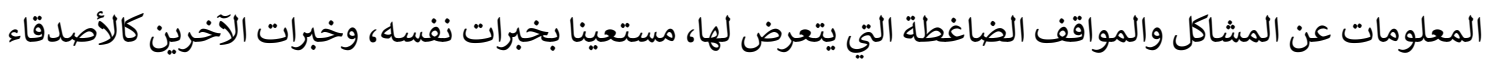

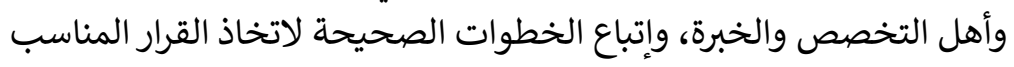

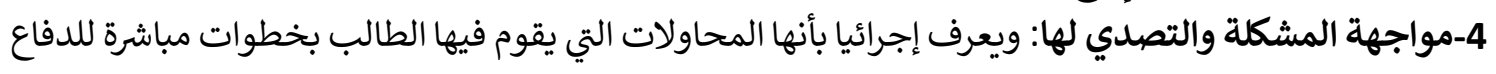

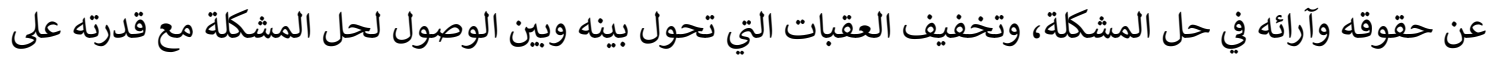
إقناع الآخرين. 
5-إعادة التفسير الإيجابي: ويعرف إجرائيا بأنه: محاولة الطالب رؤية بعض الجوانب الإيجابية أثناء مواجهة

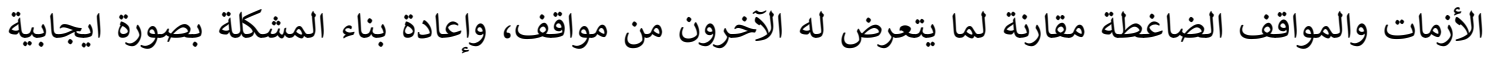

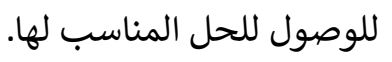

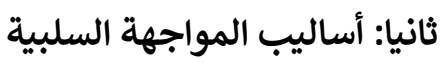

1-الاستسلام للمشكلة وتقبل الأمر الواقع: ويعرف إجرائياً بأنه عبارة عن نشاط معرفي يقود بالطالب إلي تقبل

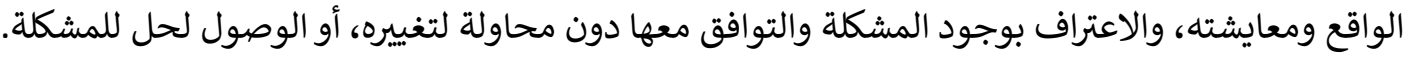

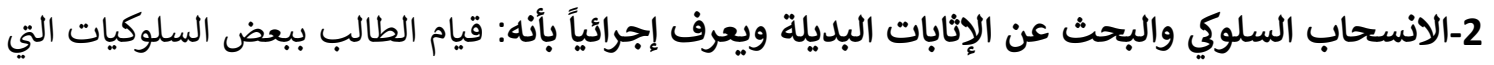

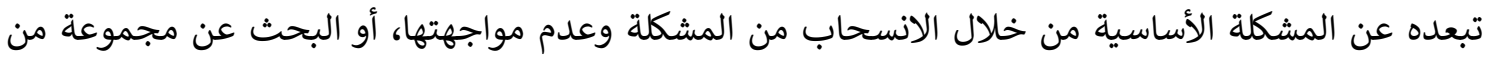

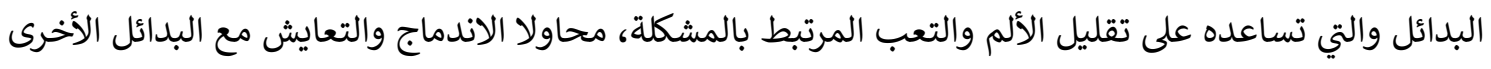

حتى يجد فرصة لحلها. المحور الثالث: الإرشاد المعرفي المريا. تعريف الإرشاد المعرفي السلوكي:

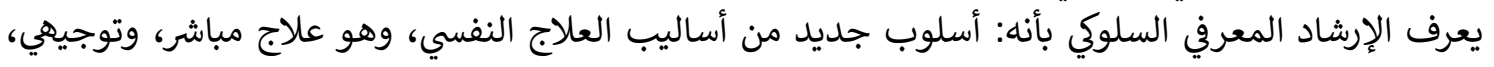

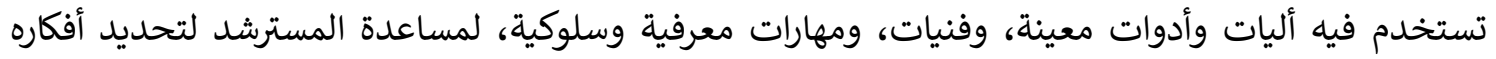

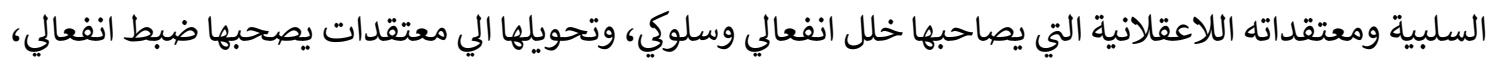

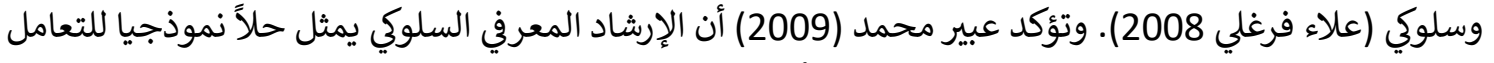

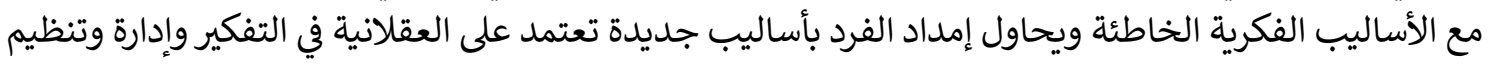

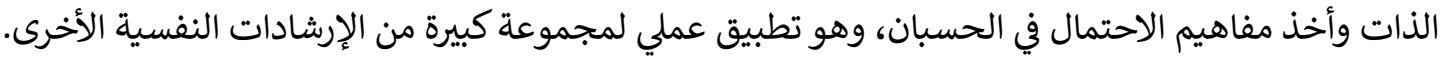

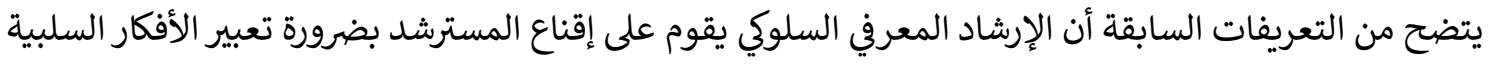

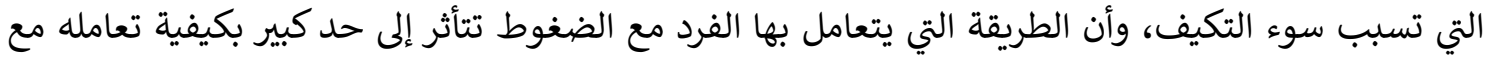

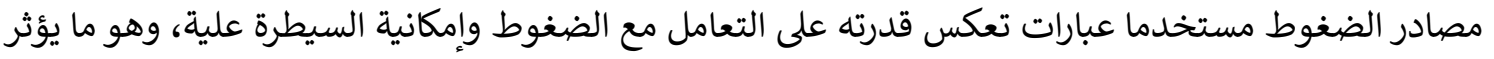
على سلوكه.

\section{أهداف الإرشاد المعرفي السلوكي:}

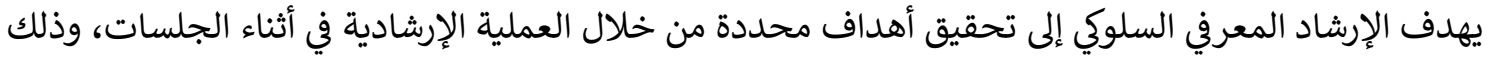

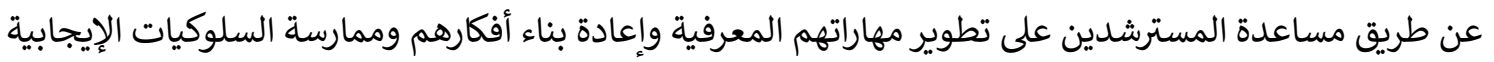

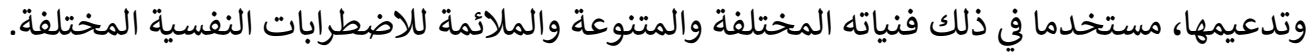

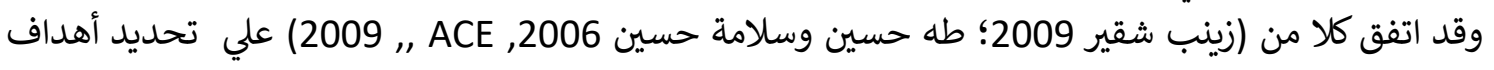

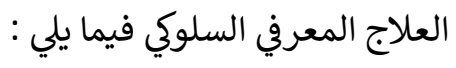
1-يوجه الإرشاد المعرفي السلوكي المسترشد إلى التعرف على المانى الأفكار والاعتقادات غير الفعالة وكيف يقومها

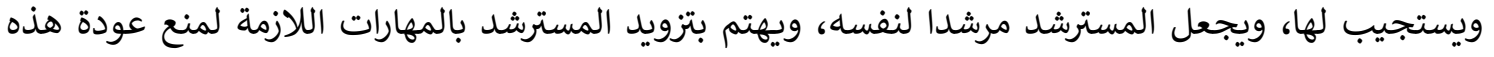

$$
\text { الاضطرابات بعد التخلص منها. }
$$


2-مساعدة المسترشد على إعادة بناء أفكاره، ورؤية حياته ومشكلاته من خلال منظور واقعي، وتشجيع التفكير الصحيح والمنطقي. 3-التركيز على الاهتمام بالوعي في تكوين الخبرة الشخصية للمسترشد.

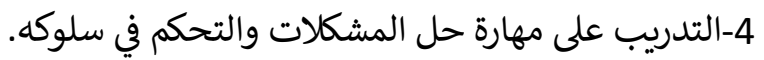

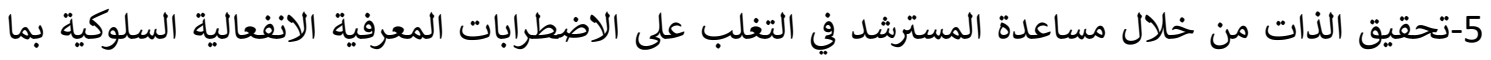

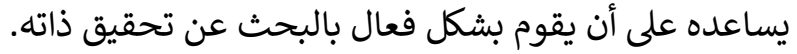

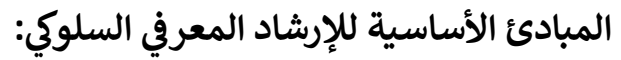

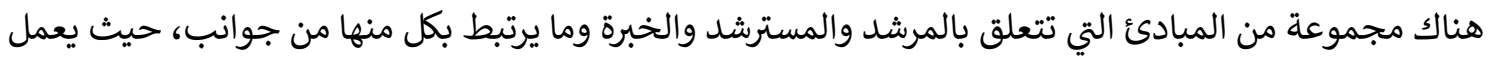

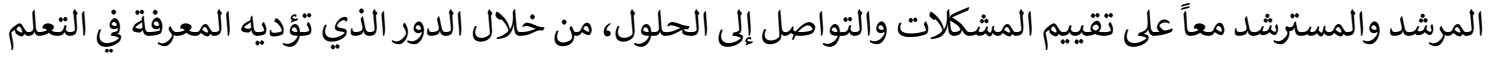

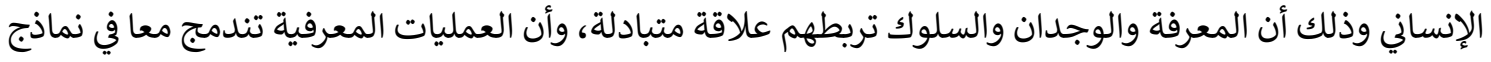
سلوكية، وهذه المبادئ كما ذكرها حامد الغامدي (2010) وهبه السيد السيد (2012) ومحمود صابر وابر (2012) وهدير

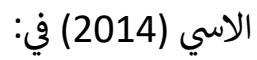
1-العلاقة الإرشادية: يعتبر العنصر الأساسي في نجاح العملية الإرشادية هو بناء علاقة إيجابية بين المرشد 2-المصداقية: يعتبر مدخل تأسيس المصداقية من الأمور الهامة، حيث يتم توصيل رسالة إلى المسترشد مفادها

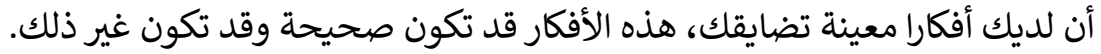

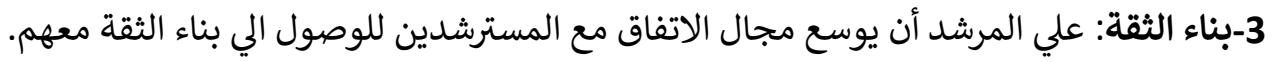

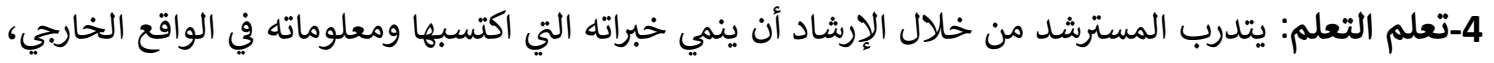

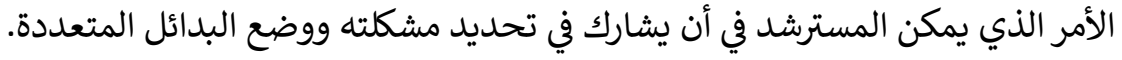

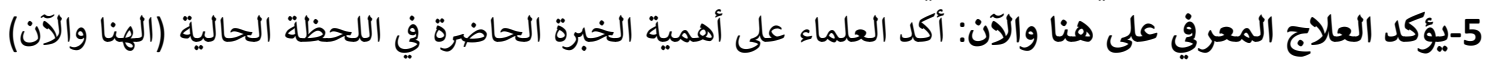

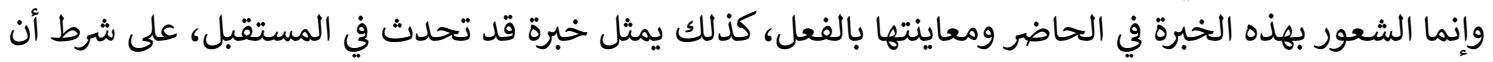

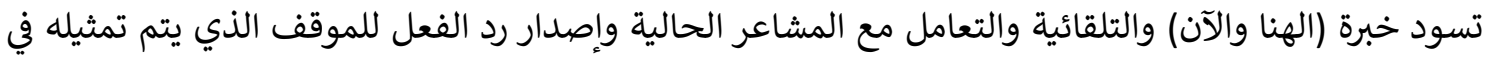

نفس اللحظة.

استخدامات الإرشاد المعرفي السلوكي: المعادي:

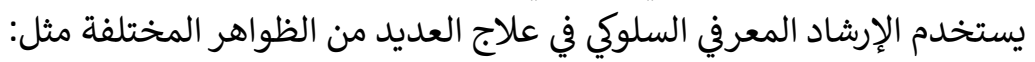

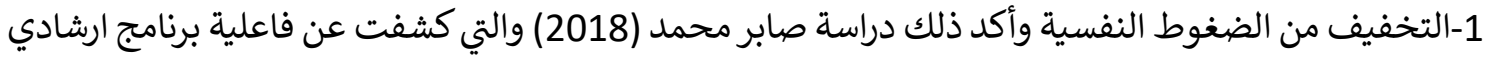

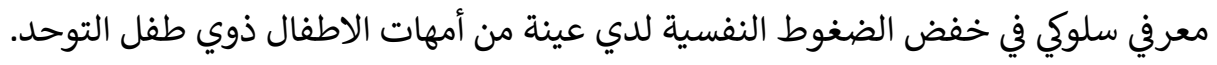

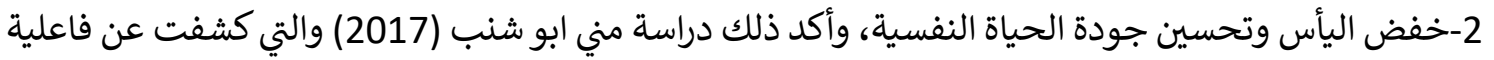

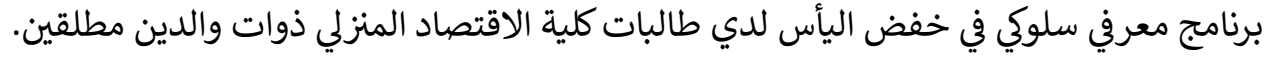

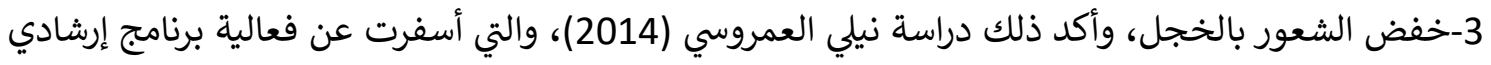
نفسي (معرفي سلوكي) في خفض الشعور بالخجل لدي والدينة دئة دن الطالبات الموهوبات. 
4-خفض مستوي القلق، وأكد ذلك دراسة أنور العمري (2011) والتي أسفرت عن فعالية برنامج إرشادي معرفي سلوكي في خفض مستوي القلق لدي التلاميذ الأيتام.

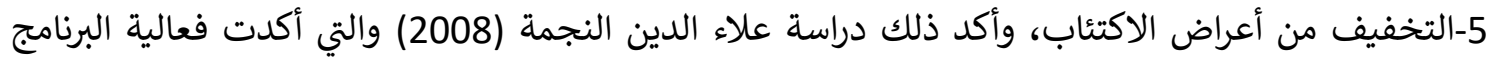

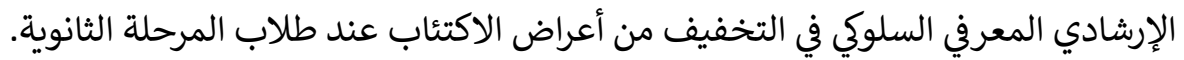
فنيات الإرشاد المعرفي السلوكي:

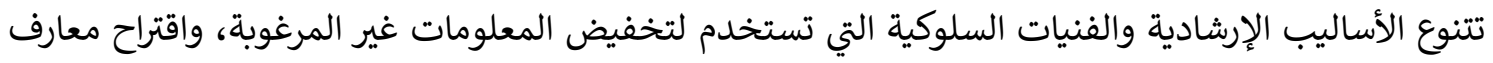

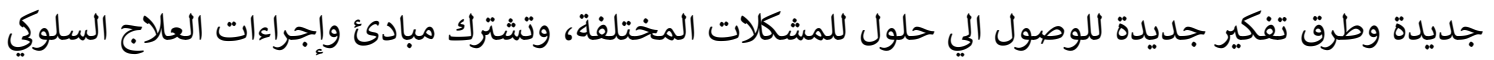

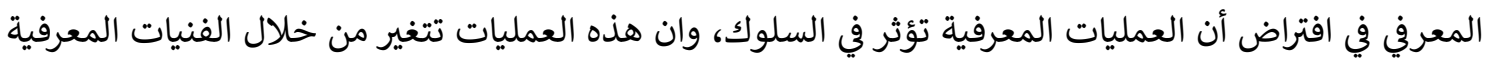

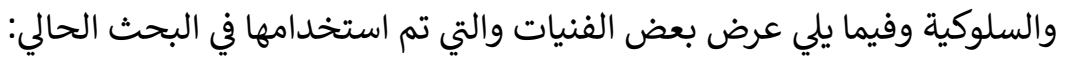

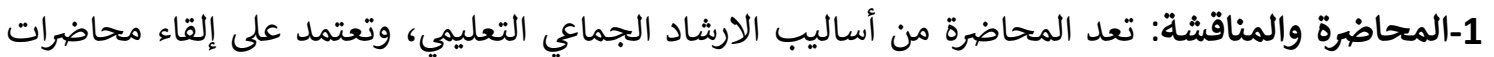

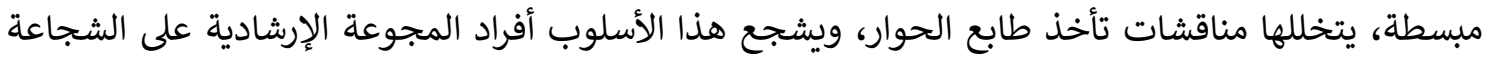

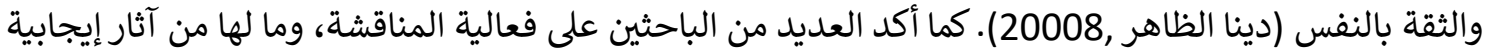

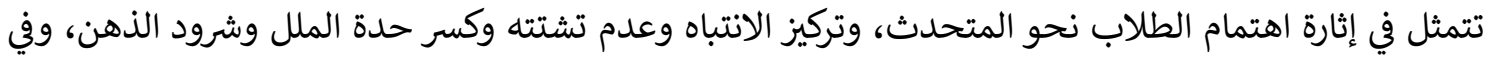

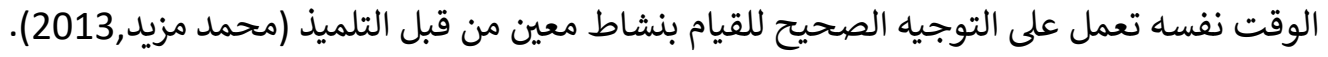
2-تغيير القواعد: أكدت أمل فوزي ومحمود عزب (2014) أن تغيير القواعد يساعد المسترشدين على على استبل التبدال

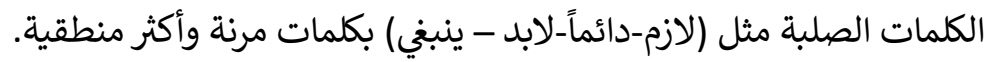

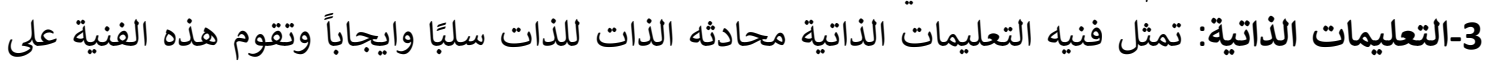

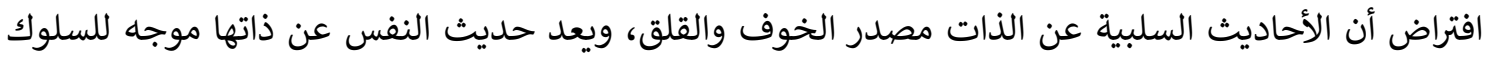

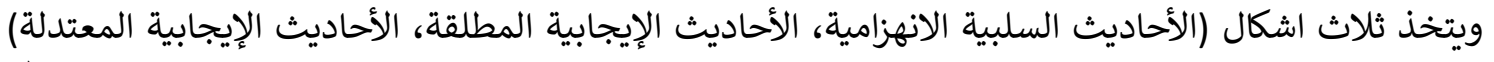

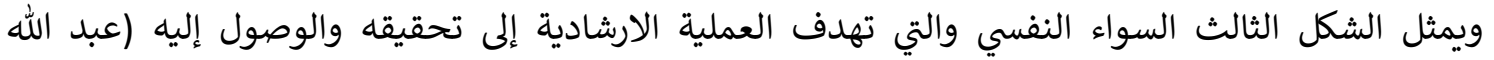

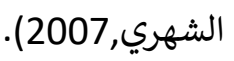
4-الاسترخاء بالتنفس العميق: الاسترخاء أحد الفنيات السلوكية التي تستخدم في كثير من التدخلات الارشادية

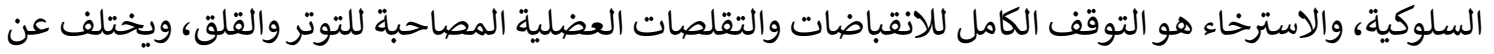

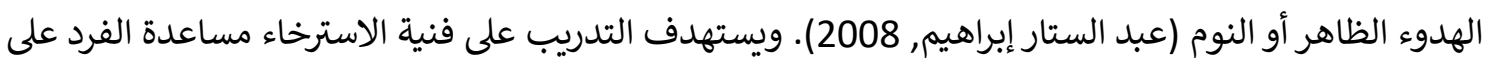

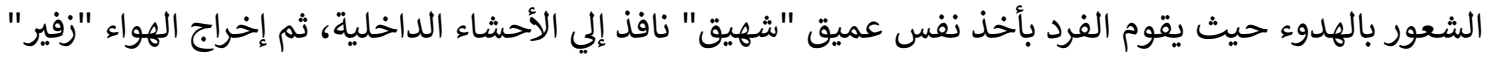

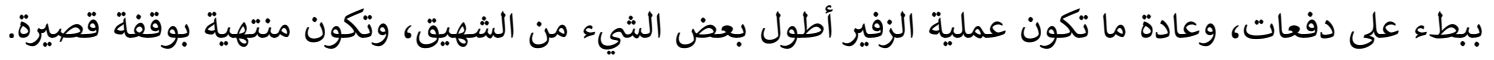

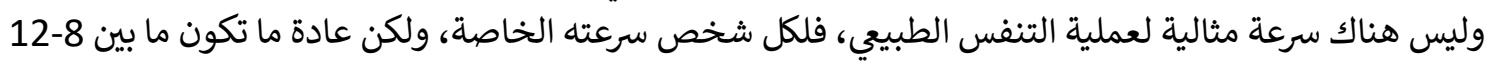
نفس في الدقيقة (روبين داينز, 2006)

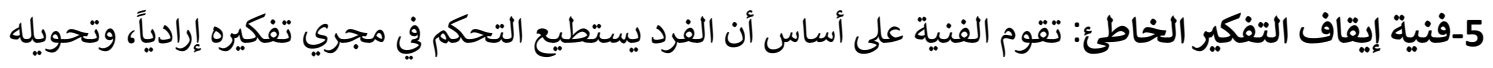

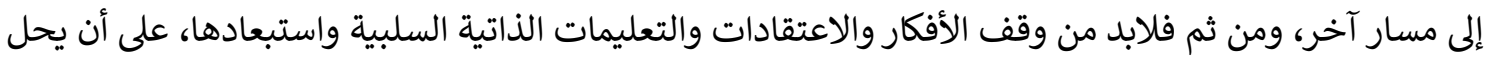

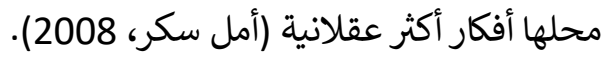


6-إعادة البناء المعرفي: أكد كلا من سليمان سيد أحمد(2010) ورحاب عبد الرحيم ( 2013) علي أن هذه الفنية

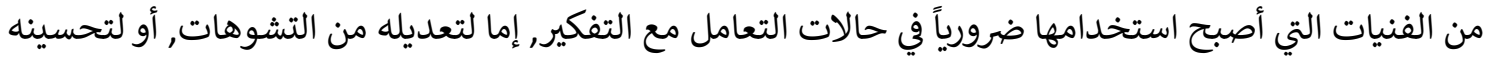

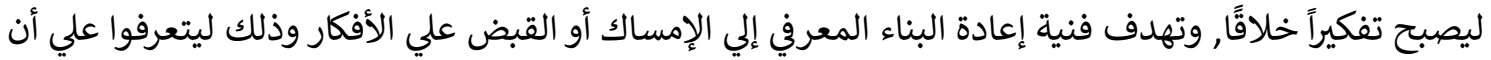

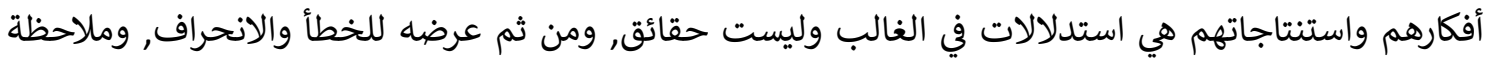
الطريقة التي يتبعوها في التفكير في الموقف الضاغطاتئ وفي تلك المرحلة يتم استبدال العبارات المطلقة لدئ لدي العميل

وتحويلها إلي عبارات نسبية.

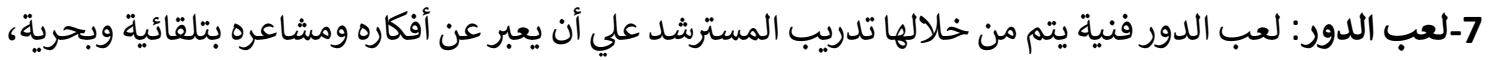

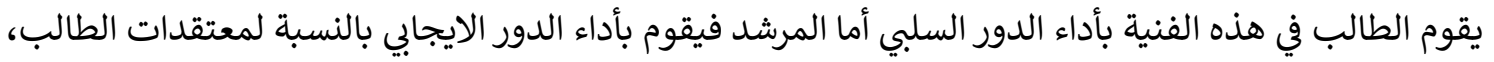

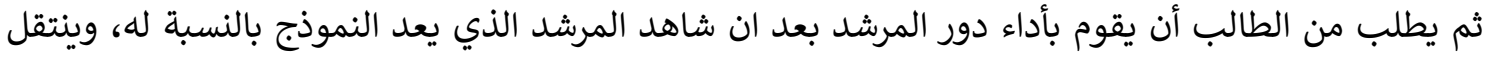
المرشد بين مقعدين يقوم بأداء الدور وعكسه بعد ذلك دلك يقوم الطالب بنفس الشيء (بيرني كورين وبيتر ودول,

8-التدريب على مهارات حل المشكلات: تستخدم هذه الفنية في مختلف المواقف، للوقاية من الضغوط ومعرفة

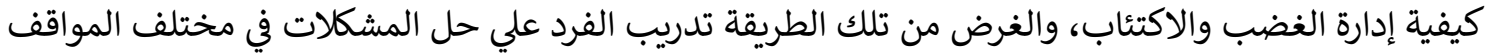

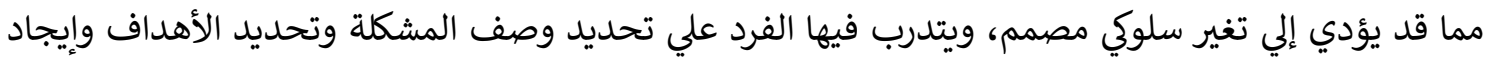

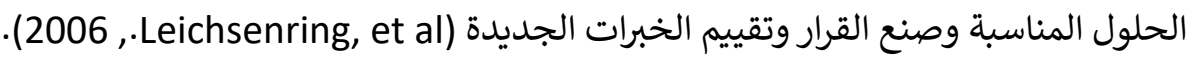
9-القراءة الموجهة: وتعني توجيه المسترشد وتشجيعه على قراءة نوعية معينة من الكتب، او المطبوعات المبرات التي يري المرشد انها ستفيده (معتز عبيد , 2014).

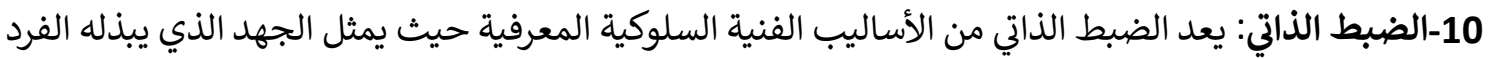

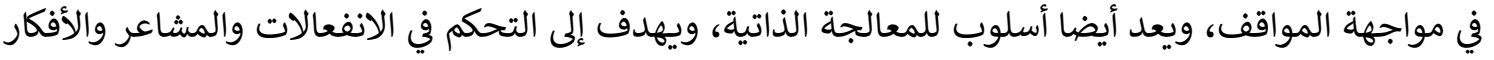

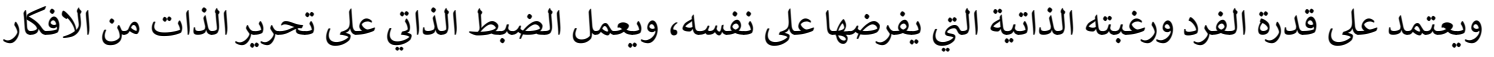

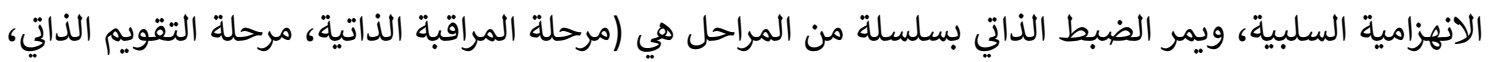
مرحلة التعزيز الذاتي) (عبد الله الشهري , (2007).

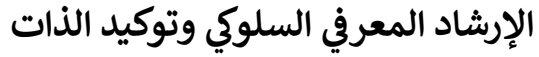
أكدت العديد من الدراسات فاعلية الإرشاد المعرفي السلوكي في تنمية توكيد الذات، ومن تلكيلك الدراسات الدات، درات دراسة

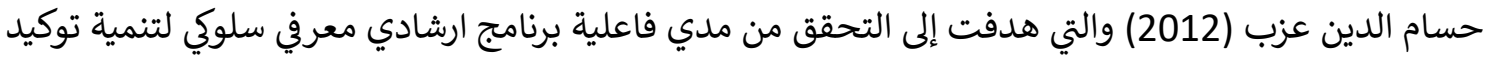

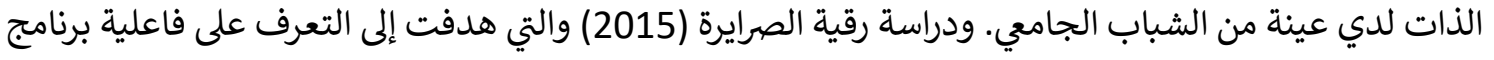

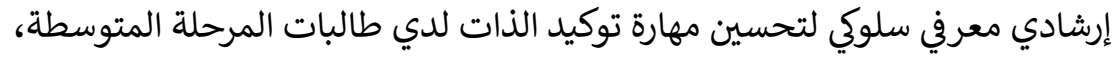
فروض البحث:

في ضوء مشكلة البحث ومن خلال الإطار النظري والدراسات السابقة تم تحديد فروض البحث كالآتي:

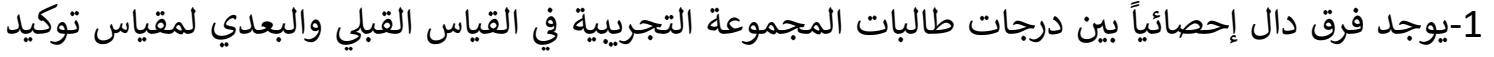
الذات لصالح التطبيق البعدي. 
2-يوجد فرق دال إحصائيا بين درجات طالبات المجموعة التجريبية في القياس القبلي والبعدي لمقياس أساليب مواجهة الضغوط لصالح التطبيق البعدي. 3-لا يوجد فرق دال إحصائيا بين درجات طالبات المجموعة التجريبية في القياس البعدي والتتبعي لمقياس توكيد الذات. 4-لايوجد فرق دال إحصائيا بين درجات طالبات المجموعة التجريبية في القياس البعدي والتتبعي لمقياس أساليب مواجهة الضغوط.

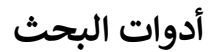
تم استخدام مجموعة من الأدوات لجمع البيانات اللازمة للتحقق من أهداف البحث وفروضه، وقد أجملت

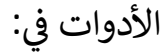
• مقياس توكيد الذات (إعداد الباحثة).

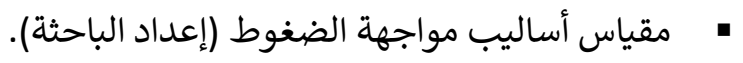
• البرنامج الإرشادي المعرفي السلوكي (إعداد الباحثة).

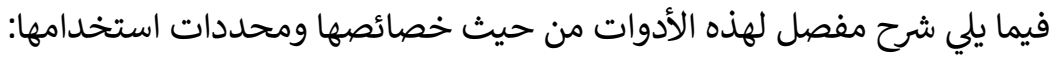
أولا: مقياس توكيد الذات (اعداد الباحثة):

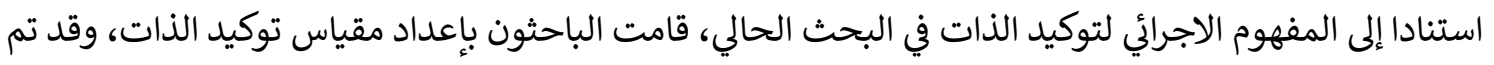
بناء المقياس وفقاً للخطوات التالية: 1-الهدف من المقياس: التعرف على مدفى المقات امتلاك الطالبات المقات لمهارات توكيد الذات.

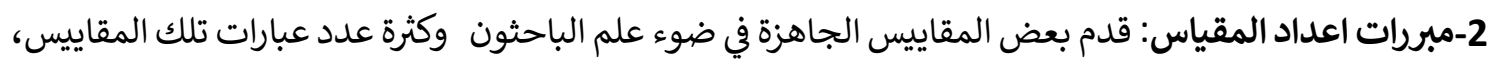

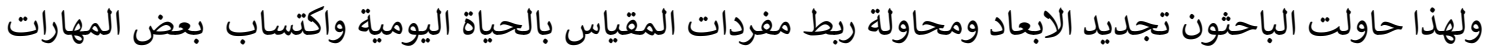

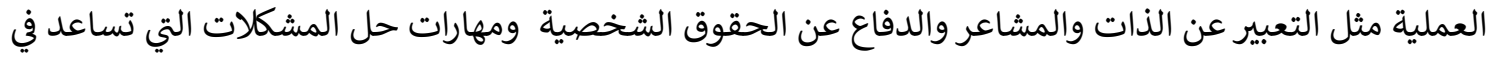
تنمية توكيد الذات لديهم.

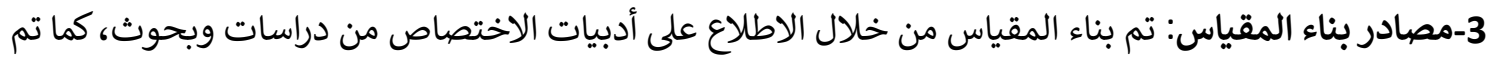

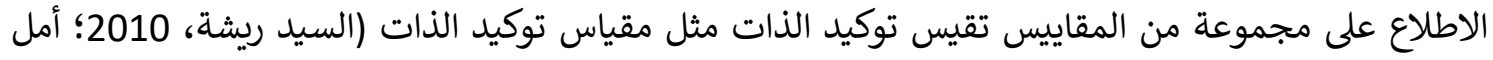

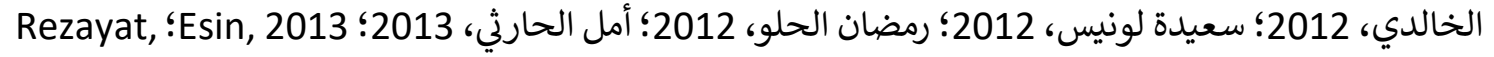

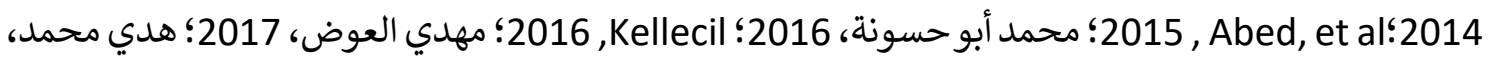

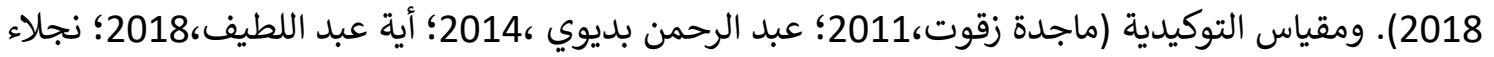

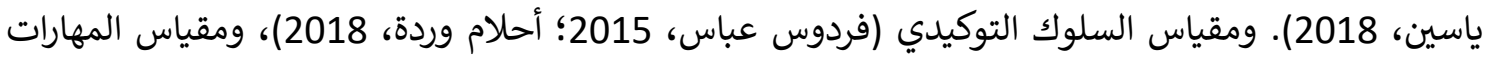

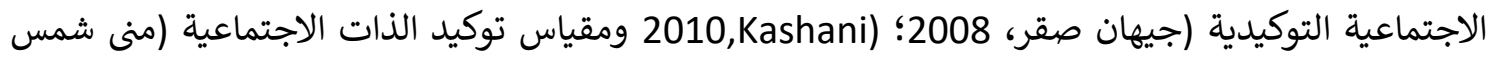
4-اعداد المقياس في صورته الأولية: في ضوء ما تقدم قامت الباحثون بإعداد المقياس وفق الأساليب العلمية

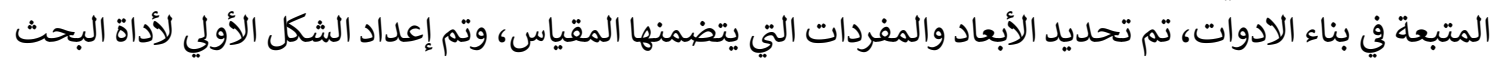


وتكون في الصورة الأولية من (62) عبارة. ولتقدير درجات المقياس فقد أعطت الباحثون لكل مفردة خمس

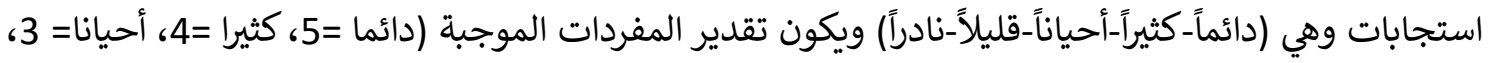
قليلا=2، نادرا=1) وتصحح المفردات السالبة عكس المفردات الموجبة، وتكون الدرجة الكلية مجموع الدرجات

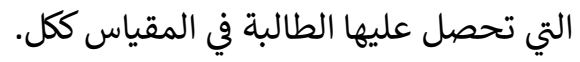
التحقق من الخصائص السيكومترية لمقياس توكيد الذات:

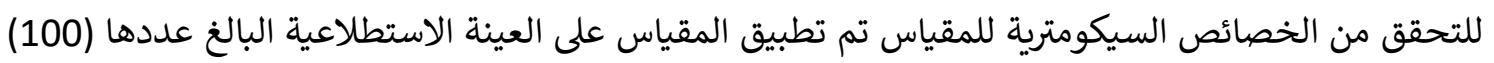

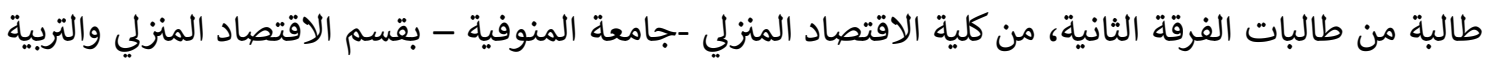

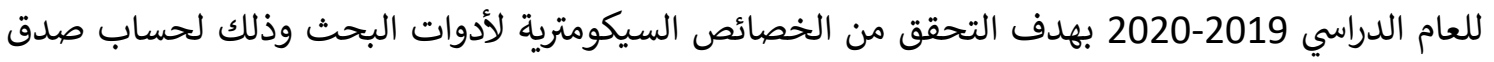
وثبات المقياس.

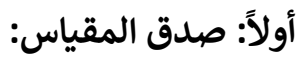
للتحقق من صدق المقياس استخدمت الباحثون الطرق التالية: - مداق المحكمين قامت الباحثون بعرض المقياس على عدد من المحكمين وذوي الاختصاص في مجال علم النفس والإرشاد النفسي

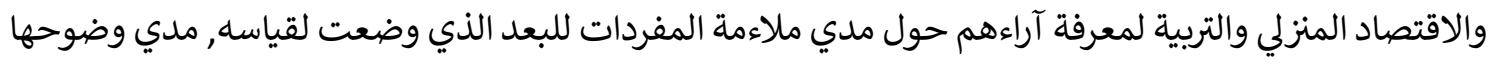

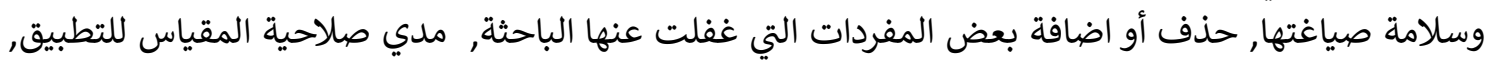

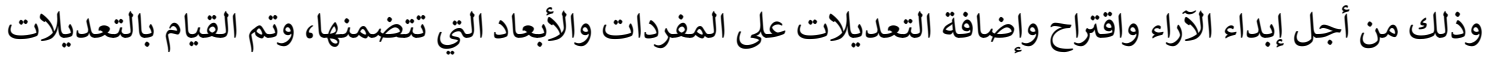

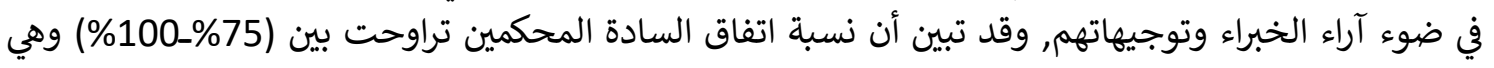

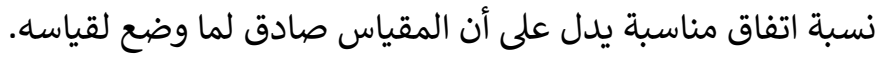

الاتساق الداخلي:

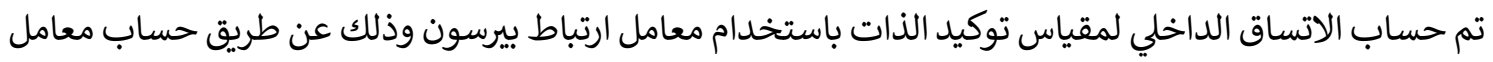

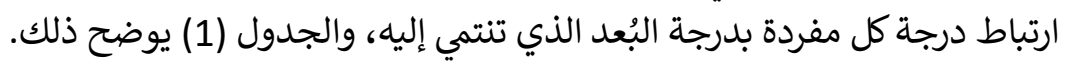

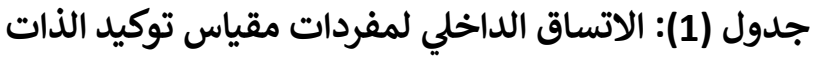

\begin{tabular}{|c|c|c|c|c|c|c|c|c|c|c|c|}
\hline \multirow{2}{*}{\multicolumn{2}{|c|}{ أل البناء المعرفي }} & \multicolumn{2}{|c|}{ التواصل مع الآخرين } & \multicolumn{2}{|c|}{ الاجتماعسارة } & \multicolumn{2}{|l|}{ التعبير عن المشاعر } & \multicolumn{2}{|c|}{ التعبير عن الذات } & \multicolumn{2}{|c|}{ الوعي بالحقوق التوكيدية } \\
\hline & & بدرجة البُعد & $\hat{r}$ & بدرجة البُعد & r & بدرجة البُعد & r & بدرجة البُعد & & بدرجة البُعد & p \\
\hline $0,43^{* *}$ & 1 & $0,39^{* *}$ & 1 & $0,40^{* *}$ & 1 & $0,41^{* *}$ & 1 & $0,46^{* *}$ & 1 & $0,44^{* *}$ & 1 \\
\hline $0,51^{* *}$ & 2 & $0,43^{* *}$ & 2 & $0,37^{* *}$ & 2 & $0,45^{* *}$ & 2 & $0,46^{* *}$ & 2 & $0,66^{* *}$ & 2 \\
\hline $0,21^{*}$ & 3 & $0,43^{* *}$ & 3 & $0,59^{* *}$ & 3 & $0,32^{* *}$ & 3 & $0,47^{* *}$ & 3 & $0,43^{* *}$ & 3 \\
\hline $0,35^{* *}$ & 4 & $0,38^{* *}$ & 4 & $0,23^{*}$ & 4 & $0,24^{*}$ & 4 & $0,36^{* *}$ & 4 & $0,44^{* *}$ & 4 \\
\hline $0,52^{* *}$ & 5 & $0,33^{* *}$ & 5 & $0,43^{* *}$ & 5 & $0,35^{* *}$ & 5 & $0,49^{* *}$ & 5 & $0,51^{* *}$ & 5 \\
\hline $0,54^{* *}$ & 6 & $0,52^{* *}$ & 6 & $0,38^{* *}$ & 6 & $0,54^{* *}$ & 6 & $0,54^{* *}$ & 6 & $0,44^{* *}$ & 6 \\
\hline
\end{tabular}

JHE, 2021, 31(2): pp 267-308 . يتم طباعتها في جامعة المنوفية، جميع حقوق الطبع محفوظة للمجلة. 


\begin{tabular}{|c|c|c|c|c|c|c|c|c|c|c|c|}
\hline \multicolumn{2}{|c|}{ البناء المعرفي } & \multicolumn{2}{|c|}{ التواصل مع الآخرين } & \multicolumn{2}{|c|}{ الاجتماعية } & \multicolumn{2}{|c|}{ التعبير عن المشاعر } & \multicolumn{2}{|c|}{ التعبير عن الذات } & \multicolumn{2}{|c|}{ الوعي بالحقوق التوكيدية } \\
\hline بدرجة البُعد & $\hat{r}$ & بدرجة البُعد & $\hat{P}$ & بدرجة البُعد & $\hat{r}$ & بدرجة البُعد & $\hat{r}$ & بدرجة البُعد & r & بدرجة البُعد & p \\
\hline $0,42^{* *}$ & 7 & $0,24^{*}$ & 7 & $0,39^{* *}$ & 7 & $0,38^{* *}$ & 7 & $0,41^{* *}$ & 7 & $0,43^{* *}$ & 7 \\
\hline $0,49^{* *}$ & 8 & $0,36^{* *}$ & 8 & $0,50^{* *}$ & 8 & $0,37^{* *}$ & 8 & $0,49^{* *}$ & 8 & $0,42^{* *}$ & 8 \\
\hline $0,38^{* *}$ & 9 & $0,48^{* *}$ & 9 & $0,51^{* *}$ & 9 & $0,38^{* *}$ & 9 & $0,56^{* *}$ & 9 & $0,32^{* *}$ & 9 \\
\hline $0,42^{* *}$ & 10 & $0,50^{* *}$ & 10 & $0,49^{* *}$ & 10 & & & $0,35^{* *}$ & 10 & & \\
\hline $0,43^{* *}$ & 11 & $0,56^{* *}$ & 11 & $0,51^{* *}$ & 11 & & & & & & \\
\hline & & & & $0,43^{* *}$ & 12 & & & & & & \\
\hline
\end{tabular}
* * إحصائيا عند مستوى 0,01 * دال عند مستوي 0,05 إنجري

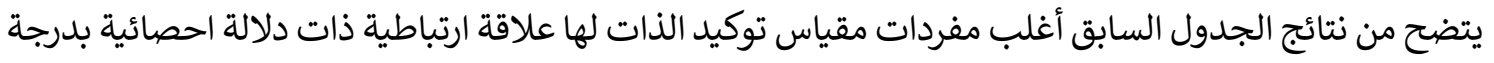

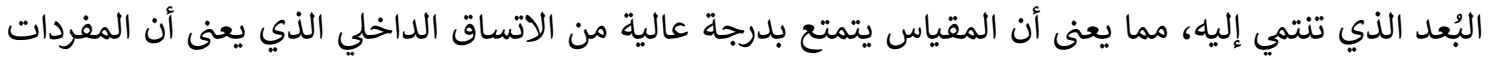

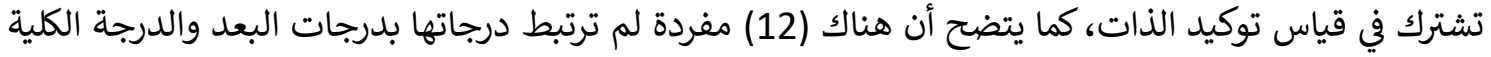

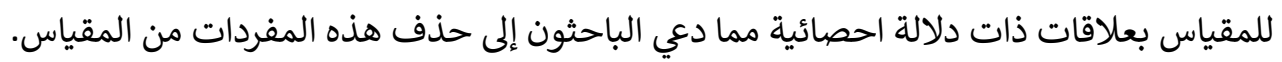

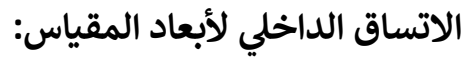
تم حساب الاتساق الداخلي لأبعاد المقياس من خلال الإل حساب الداب معامل الارتباط بين أبعاد المقياس والدرجة الكلية

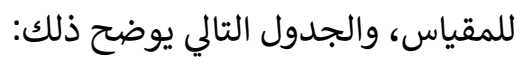
جدول (2): معاملات الارتباط بين أبعاد مقياس توكيد الذات والدورلي الدرة الكلية للأبعاد

\begin{tabular}{|c|c|c|}
\hline معامل الارتباط بالمقياس ككل & 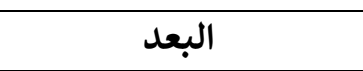 & b \\
\hline $0,633^{* *}$ & الوعي بالحقوق التوكيدية & 1 \\
\hline $0,688^{* *}$ & التعبير عن الذات & 2 \\
\hline $0,499 * *$ & التعبير عن المشاعر & 3 \\
\hline $0,762 * *$ & الجسارة الاجتماعية & 4 \\
\hline $0,639 * *$ & التواصل مع الآخرين & 5 \\
\hline $0,560 * *$ & البناء المعرفي & 6 \\
\hline
\end{tabular}

يتضح من الجدول السابق أن جميع معاملات الارتباط بين كل بعد من الأبعاد والدرجة الكلية للأبعاد دالة عند الداء

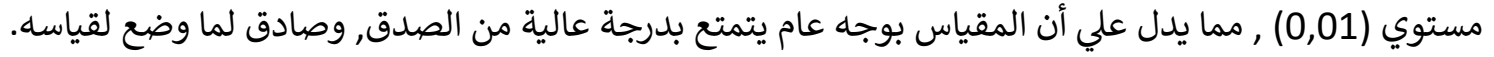
ثانياً: ثبات مقياس توكيد الذات تم حساب درجة ثبات المقياس بطريقتين همات الدات (ألفاكرونباخ -التجزئة النصفية). أ- ثبات المقياس باستخدام طريقة ألفاكرونباخ 
تم حساب الثبات بطريقة ألفا كرونباخ، حيث تم حساب ثبات أبعاد المقياس الفرعية والمقياس ككل، ويوضح

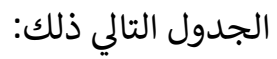

جدول (3): معامل ثبات مقياس توكيد الذات بطريقة ألفا كرونباخ

\begin{tabular}{|c|c|c|}
\hline معامل ألفاكرونباخ & البعد & b \\
\hline 0,861 & الوعي بالحقوق التوكيدية & 1 \\
\hline 0,847 & التعبير عن الذات & 2 \\
\hline 0,813 & التعبير عن المشاعر & 3 \\
\hline 0,866 & الجسارة الاجتماعية & 4 \\
\hline 0,851 & التواصل مع الآخرين & 5 \\
\hline 0,855 & البناء المعرفي & 6 \\
\hline 0,852 & المقياس ككل & \\
\hline
\end{tabular}

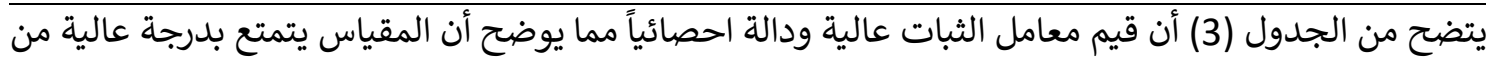
الثبات تطمئن الباحثون إلى تطبيقه على الثيات العينة الأساسية.

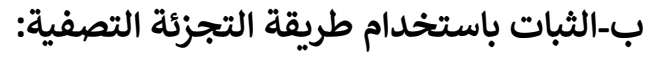

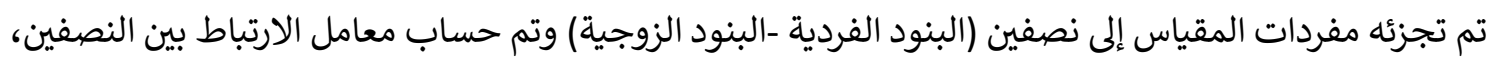

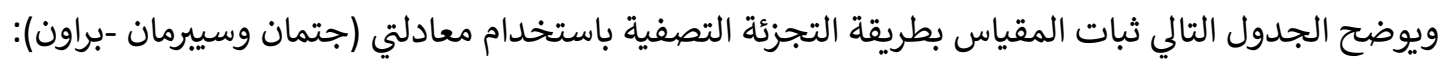
جدول (4): ثبات المقياس بطريقة التجزئة النصفية باستخدام معادلتي جتمان وسئنيات وسيبرمان -براون

\begin{tabular}{|c|c|c|}
\hline معادلة سييرمان براون & معادلة جتمان & مقياس \\
\hline 0,665 & 0,665 & مقياس توكيد الذات \\
\hline
\end{tabular}

يتضح من الجدول (4) أن قيم معامل الثبات عالية ودالة احصائياً مما يدل على أن المقياس يتمتع بدرجة عالية من الثبات تطمئن الباحثون إلى تطبيقه على العيم العينة الأساسية.

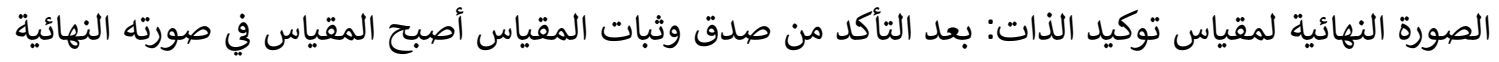

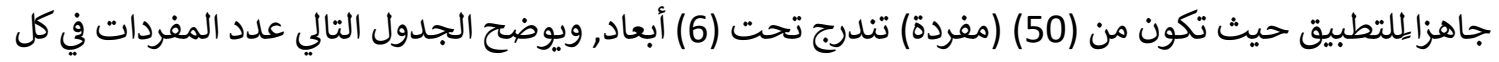

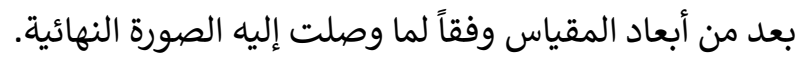

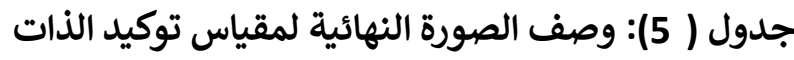

\begin{tabular}{|c|c|c|c|}
\hline المجموع & أرقام المفردات & 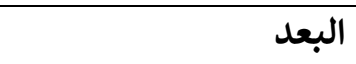 & 5 \\
\hline 6 & $6,12,21^{*}, 30,43,47$ & الوعي بالحقوق التوكيدية & 1 \\
\hline 9 & $5,13,22,31^{*}, 32,33,41,46,48$ & التعبير عن الذات & 2 \\
\hline 6 & $4,14,23^{*}, 38,42^{*}, 45$ & التعبير عن المشاعر & 3 \\
\hline 11 & $1,7,11,15^{*}, 16,24^{*}, 26,34,37^{*}, 39,50$ & الجسارة الاجتماعية & 4 \\
\hline 9 & $2,8,19,20^{*}, 29^{*}, 36,44,49$ & التواصل مع الآخرين & 5 \\
\hline
\end{tabular}

JHE, 2021, 31(2): pp 267-308 . يتم طباعتها في جامعة المنوفية، جميع حقوق الطبع محفوظة للمجلة. 


\begin{tabular}{crr}
\hline م & البعاء المعرفي
\end{tabular}
50

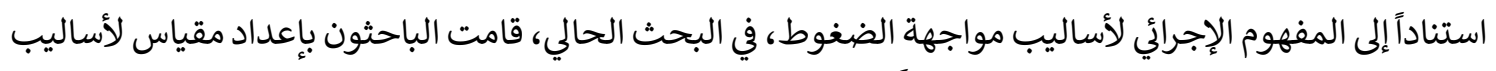

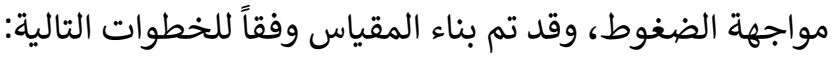

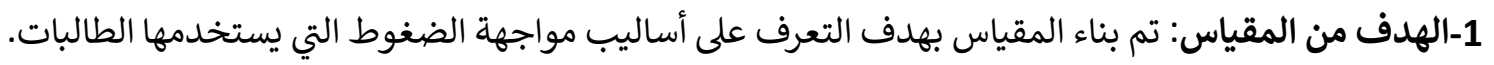

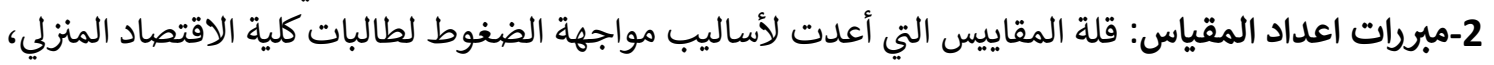

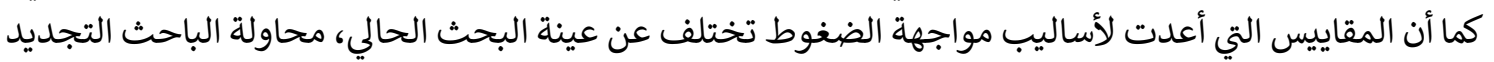

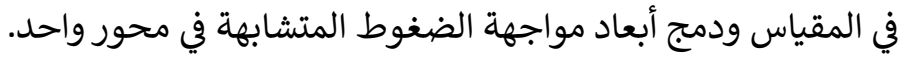

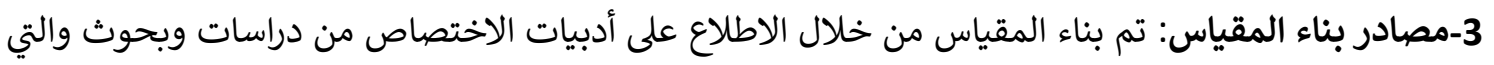

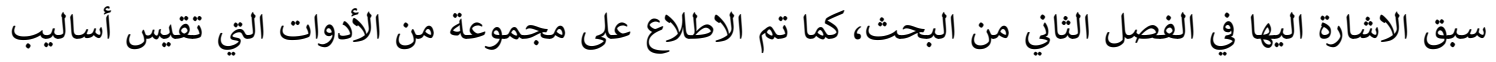

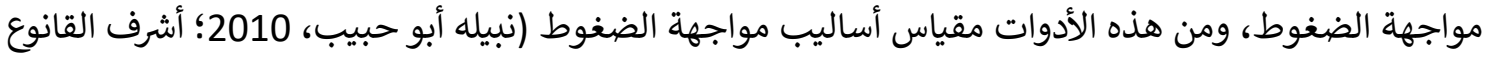

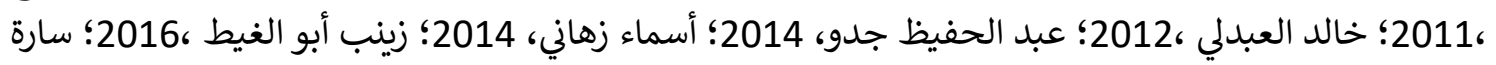

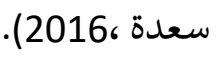
4-اعداد المقياس في صورته الأولية: في ضوء ما تقدم قامت الباحثون بإعداد المقياس وفق الأساليب العلمية

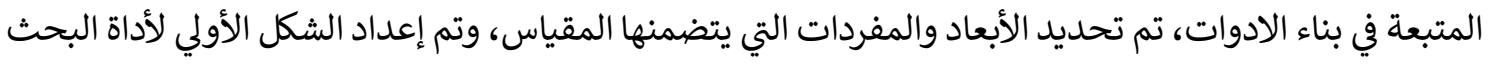

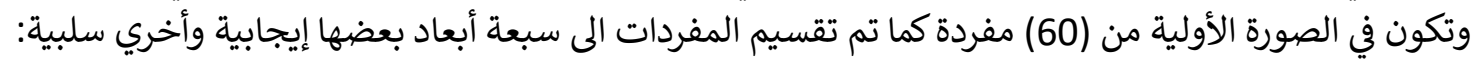

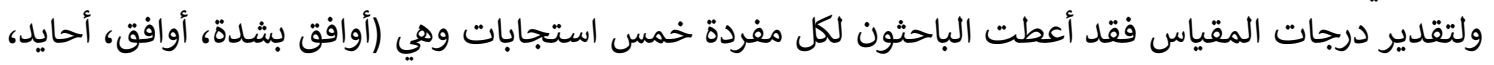

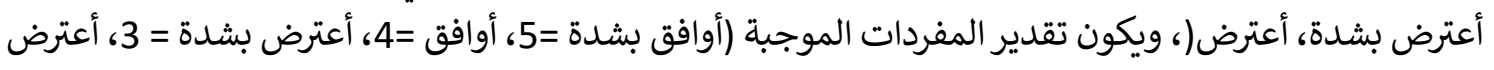

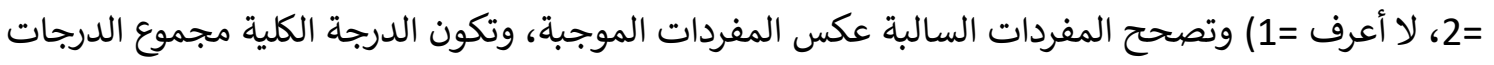
التي تحصل عليها الطالبة في المقياس كلئ المغردات السالية

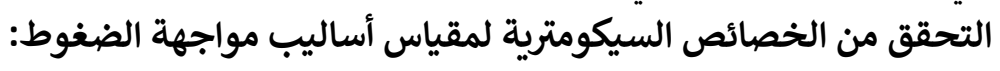

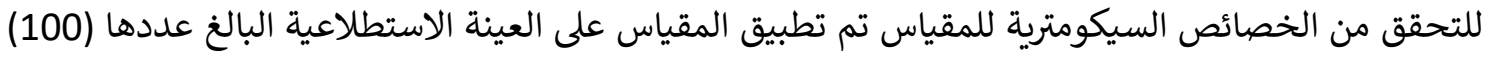

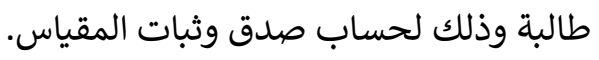

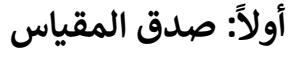
للتحقق من صدق المقياس استخدمت الباحثون الطرق التالية: صدق المحكمين قامت الباحثون بعرض المقياس على عدد من المحكمين وذوي الاختصاص في مجال علم المئن النفس والإرشاد النفسي

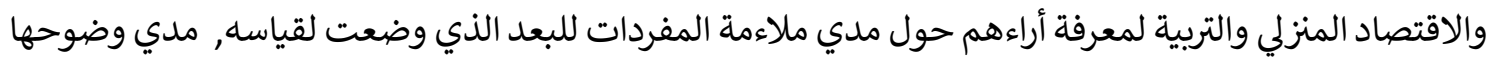

JHE, 2021, 31(2): pp 267-308 . يتم طباعتها في جامعة المنوفية، جميع حقوق الطبع محفوظة للمجلة. 
وسلامة صياغتها, حذف أو اضافة بعض المفردات التي غفلت عنها الباحثة, مدي صلاحية المقياس للتطبيق,

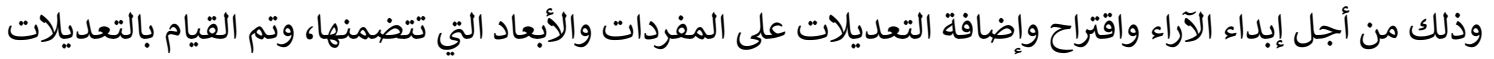

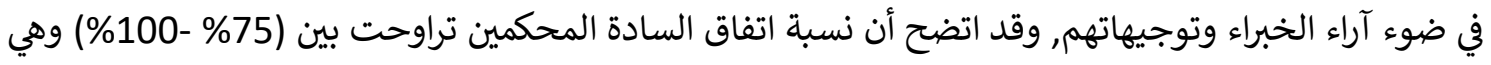

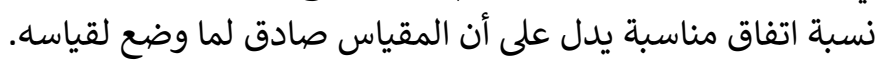

الاتساق الداخلي: تم حساب الاتساق الداخلي لمقياس أساليب مواجهة الضغوط الضافئ بحساب معامل ارتباط بيرسون وذلك عن طريق

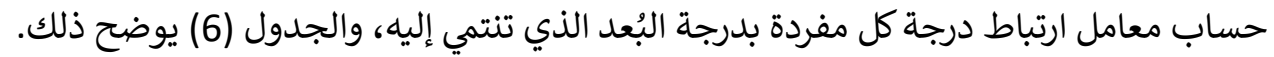

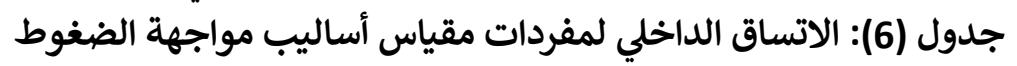

\begin{tabular}{|c|c|c|c|c|c|c|c|c|c|c|c|c|c|}
\hline \multicolumn{2}{|c|}{ والبحث عن الإثابات } & \multicolumn{2}{|c|}{ للمشكلة وتقبام الاستسلام } & \multicolumn{2}{|c|}{ إعادة التفسير } & \multicolumn{2}{|c|}{ والتصدي لهاكلة } & \multicolumn{2}{|c|}{ البحث عن المعلومات } & \multicolumn{2}{|c|}{ المنطقيل } & \multicolumn{2}{|c|}{ المسئولية } \\
\hline 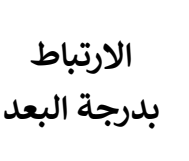 & p & الارتباط & p & الارتباط البُعد & p & الارتباط & p & الارتباط & م & الارتباط & & الارتباط & p \\
\hline $0,43 * *$ & 1 & $0,27 * *$ & 1 & $0,39 * *$ & 1 & $0,48^{* *}$ & 1 & $0,44^{* *}$ & 1 & $0,51^{* *}$ & & 0,18 & 1 \\
\hline $0,55^{* *}$ & 2 & $0,39 * *$ & 2 & $0,30 * *$ & 2 & $0,47^{* *}$ & 2 & $0,53^{* *}$ & 2 & $0,47^{* *}$ & 2 & $0,58^{* *}$ & 2 \\
\hline $0,55 * *$ & 3 & $0,32 * *$ & 3 & $0,49 * *$ & 3 & $0,54^{* *}$ & 3 & $0,39^{* *}$ & 3 & $0,48^{* *}$ & 3 & $0,61^{* *}$ & 3 \\
\hline $0,49 * *$ & 4 & k* & 4 & $0,38 * *$ & 4 & $0,53^{* *}$ & 4 & $0,69^{* *}$ & 4 & $0,49^{* *}$ & & $0,66^{* *}$ & 4 \\
\hline $0,43 * *$ & 5 & $0,52 * *$ & 5 & $0,48^{* *}$ & 5 & $0,41^{* *}$ & 5 & $0,55^{* *}$ & 5 & $0,49^{* *}$ & & $0,77^{* *}$ & 5 \\
\hline $0,29 * *$ & 6 & $*$ & 6 & $0,39 * *$ & 6 & $0,55^{* *}$ & 6 & $0,41^{* *}$ & 6 & $0,53^{* *}$ & & $0,74^{* *}$ & \\
\hline $0,42 * *$ & 7 & $0,42 * *$ & 7 & $0,49 * *$ & 7 & $0,49^{* *}$ & 7 & $0,61^{* *}$ & 7 & $0,39^{* *}$ & & $0,69^{* *}$ & 7 \\
\hline $0,49 * *$ & 8 & $0,49 * *$ & 8 & & & $0,43^{* *}$ & 8 & $0,52^{* *}$ & 8 & $0,45^{* *}$ & & $0,55^{* *}$ & 8 \\
\hline $0,44^{* *}$ & 9 & & & & & $0,46^{* *}$ & 9 & & & & & 0,12 & 9 \\
\hline $0,33 * *$ & 10 & & & & & & & & & & & & \\
\hline $0,49 * *$ & 11 & & & & & & & & & & & & \\
\hline
\end{tabular}

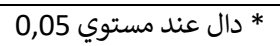
0,01 * احصائيا عند مستوى

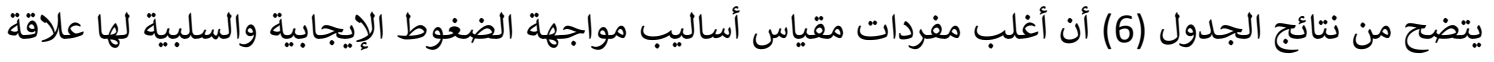

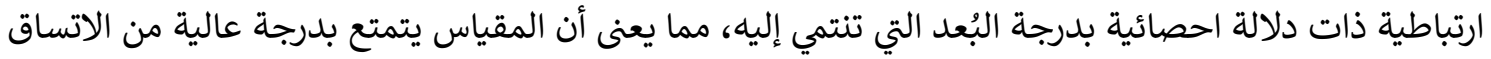

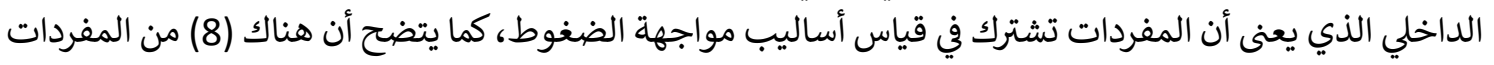

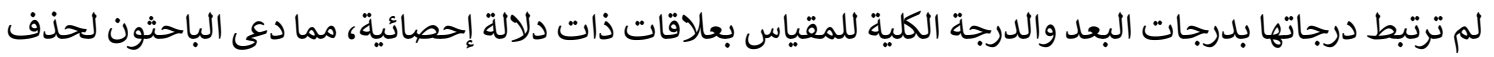
هذه المفردات من المقياس. 
الاتساق الداخلي للأبعاد:

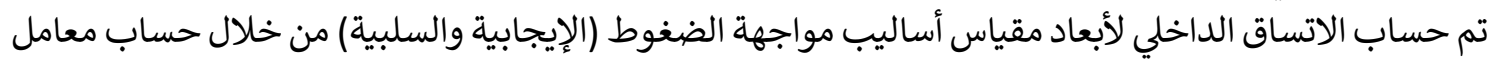

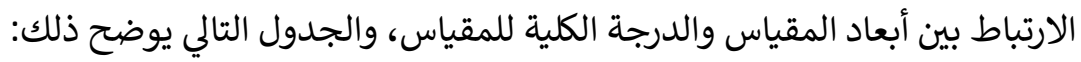

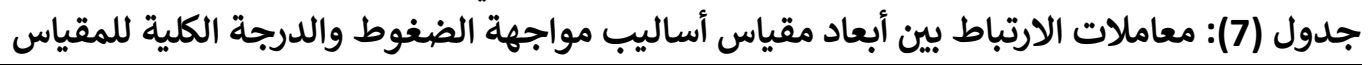

\begin{tabular}{|c|c|c|}
\hline معامل الارتباط بالمقياس ككل & 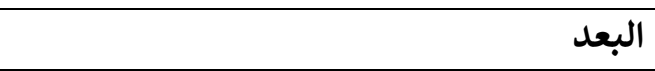 & 5 \\
\hline $0,41^{* *}$ & تحمل المسؤولية & 1 \\
\hline $0,57 * *$ & التحليل المنطقي للمشكلة والتركيز عليها & 2 \\
\hline $0,39 * *$ & البحث عن المعلومات لاتخاذ القرار المناسب & 3 \\
\hline $0,47 * *$ & مواجهة المشكلة والتصدي لها & 4 \\
\hline $0,48^{* *}$ & اعادة التفسير الإيجابي & 5 \\
\hline $0,39 * *$ & الاستسلام للمشكلة وتقبل الامر الواقع & 6 \\
\hline $0,37 * *$ & الانسحاب السلوكي والبحث عن الإثابات البديلة & 7 \\
\hline
\end{tabular}

يتضح من الجدول (7) أن جميع معاملات الارتباط بين كل بعد من أبعاد المقياس والدرجة الكلية للمقياس دالة

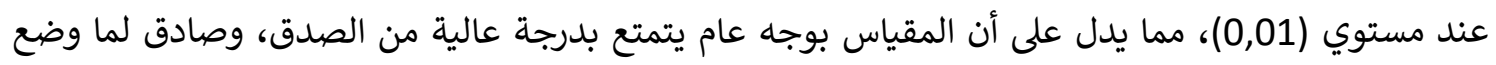

ثانياً: ثبات مقياس أساليب مواجهة الضغوط

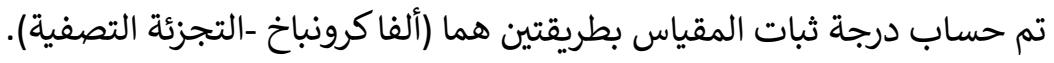

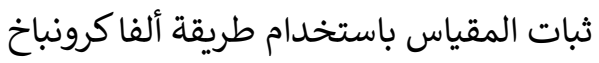

تم حساب الثبات بطريقة ألفا كرونباخ، حيث تم حساب ثبات ثبات أبعاد المقيات المباس الفرعية وحساب ثبات المقياس ككل، ويوضح الجدول التالي ذلك:

جدول (8): معامل ثبات مقياس أساليب مواجهة الضغول دوط بطريقة ألفاكرونباخ

\begin{tabular}{|c|c|c|}
\hline معامل ألفاكرونباخ & 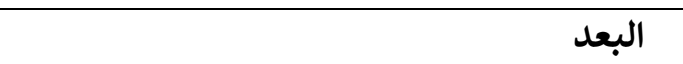 & 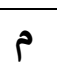 \\
\hline 0,877 & تحمل المسؤولية & 1 \\
\hline 0,880 & التحليل المنطقي للمشكلة والتركيز عليها & 2 \\
\hline 0,893 & البحث عن المعلومات لاتخاذ القرار المناسب & 3 \\
\hline 0,867 & مواجهة المشكلة والتصدي لها & 4 \\
\hline 0,879 & اعادة التفسير الإيجابي & 5 \\
\hline 0,858 & الاستسلام للمشكلة وتقبل الامر الواقع & 6 \\
\hline 0,890 & الانسحاب السلوكي والبحث عن الإثابات البديلة & 7 \\
\hline 0,881 & 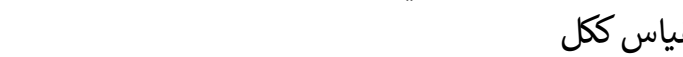 & \\
\hline
\end{tabular}

JHE, 2021, 31(2): pp 267-308 . يتم طباعتها في جامعة المنوفية، جميع حقوق الطبع محفوظة للمجلة. 


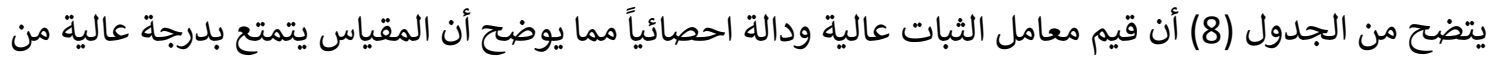
الثبات تطمئن الباحثون إلى تطبيقه على العينة الأساسية.

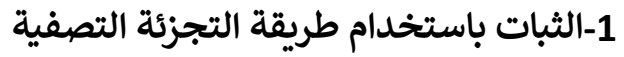

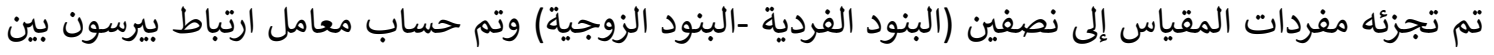

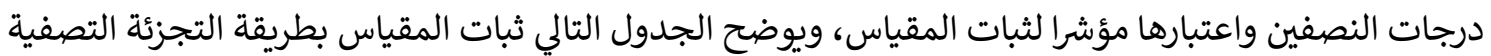

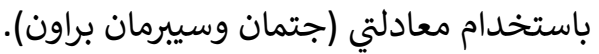

جدول (9): ثبات مقياس أساليب مواجهة الضغوط بطئي بطريقة التجزئة النصفية باستخدام معادلتي جتمان

وبراون

\begin{tabular}{|c|c|c|}
\hline معادلة سبيرمان براون & معادل جتمان & مقياس \\
\hline 0,716 & 0,693 & مقياس أساليب مواجهة الضغوط \\
\hline
\end{tabular}

الصورة النهائية لمقياس أساليب مواجهة الضغوط:

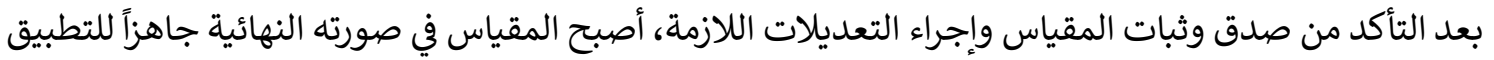

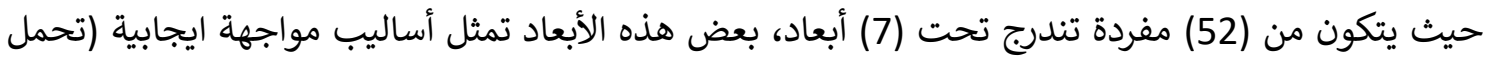

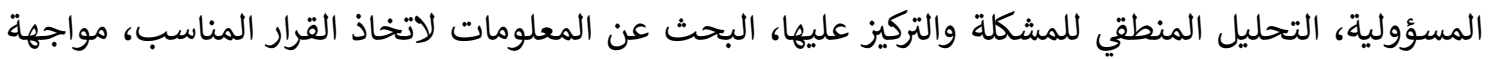

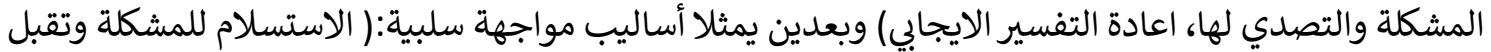

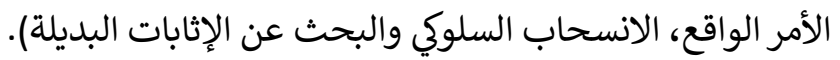

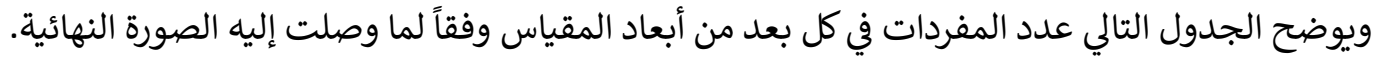

\begin{tabular}{|c|c|c|}
\hline \multicolumn{3}{|c|}{ جدول (10): وصف الصورة النهائية لمقياس اساليب مواجهة الضغوط } \\
\hline 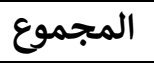 & أرقام المفردات & م البعد \\
\hline 7 & $8,10,22 *, 32,43,44,52$ & 1 تحمل المسؤولية \\
\hline 8 & $9,11,21,23,33,42,45,51$ & 2 التحليل المنطقي للمشكلة والتركيز عليها \\
\hline 8 & $7,12,19,20,31,34,46,50$ & 3 البحث عن المعلومات لاتخاذ القرار المناسب \\
\hline 9 & $5,13,18^{*}, 24,30,35,37,41,47$ & 4 مواجهة المشكلة والتصدي لها \\
\hline 6 & $6,14,25,29,36,48$ & 5 اعادة التفسير الإيجابي \\
\hline 6 & $2 *, 3^{*}, 15^{*}, 28^{*}, 40,49$ & 6 الاستسلام للمشكلة وتقبل الأمر الواقع \\
\hline \multirow[t]{2}{*}{8} & $1^{*}, 4^{*}, 16^{*}, 17^{*}, 26^{*}, 27,38,39^{*}$ & 7 الانسحاب السلوكي والبحث عن الإثابات البديلة \\
\hline & 52 & 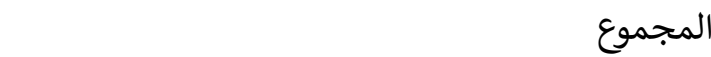 \\
\hline
\end{tabular}

JHE, 2021, 31(2): pp 267-308 . يتم طباعتها في جامعة المنوفية، جميع حقوق الطبع محفوظة للمجلة. 
البرنامج الإرشادي المعرفي السلوكي:

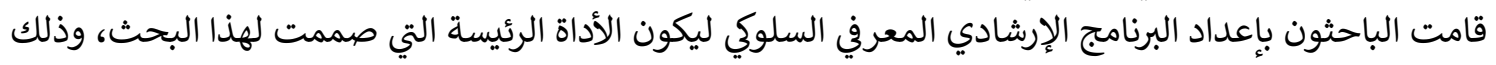

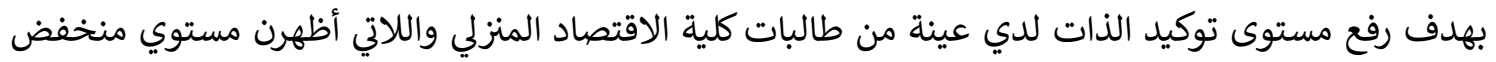

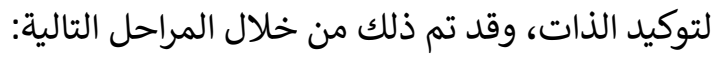

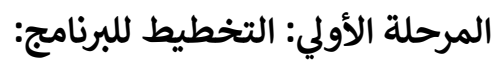

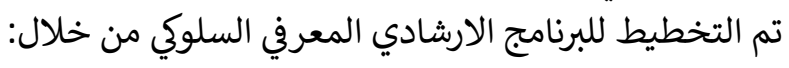

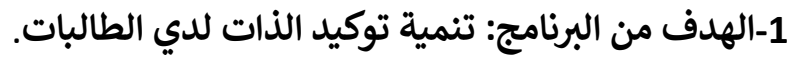

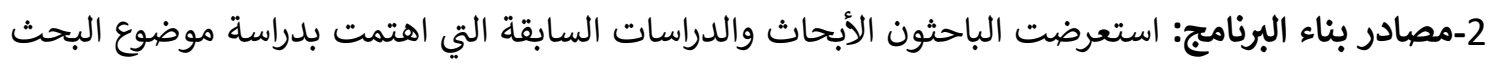

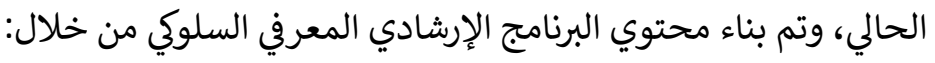

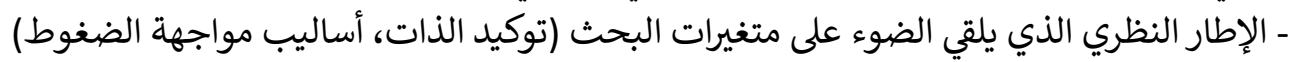

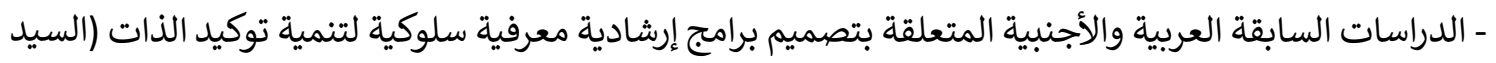

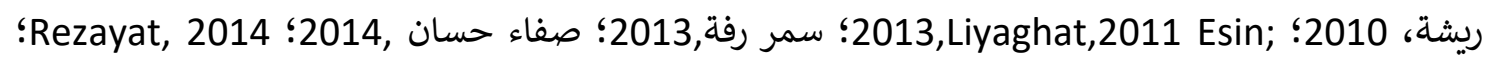
وردة, 2015 , Erickson\&Noonan وردة ,2018؛ نجلاء ياسين ,2018). ـ الدراسة الاستطلاعية الميدانية والتي تمت من خلال تطبين إسيق مقياس توكيد الذات للدكتور طريف فرج (1998)

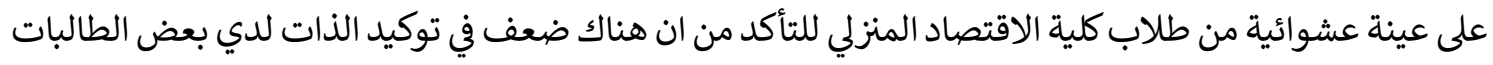
داخل الكلية.

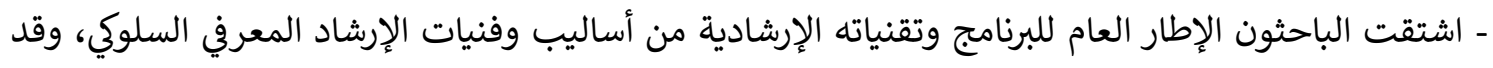

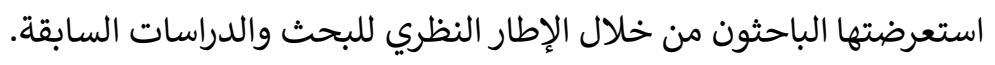

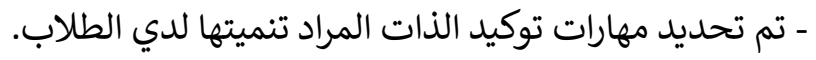

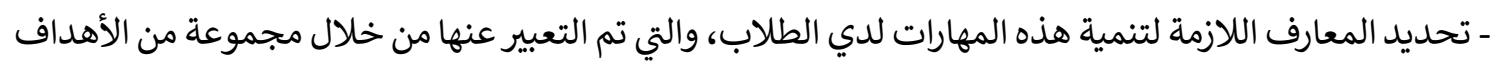

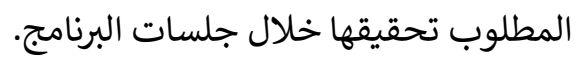

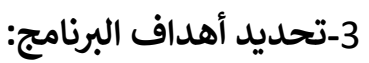
تم وضع أهداف البرنامج الارشادي المعرفي السلوكي، وروعي أن تكون الأهداف واقعية وقابلة للتحقيق ومناسبة

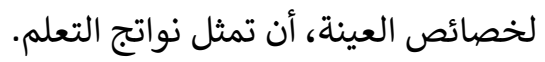

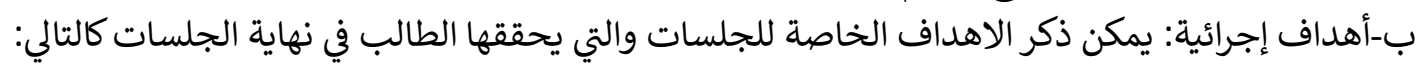
- يتعرف على معني توكيد الذات.

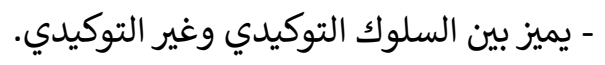

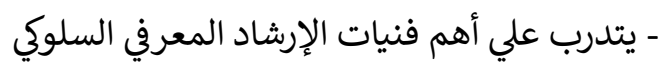
- يعدل المعتقدات السلبية غير المنطقية إلى معتقدات الإن المعرفي السكي منطقية.

JHE, 2021, 31(2): pp 267-308 . يتم طباعتها في جامعة المنوفية، جميع حقوق الطبع محفوظة للمجلة. 


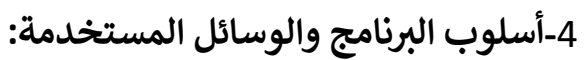

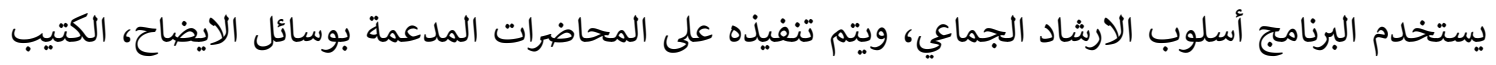

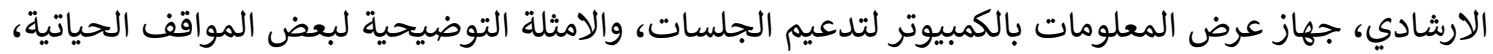

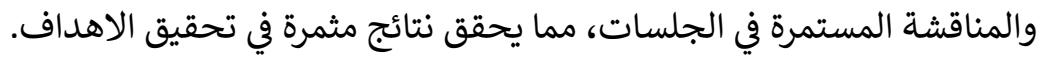
5-إعداد الخطة الزمنية لتنفيذ البرنامج: تم تحديد الزمن المناسب للجلسات من خلال محتوي الجلسات ويتراوح في الجلسات من (60-90) دقيقة للجلسة الواحدة.

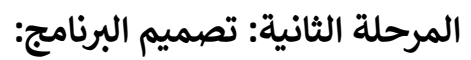

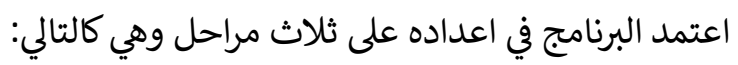

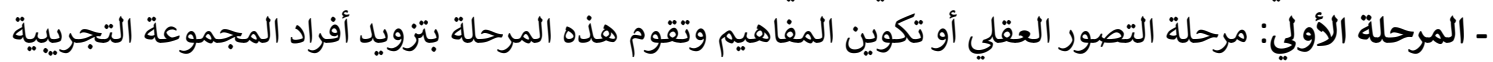

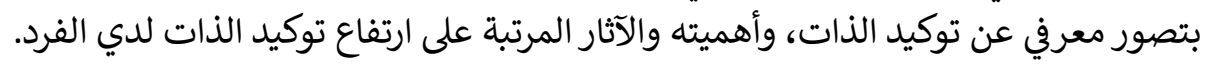

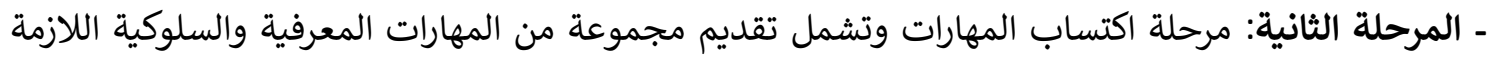

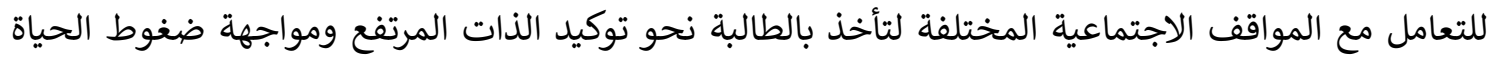
اليومية المختلفة. ـ المرحلة الثالثة: مرحلة التطبيق وتساعد هذه المرحلة أفراد المجموعة التجريبية على تطبيق ما تعلموه من مهارات توكيد الذات المختلفة في حياتهم اليومية.

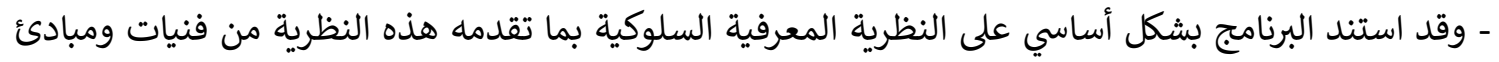

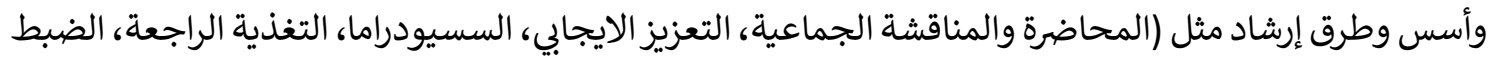

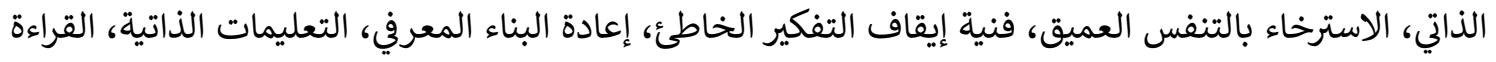

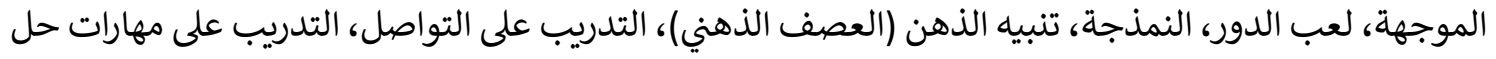

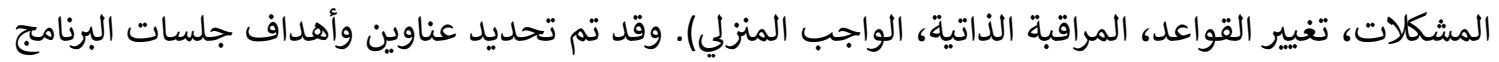

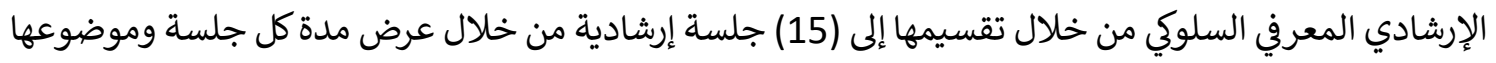

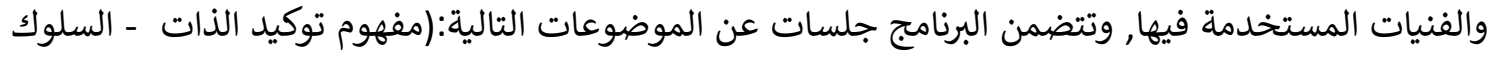

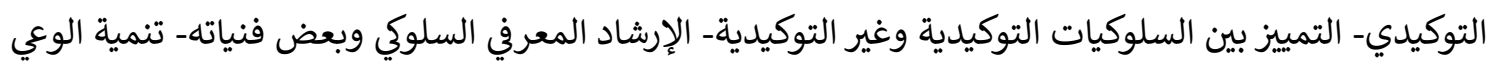

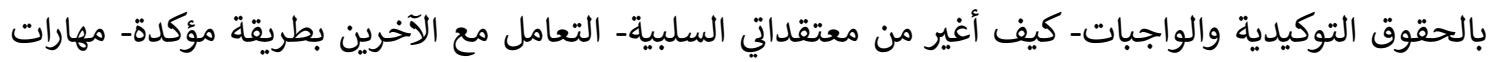

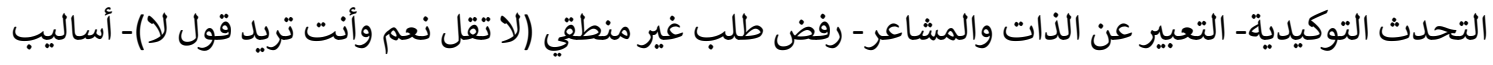

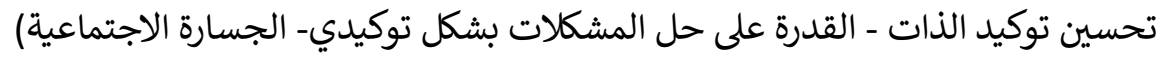

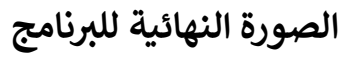

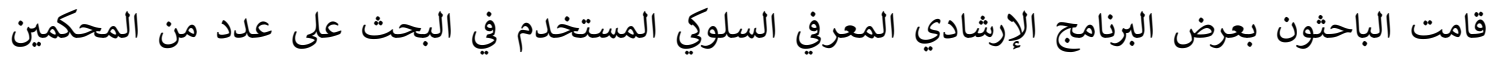

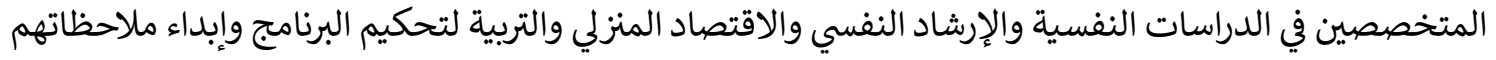

JHE, 2021, 31(2): pp 267-308 . يتم طباعتها في جامعة المنوفية، جميع حقوق الطبع محفوظة للمجلة. 
حول بناء البرنامج، وتم اجراء بعض التعديلات بناءً على رأي وملاحظات المحكمين، وفي ضوء مقترحاتهم وتوجيهاتهم أصبح البرنامج جاهزاً للتطبيق.

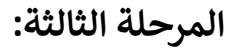

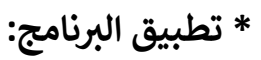
بعد الانتهاء من تصميم البرنامج، تم القيام بكل ما يتعلق بتطبيق البرنامج الإرشادي من إجراءات كما يلي:

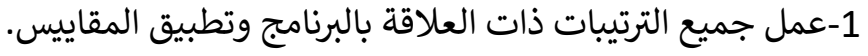

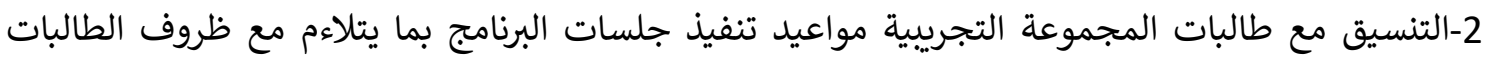
المشاركات بالحضور لجلسات البرنامج. 3-توفير مساعدات التطبيق من وسائل سمعية وبصرية.

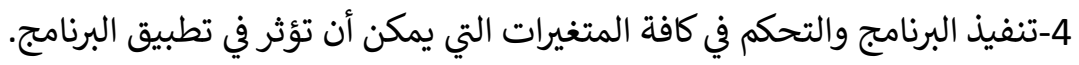

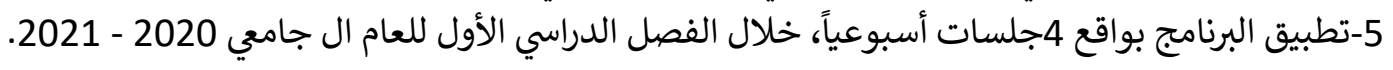
المرحلة الرابعة: تقييم البرنامج: 1-تقييم الجلسات:

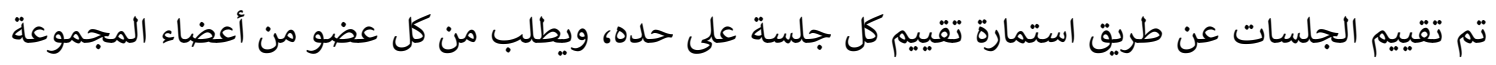

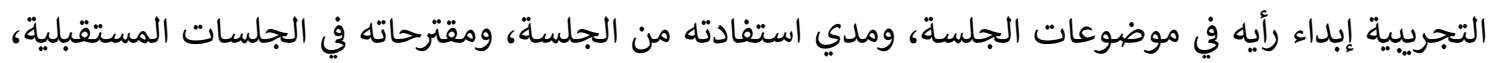

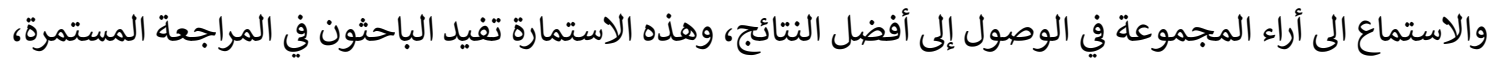

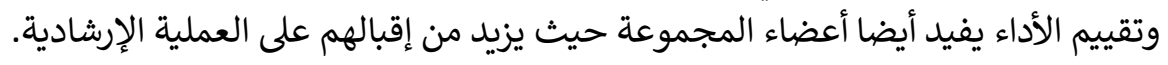

3-تطبيق الأدوات بعد الانتهاء من البرنامج مباشرة.

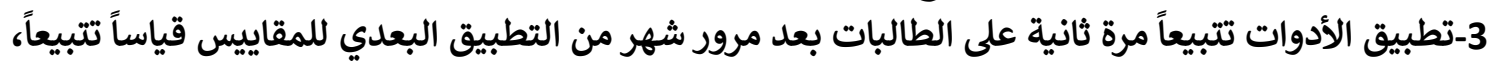
وذلك لمتابعة أثر البرنامج. نتائج البحث والتوصيات:

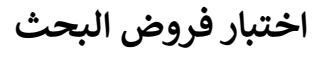

النتائج المتعلقة بالتحقق من صحة البحة الفرض الأول وتفسيرها

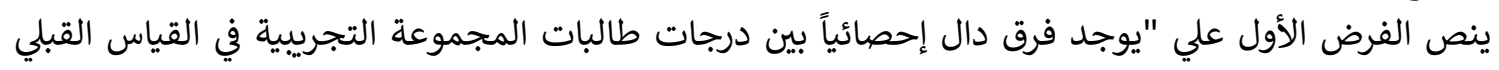

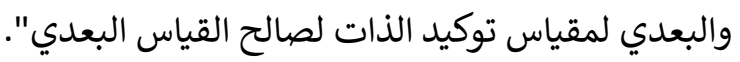
ولاختبار صحة هذا الفرض تم وصف وليعيل وتلخيص بيانات البحث بحساب (المتوسط الحسابي، الانحراف المعياري)

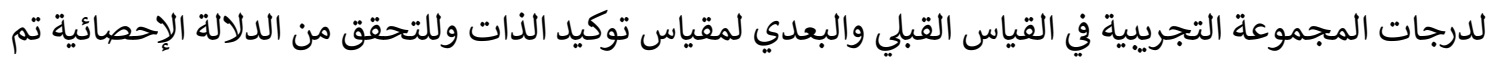

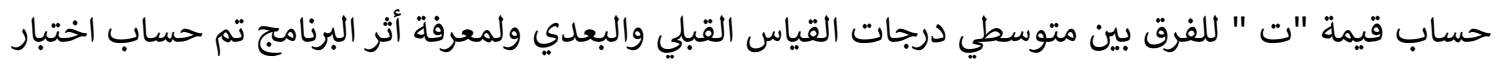

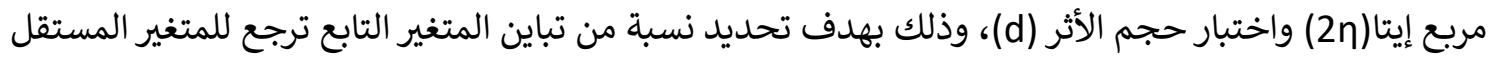
ويوضح ذلك الجدول التالي:

JHE, 2021, 31(2): pp 267-308 . يتم طباعتها في جامعة المنوفية، جميع حقوق الطبع محفوظة للمجلة. 
جدول (11): نتائج اختبار " ت " للفرق بين متوسطي درجات القياس القبلي والبعدي لمقياس توكيد الذات

\begin{tabular}{|c|c|c|c|c|c|c|c|c|c|}
\hline مستوي & الأثر & مريع ايتا & الاحصائ الدلاية & الحرية & قيمة & اللانحراف & الفرق بين & عنوان البعد & رقم \\
\hline وأثر كبير & 2.14 & 0.53 & مستوي & 29 & 5.765 & 5.07 & 5.33 & الوعي بالحقوق & 1 \\
\hline وأثر كبير & 2.42 & 0.59 & مستوي & 29 & 6.506 & 6.09 & 7.23 & التعبير عن الذات & 2 \\
\hline وأثر كبير & 3.58 & 0.76 & مستوي & 29 & 9.649 & 4.54 & 8.00 & التعبير عن المشاعر & 3 \\
\hline فأثر كبية & 4.09 & 0.81 & مستوي & 29 & 11 & 5.83 & 11.70 & الجسارة الاجتماعية & 4 \\
\hline وأثر كبير & 5.72 & 0.89 & مستوي & 29 & 15.39 & 5.10 & 14.33 & التواصل مع الآخرين & 5 \\
\hline فأثلية & 1.31 & 0.30 & مستوي & 29 & 3.535 & 4.91 & 3.17 & البناء المعرفي & 6 \\
\hline وأثر كبير & 6.52 & 0.91 & مستوي & 29 & $\begin{array}{c}17.54 \\
6\end{array}$ & 15.54 & 49.77 & توكيد الذات ككل & 7 \\
\hline
\end{tabular}

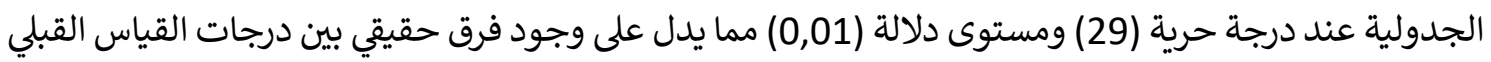

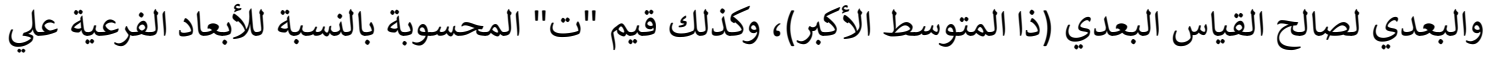

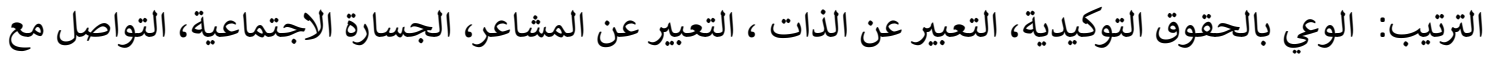

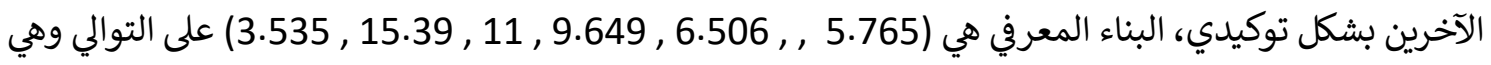

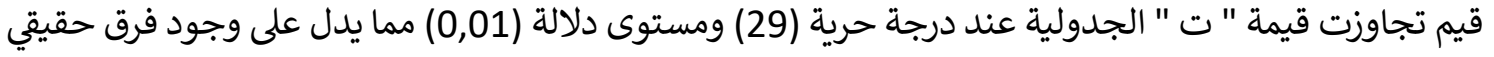

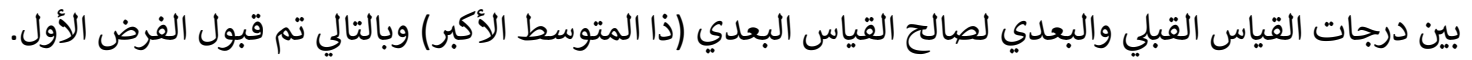

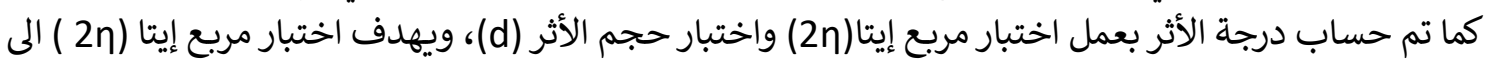

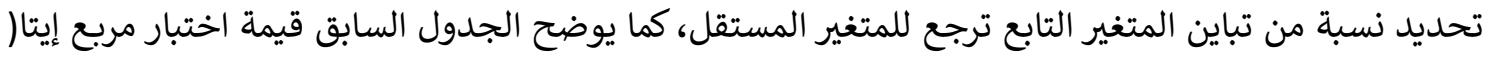

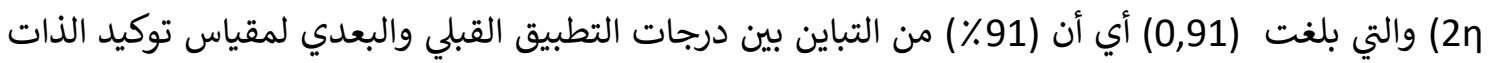

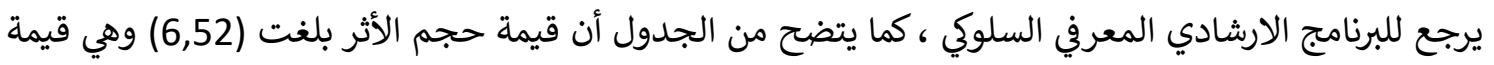

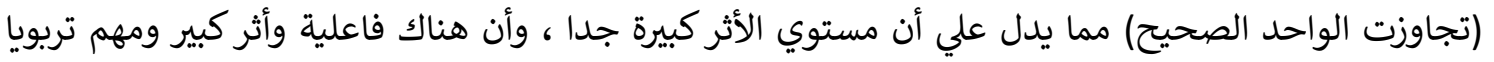
للبرنامج الإرشادي المعرفي السلوكي في تنمية توكيد الذات ككل وكذلك اله بالنسبة للأبعاد الفرعية علي حدة. 
وقد أرجعت الباحثون ذلك إلى البرنامج الإرشادي المعرفي السلوكي، وحرص أفراد المجموعة التجريبية على حضور

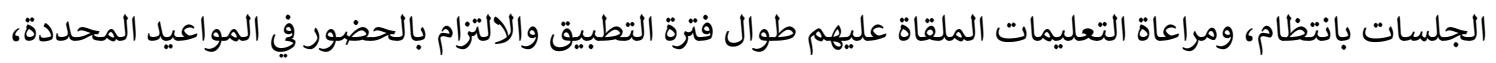

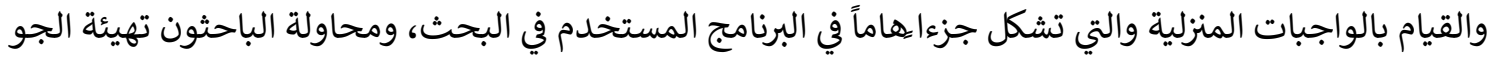

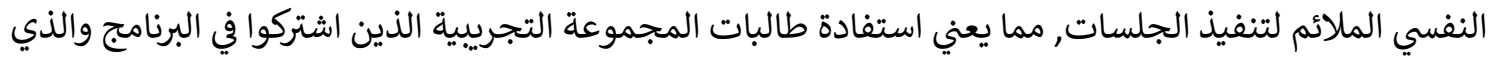

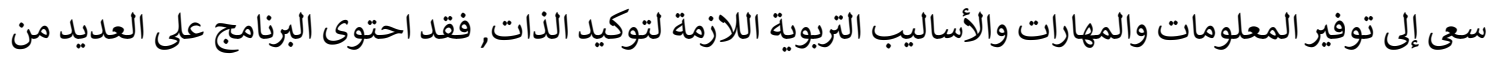

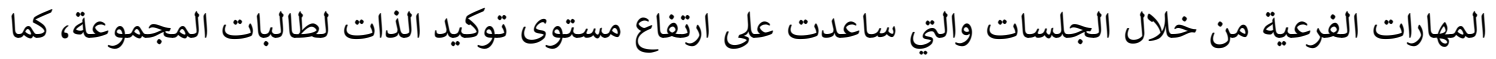

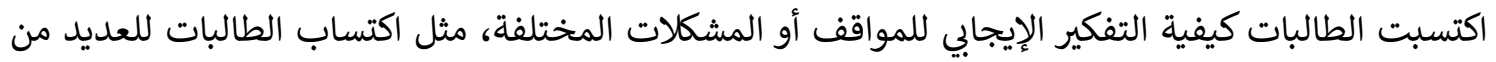

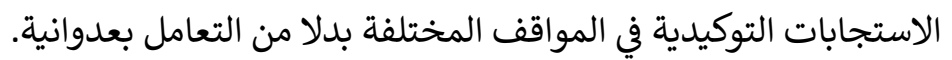

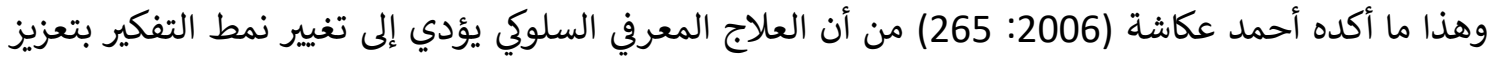

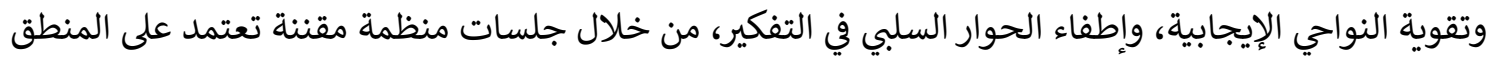

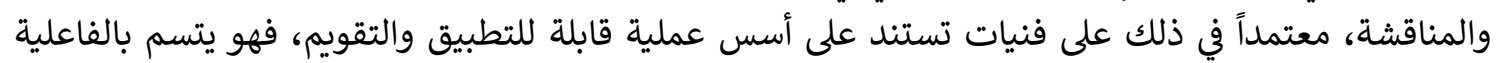
والتنظيم يتحدد بوقت معين.

ويتفق ذلك مع ما توصلت اليه بعض الدراسات من فاعلية البرامج الإرشادية المعرفية السلوكية في تنمية توكيد

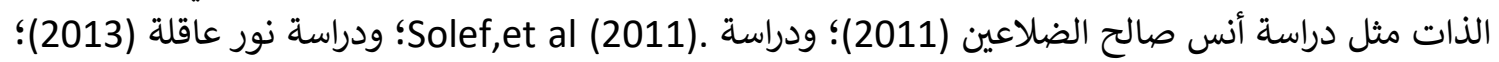

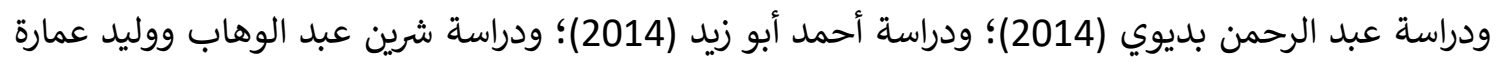

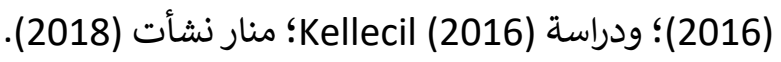

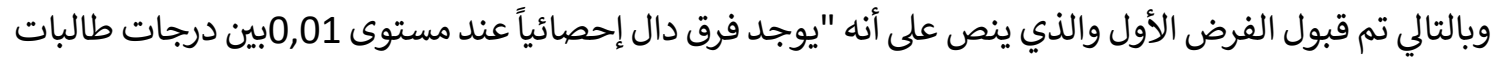

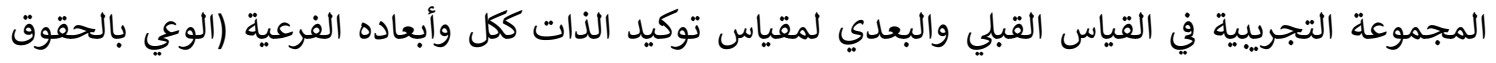

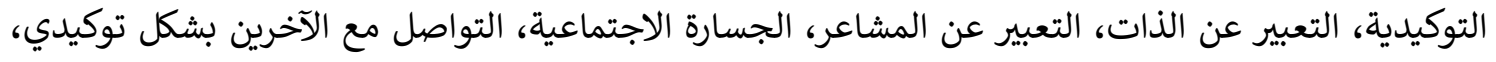

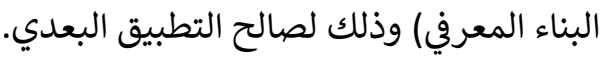

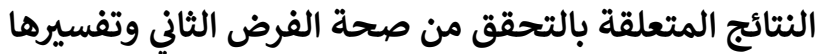

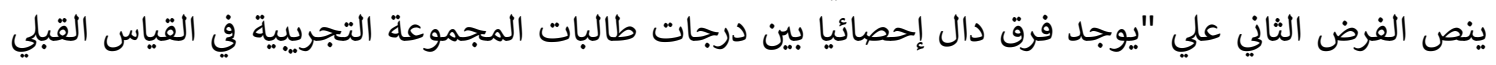

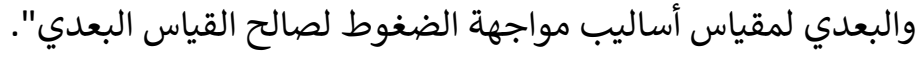
ولاختبار صحة هذا الفرض تم وصف وتلخيص بيانات البحث بحساب (المتوسط الحسابي، الانحراف المعياري)

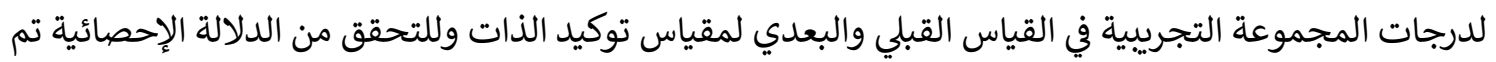

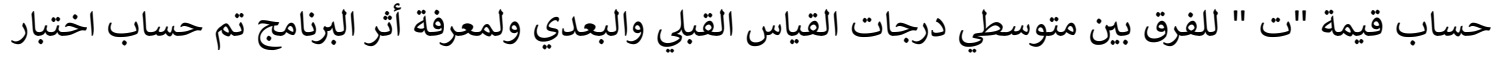

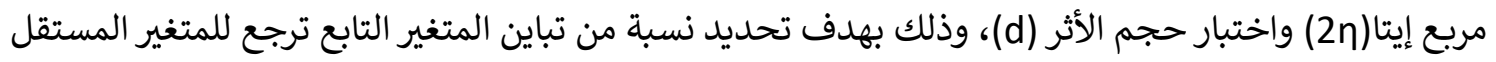
ويوضح ذلك الجدول التالي: 
جدول (12): نتائج اختبار " ت " للفرق بين درجات القياس القبلي والبعدي لمقياس أساليب مواجهة الضغوط

\begin{tabular}{|c|c|c|c|c|c|c|c|c|c|}
\hline مستوي & الأثر & مريع ايتا & الاحصائ الدلالة & الحرية & قيمة ت & اللفعياري المراف & الفرق بين & عنوان البعد & البعد \\
\hline وأثر كبير & 1.74 & 0.43 & مستوي & 29 & 4.68 & 6.17 & 5.27 & تحمل المسئولية & 1 \\
\hline وأثر كبير & 2.03 & 0.51 & مستوي & 29 & 5.48 & 6.83 & 6.83 & للمشكلة والتركيز عليها المنطقي & 2 \\
\hline وأثر كبير & 2.92 & 0.68 & مستوي & 29 & 7.86 & 4.88 & 7.00 & للمشكلة والتركيز عليها المنطقي & 3 \\
\hline فأثر كبير & 2.26 & 0.56 & مستوي & 29 & 6.08 & 6.39 & 7.10 & للمشكلة والتركيز عليها المنطقي & 4 \\
\hline & 2.71 & 0.65 & مستوي & 29 & 7.29 & 4.13 & 5.50 & إعادة التفسير الإيجابي & 5 \\
\hline فأثر كبير & 2.00 & 0.50 & مستوي & 29 & 5.37 & 5.33 & 5.23 & وتقبل الأمر الواقع للمشكة & 6 \\
\hline وأثر كبير & 2.72 & 0.65 & مستوي & 29 & 7.33 & 6.88 & 9.20 & الانسحاب السلوكي & 7 \\
\hline وأثر كبير & 3.38 & 0.74 & مستوي & 29 & 9.09 & 27.78 & 46.13 & مواجهة الضغوط ككل & أسال \\
\hline \multicolumn{10}{|c|}{ 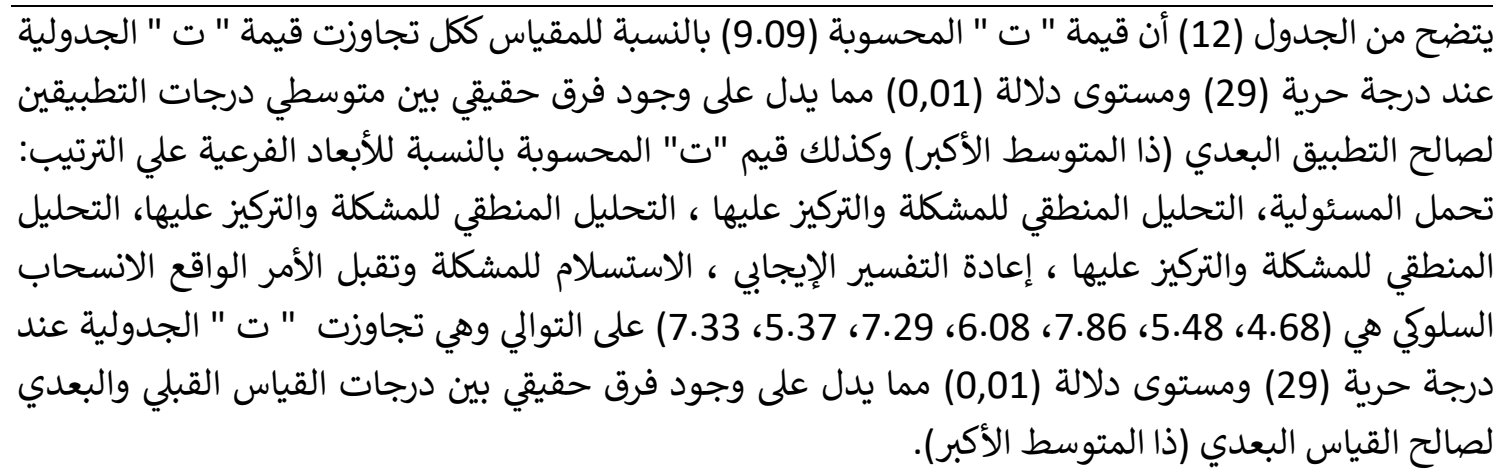 } \\
\hline \multicolumn{10}{|c|}{ 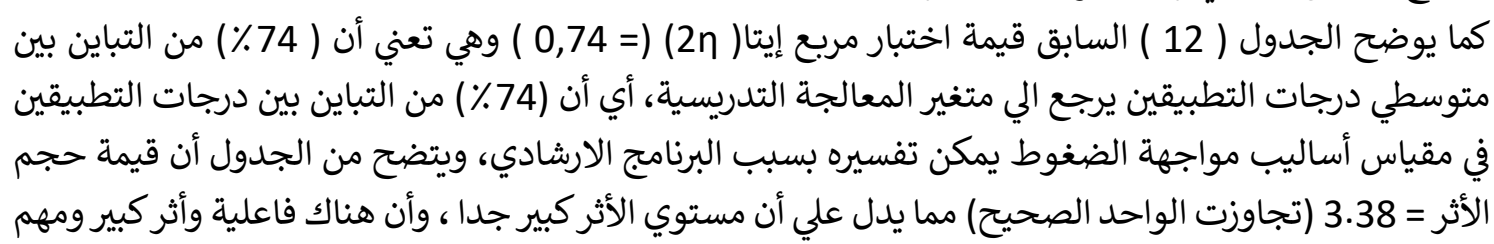 } \\
\hline
\end{tabular}

JHE, 2021, 31(2): pp 267-308 ـ يتم طباعتها في جامعة المنوفية، جميع حقوق الطبع محفوظة للمجلة. 
تربويا لبرنامج إرشادي معرفي سلوكي في تنمية أساليب مواجهة الضغوط ككل وكذلك بالنسبة للأبعاد الفرعية علي

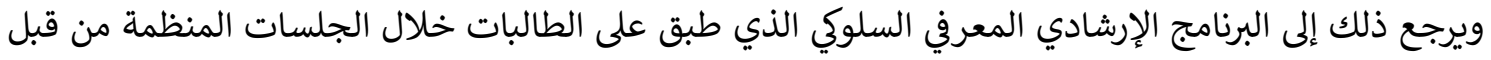

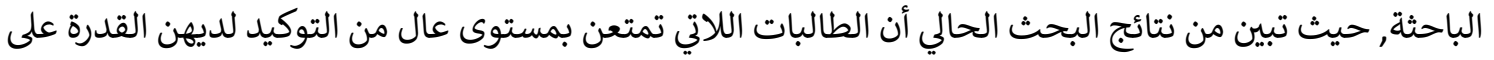

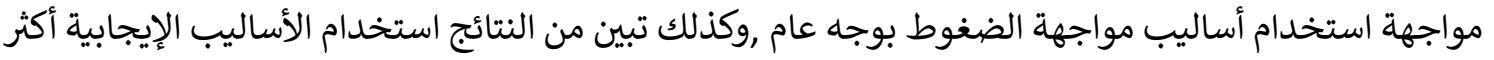

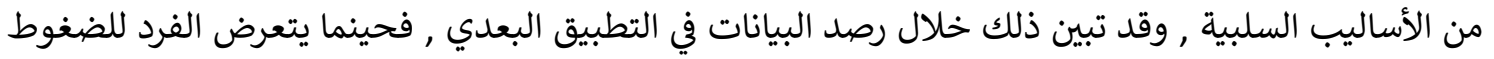

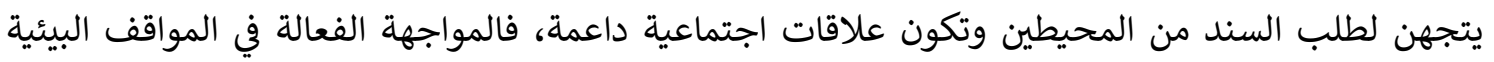

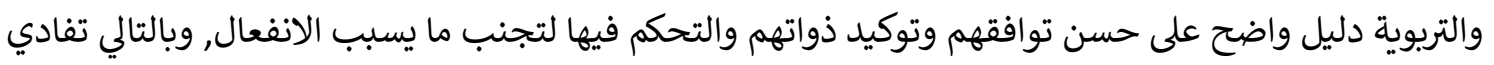

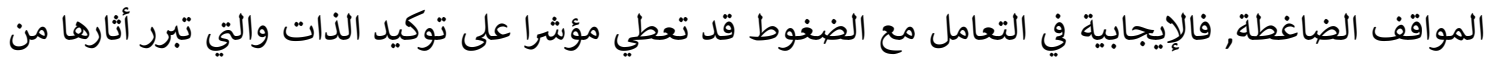

خلال مستوى الاستقرار النفسي والتعليمي.

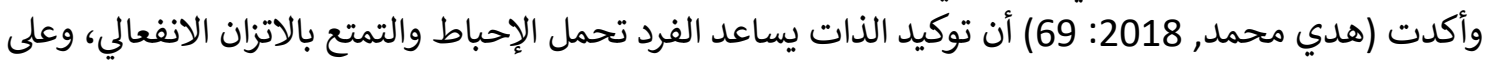

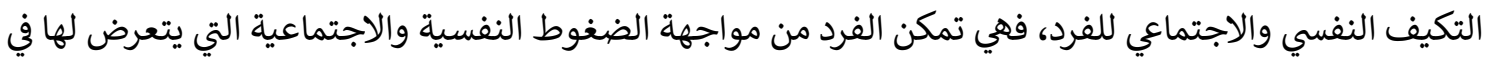
حياته. كما أن تنمية توكيد الذات من شأنه أن ينمي السلوكيات الإيجابية، وأكثر قدرة على مواجهة الضغوط. كما أنها أن اكتساب

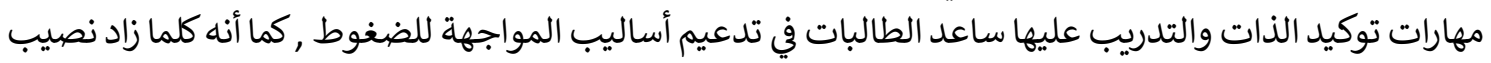

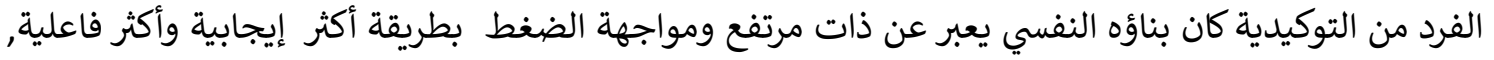

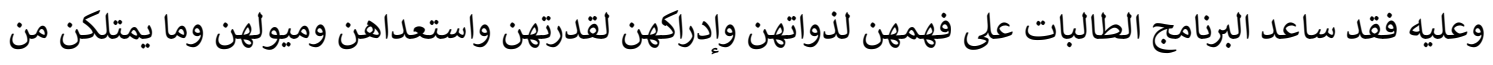

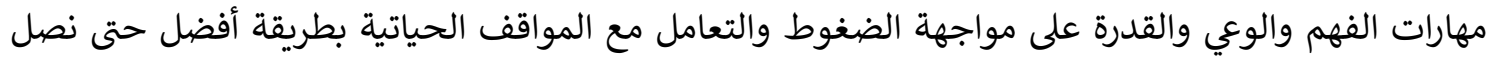
لمستوى عال من الصحة النفسية. كما ساعدت بعض فنيات الارشاد المعرفي السلوكي على اكتساب الطلاب بعض الصغ الأساليب الإيجابية في التعامل مع

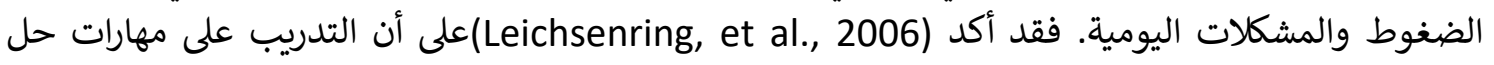

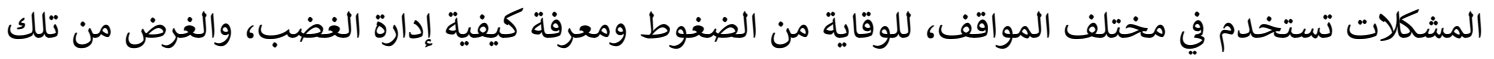

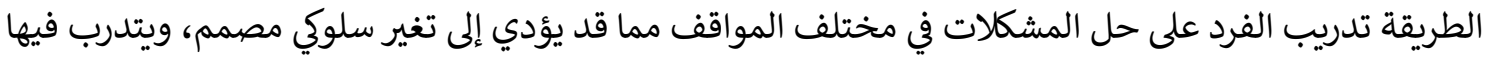

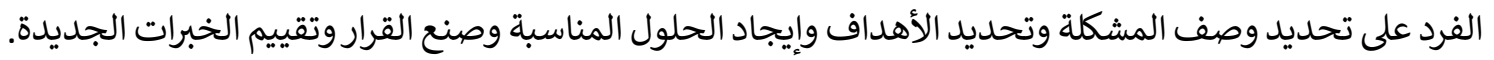

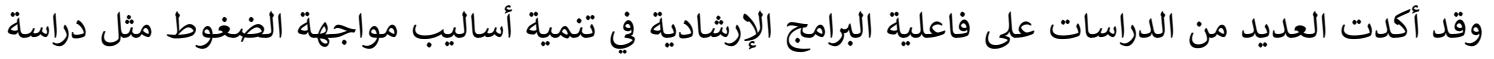

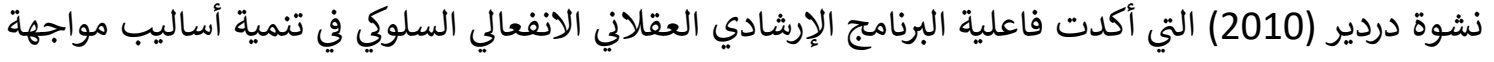

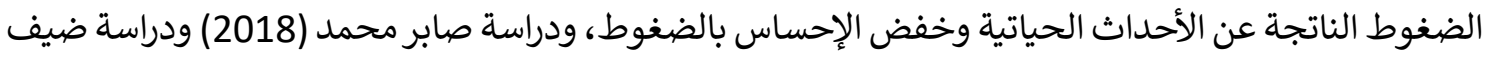

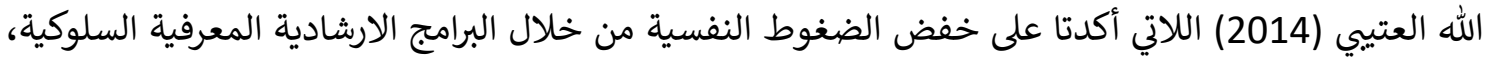

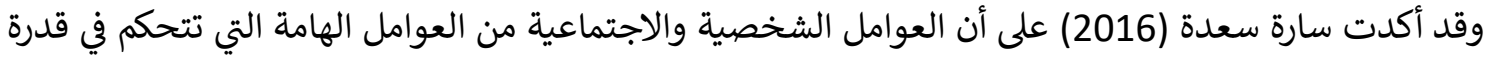

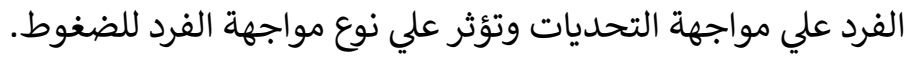


ويتفق ذلك مع ما توصلت اليه دراسة سليمان أحمد (2010: 34) وذلك من أن البرامج الإرشادية المعرفية

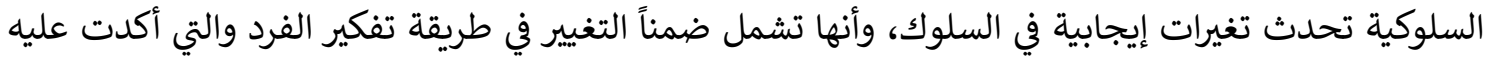
الباحثون طول فترة التطبيق.

وأكدت نتيجة هذا البحث من أثر البرامج الارشادية المعرفية السلوكية لتنمية توكيد الذات على أساليب مواجهة

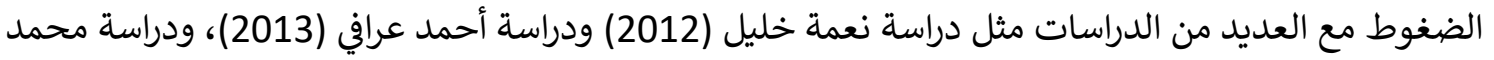

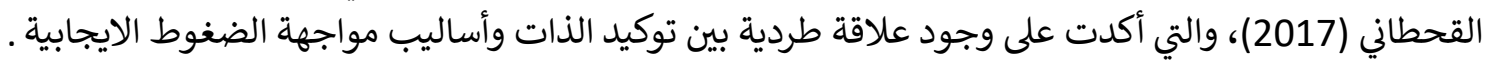

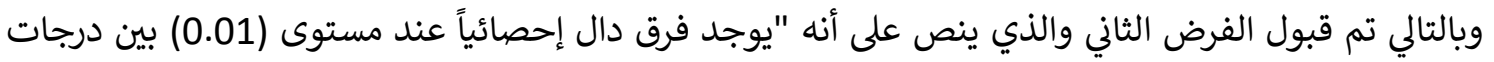

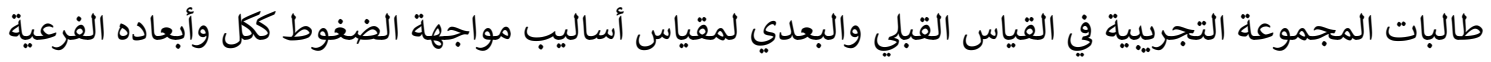

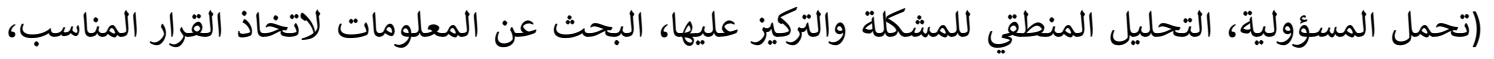

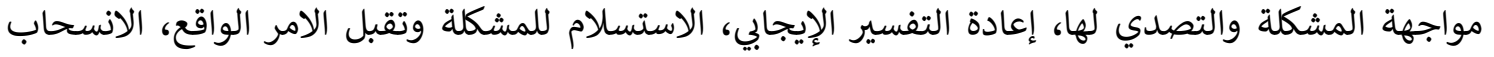

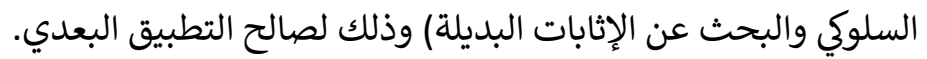

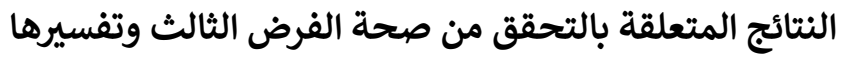

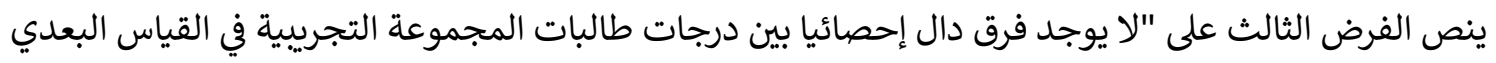
والتتبي لمقياس توكيد الذات".

ولاختبار صحة هذا الفرض قامت الباحثون بمقارنة متوسطي رتب دالتبات درجات طالبات المجموعة التجريبية في

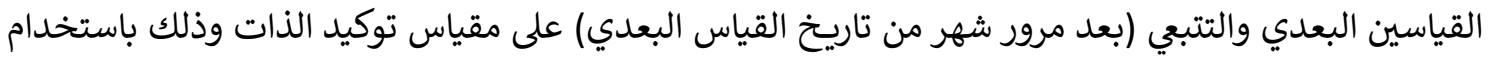

اخبار(ت)

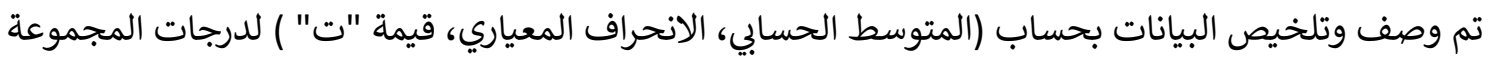

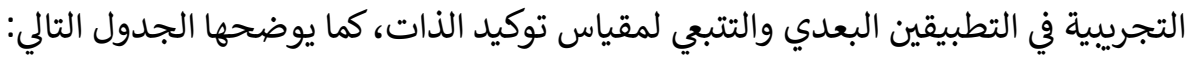
جدول (13): نتائج اختبار " ت " للفرق بين درجات القياس البعدي والتتبعي لمقيدي لمقياس توكيد الذات

\begin{tabular}{|c|c|c|c|c|c|c|}
\hline الاحصائية الدلالة & الحرية & قيمة ت & 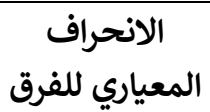 & متوسط الفرق & عنوان البعد & البعا \\
\hline غير دالة احصائيا & 29 & 1.795 & 0.61 & 0.20 & الوعي بالحقوق التوكيدية & 1 \\
\hline غير دالة احصائيا & 29 & 1.964 & 0.84 & 0.30 & التعبير عن الذات & 2 \\
\hline غير دالة احصائيا & 29 & 1.989 & 1.10 & 0.40 & التعبير عن المشاعر & 3 \\
\hline غير دالة احصائيا & 29 & 2 & 1.83 & 0.67 & الجسارة الاجتماعية & 4 \\
\hline غير دالة احصائيا & 29 & 1.976 & 2.03 & 0.73 & التواصل مع الآخرين بشكل توكيدي & 5 \\
\hline غير دالة احصائيا & 29 & 1.659 & 1.43 & 0.43 & البناء المعرفي & 6 \\
\hline غير دالة احصائيا & 29 & 2.003 & 5.10 & 1.87 & توكيد الذات ككل & \\
\hline
\end{tabular}

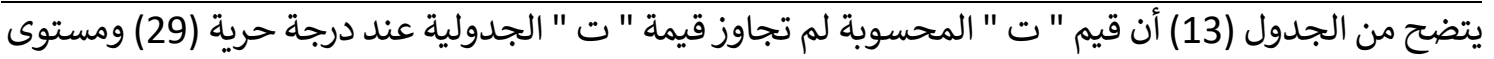

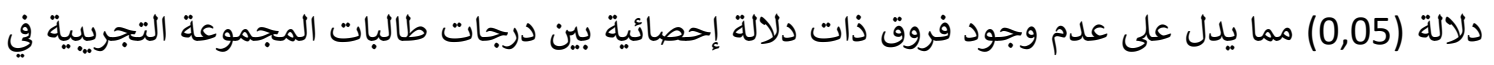
القياس البعدي والتتبعي لمقياس توكيد الذات ككل وابعاده الفردية. 
وبالتالي تم قبول الفرض الذي ينص على عدم وجود فرق دال إحصائياً بين درجات التطبيق البعدي والتتبعي

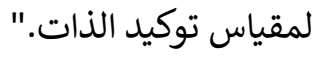
وذلك ما يعني استمرار فاعلية وأثر البرنامج الإرشادي المعرفي السلوكي في تنمية توكيد الذات ككل وكذلك بالنسبة للأبعاد الفرعية على حدة. وتشير هذه النتائج إلى استمرار أثر فاعلية البرنامج، واحداد الثداث تغييرات إيجابية مستمرة في أنماط السلوك بعد فترة

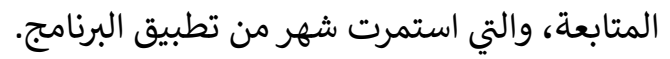

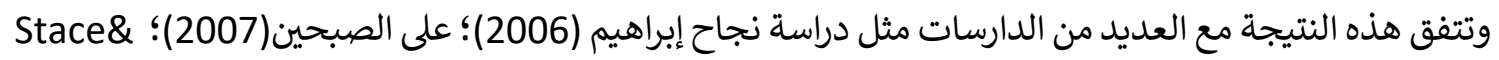

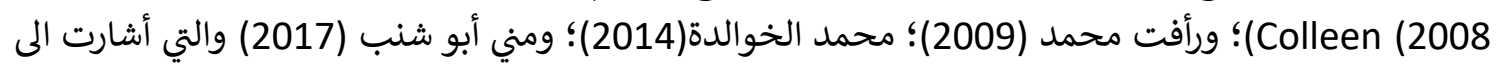

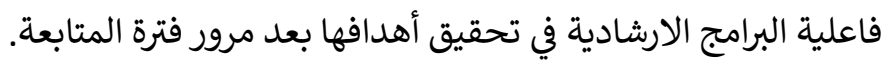

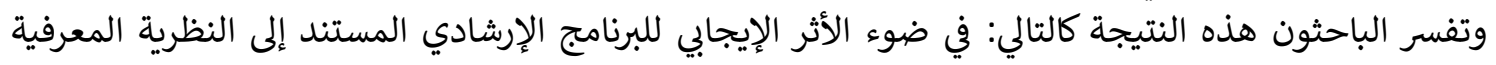

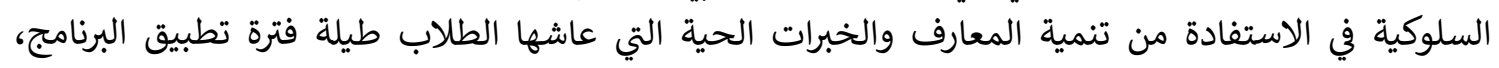

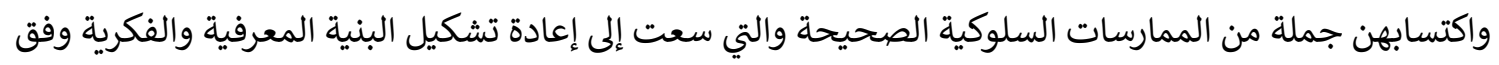

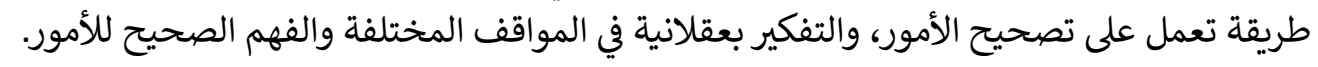

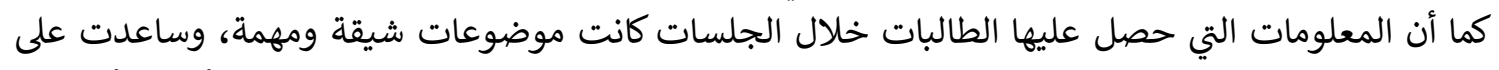

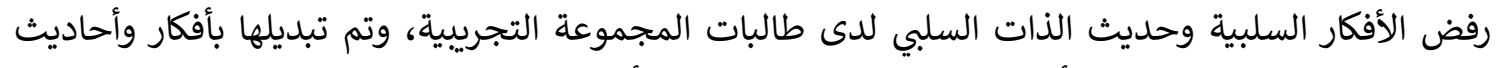

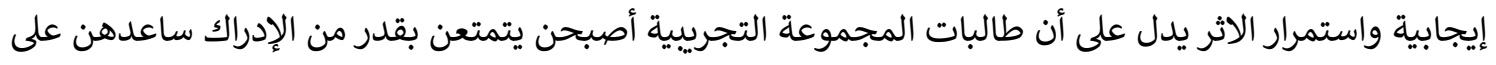

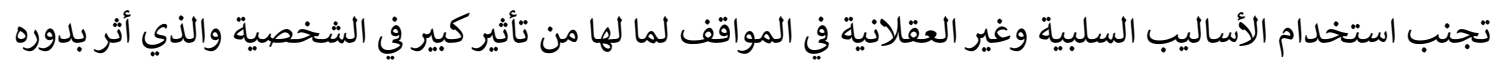
على تأكيد ذواتهن.

\section{النتائج المتعلقة بالتحقق دون من صحة الفرض الرابع وتفسيرها}

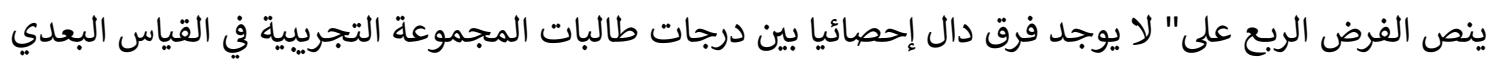

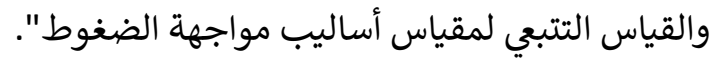
ولاختبار صحة هذا الفرض تم وصف وإياس التئي الخيص بيانات البحث بحساب (المتوسط الحسابي، الانحراف المعياري،

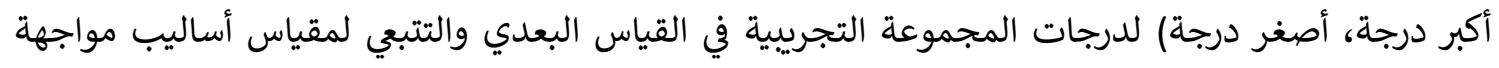

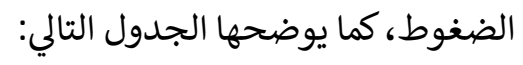
جدول (14): نتائج اختبار " ت " للفرق بيأ بين درجات القياس البعدي والتتبعي لمقياس أساليب مواجهة

\begin{tabular}{|c|c|c|c|c|c|c|}
\hline & & & & & وط & 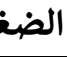 \\
\hline 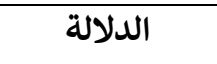 & درجة & قيمة & الانحراف & متوسط الفرق & & \\
\hline الاحصائية & 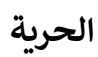 & ت & المعياري للفرق & 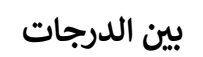 & عنوان البعد & بعد \\
\hline غير دالة احصائيا & 29 & 0.37 & 2.93 & 0.20 & تحمل المسئولية & 1 \\
\hline غير دالة احصائيا & 29 & 0.92 & 2.79 & 0.47 & التحليل المنطقي للمشكلة والتركيز عليها & 2 \\
\hline غير دالة احصائيا & 29 & 0.46 & 3.57 & 0.30 & البحث عن المعلومات لاتخاذ القرار المناسب & 3 \\
\hline
\end{tabular}

JHE, 2021, 31(2): pp 267-308 . يتم طباعتها في جامعة المنوفية، جميع حقوق الطبع محفوظة للمجلة. 


\begin{tabular}{|c|c|c|c|c|c|c|}
\hline 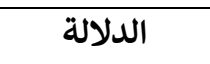 & درجة & قيمة & الانحراف & متوسط الفرق & \multirow{2}{*}{\multicolumn{2}{|c|}{ البعد عنوان البعد }} \\
\hline الاحصائية & 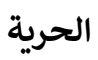 & ت & المعياري للفرق & بين الدرجات & & \\
\hline غير دالة احصائيا & 29 & 1.16 & 3.79 & 0.80 & مواجهة المشكلة والتصدي لها & 4 \\
\hline غير دالة احصائيا & 29 & 1.90 & 2.50 & 0.87 & إعادة التفسير الإيجابي & 5 \\
\hline غير دالة احصائيا & 29 & 1.10 & 1.99 & 0.40 & الاستسلام للمشكلة وتقبل الأمر الواقع & 6 \\
\hline غير دالة احصائيا & 29 & 0.95 & 2.70 & 0.47 & الانسحاب السلوكي & 7 \\
\hline غير دالة احصائيا & 29 & 0.83 & 10.34 & 1.57 & أساليب مواجهة الضغوط ككل & \\
\hline
\end{tabular}

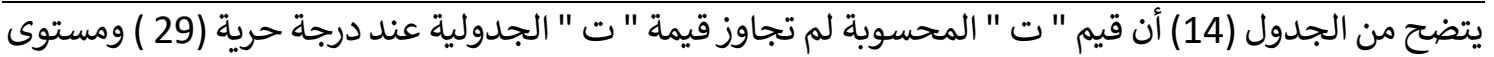

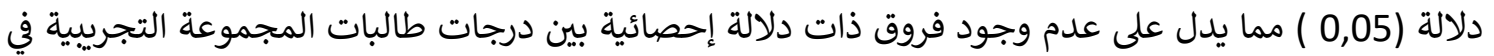

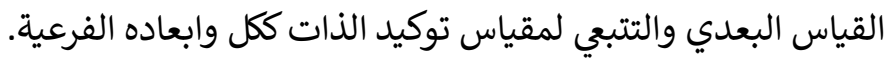
وبالتالي تم قبول الفرض الذي ينص على عدم وجود فرق دال إحصائياً بين درجات التطبيقين لمقياس أساليب

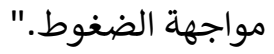
مما يعني استمرار فاعلية وأثر البرنامج الإرشادي المعرفي السلوكي في تنمية أساليب مواجهة الضغوط ككل وكذلك بالنسبة للأبعاد الفرعية على حدة. وتشير هذه النتائج إلى استمرار أثر فاعلية البرنامج، واحداثله النهاثه تغييرات إيجابية مستمرة في أنماط السلوك بعد فترة

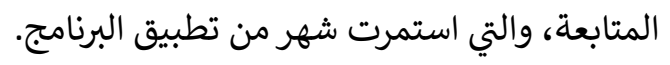

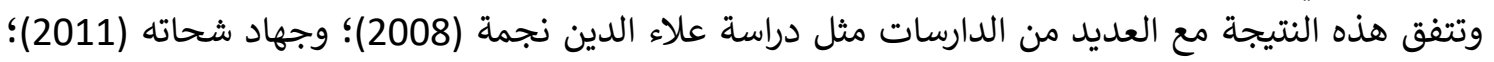

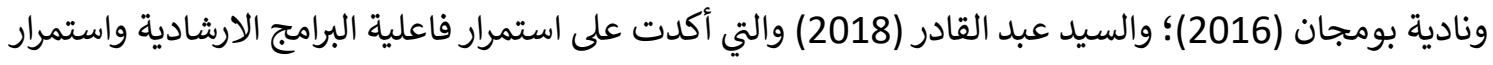
أثرها بعد التطبيق وترجع الباحثون هذه النتيجة إلى أن البرنامج المستخدم كان فعالايفي تنمية المهارات والخبرات الأساسية للتفاعل

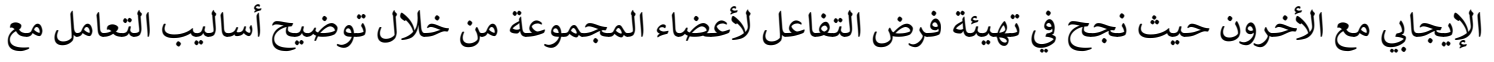

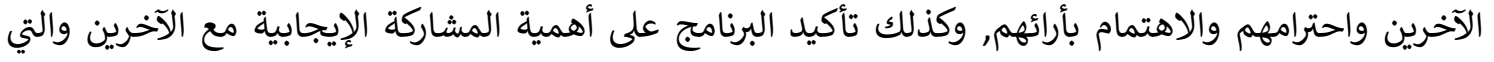

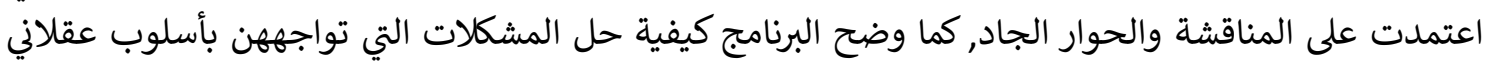

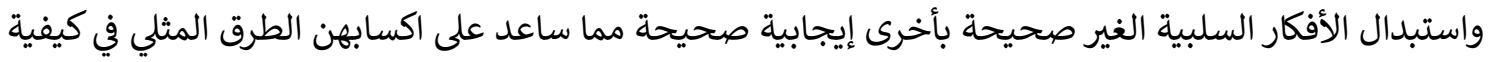

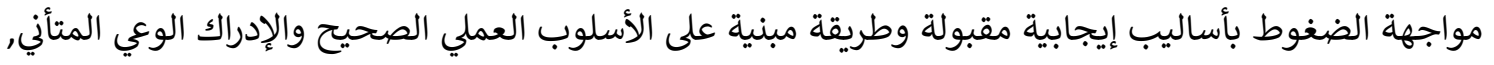

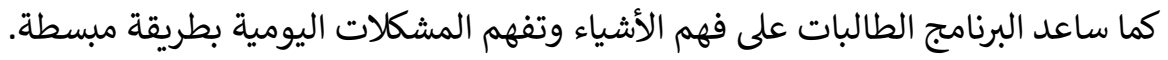

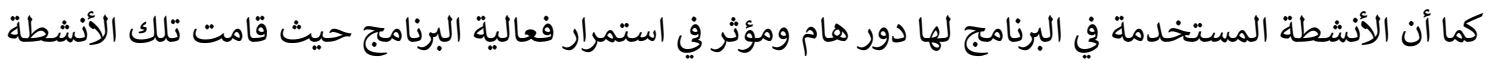

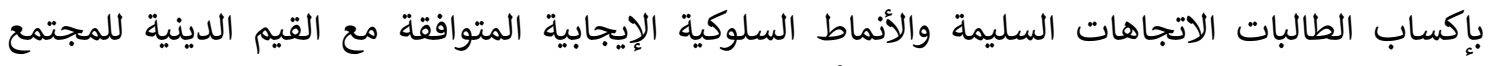

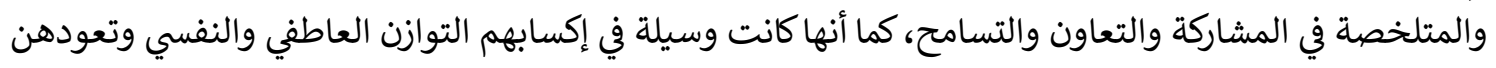
على الحياة في الأوساط الاجتماعية المختلفة. 
ويتضح من النتائج السابقة التي توصل اليها البحث الحالي أن البرنامج المقترح كان له تأثير فعال في تنمية توكيد

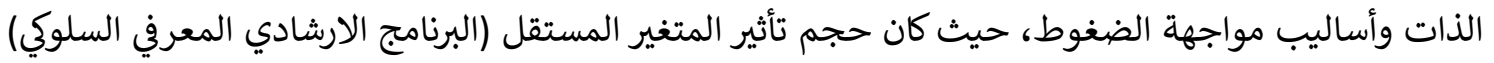

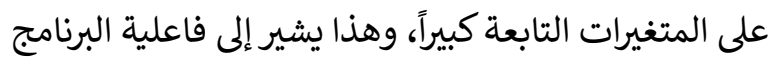
توصيات البحث:

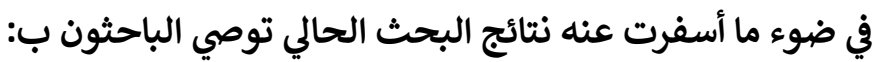

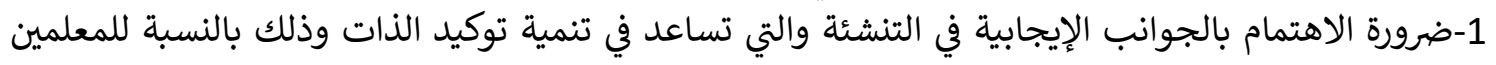
والمرشدين وأولياء الأمور. 2-عقد برامج ارشادية لتنمية توكيد الذات لدي الفئات الخاصة مثل الخجولين ومن يخشون مواجهة الآخرين، المكتئبين، الأطفال. 3-ضرورة الاهتمام بتقديم البرامج الإرشادية في المراحل التعليمية المختلفة لما لها من أهمية كبيرة في إكساب

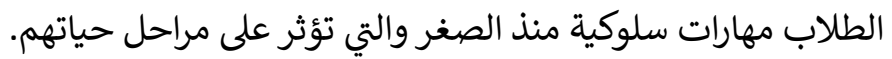

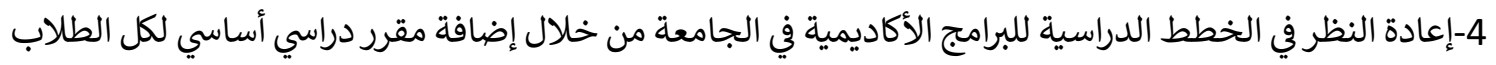

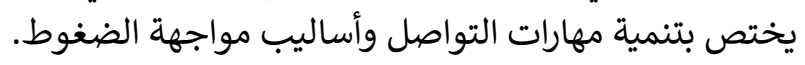
5-تطوير أداء القائمين على الأنشطة الطلابية وتدريبهم على طرات التوائ الإرشاد المعرفي السلوكي لما له من أهمية في

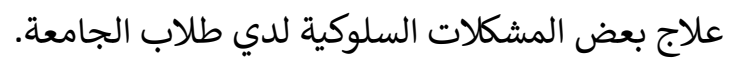

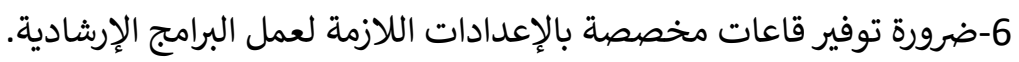

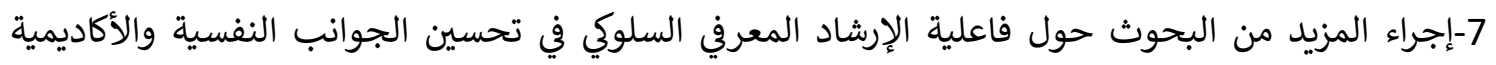
والاجتماعية لدي طلاب الجامعة. بحوث مقترحة: في ضوء ما ظهر من تساؤلات لم يتطرق اليها البحث الحالي يمكن اقتراح البحوث التالية التوالية:

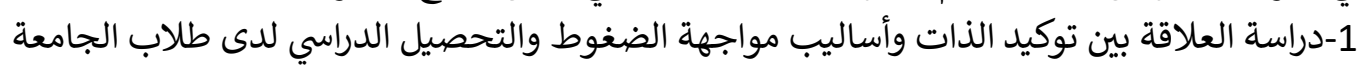

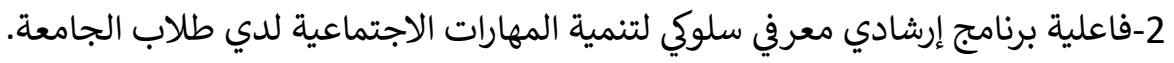

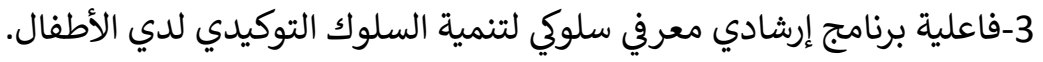

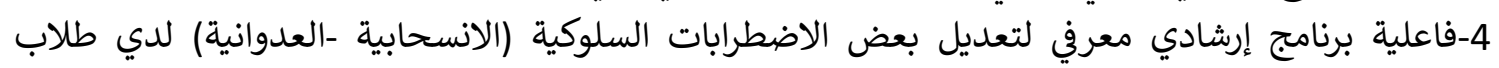
الجامعة. 5-دراسة أثر تنمية توكيد الذات وأساليب مواجهة الضغوط على ارتفاع مستوي التحصيل الدراسي لدي الطلاب.

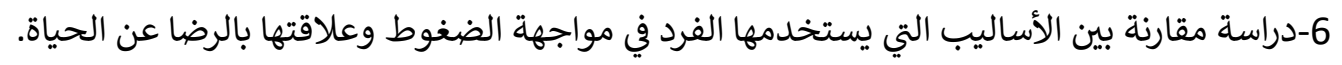

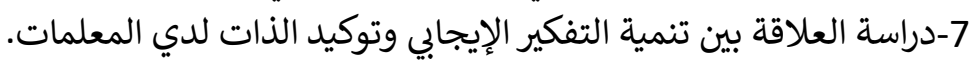

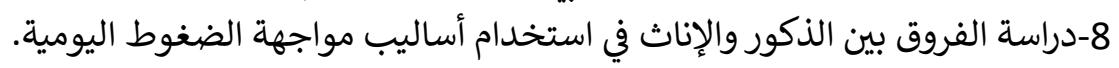

تضارب المصالح 
يعلن المؤلفون أنه ليس لديهم تضارب في المصالح فيما يتعلق بنشر هذه المقالة. هذا المقال مستخرج من رسالة

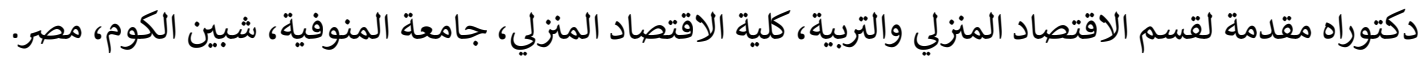

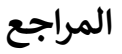

أولا المراجع العربية: واجع

أحمد أبو زيد (2014). فعالية برنامج علاجي سلوكي في تنمية مهارات تأكيد الذات لدي المراهقين المتخلفين عقليا

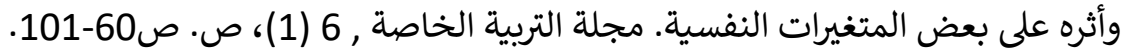

أحلام حسين وردة (2018). إعداد مقياس لقياس السلوك التوكيدي لدي طلبة جامعة بغداد. مجلة كلية التربية -

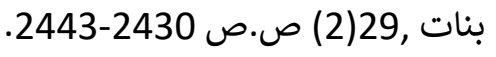

أسماء زهاني (2014). الصلابة النفسية وعلاقتها بأساليب مواجهة الضغوط النفسية لدي معلمات المتوسط.

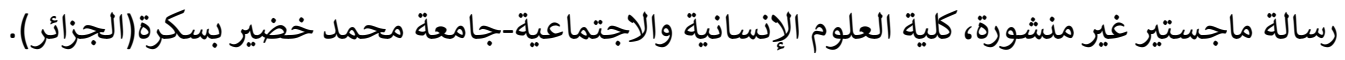
أسماء فتحي أحمد وميرفت عزي زكي (2012). التفكير الايجابي والسلوك التوكيدي كمنبئات بأبعاد التدفق النفسي

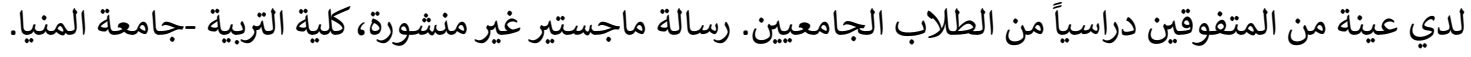
أشرف أحمد القانوع (2011). الكفاءة الاجتماعية وعلاقتها بأساليب مواجهة الضغوط عند المصابين بالاضطرابات

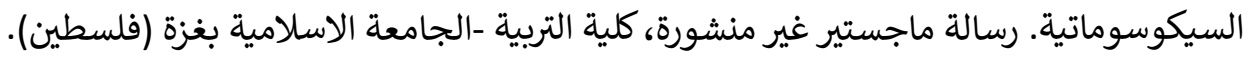
السيد العبادية عبد القادر (2018). فاعلية برنامج ارشادي نفسي في التخفيف من العنف المدرسي. رسالة دكتوراه غير منشورة ,كلية العلوم الاجتماعية -جامعة وهران( الجزائر).

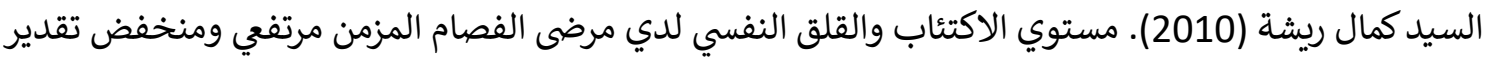

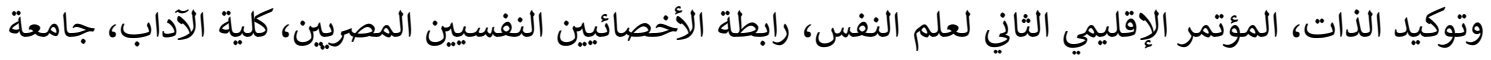
أسيوط , 281-310. أمل عبد الله الحارثي (2013). فاعلية برنامج إرشادي لتنمية توكيد الذات وضبط النفس لدي الطالبات الموهوبات

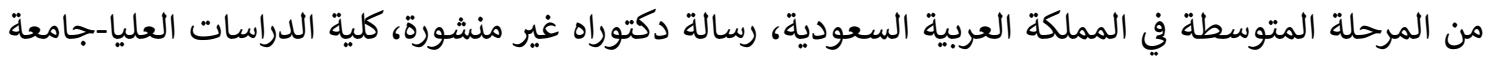
الخليج العربي. أمل محمد فوزي ومحمود سليمان عزب (2014). فاعلية العلاج المعرفي السلوكي في التخفيف من اضطراب المسلك لدي المراهقين. رسالة دكتوراه غير منشورة، كلية التربية-جامعة بنها.

أمل محمود سكر (2008). فاعلية برنامج معرفي سلوكي في تخفيف الضغط النفسي لدي عينة من مدرسي التربية

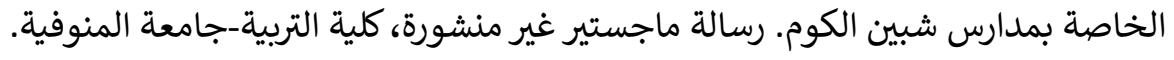


أنس صالح الضلاعين (2011). فاعلية برنامج توجيه جمعي لتحسين مهاراتي توكيد الذات وحل النزاعات لدي طلبة

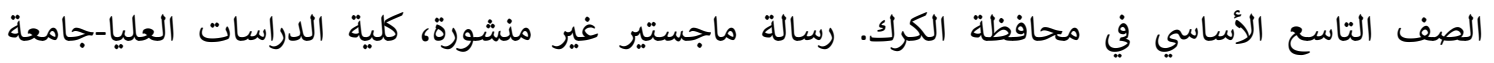
مؤتة(الأردن).

أنور راجح المنعمي (2013). فاعلية برنامج ارشادي معرفي سلوكي في تنمية الأمن النفسي لدي المراهقين ذوي

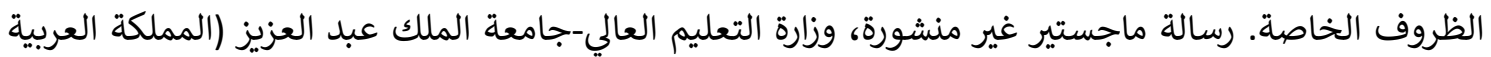

السعودية).

أية هشام عبد اللطيف (2018). التوكيدية لدي الطلبة ذوي الاعاقة البصرية وعلاقتها بالقدرة على تجهيز المعلومات. رسالة ماجستير غير منشورة، كلية التربية -الجامعة الاسلامية (غزة).

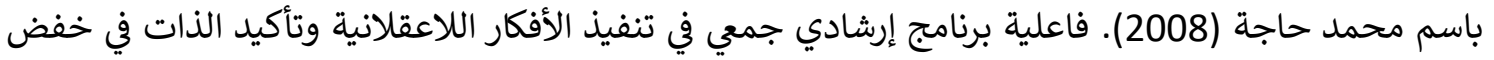

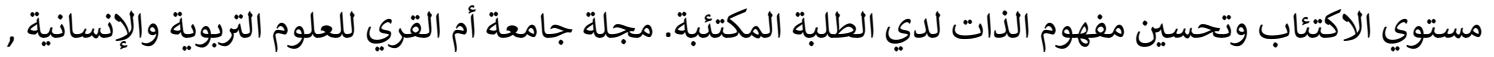

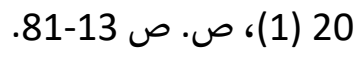

بيرني كروين وبيتر رودل وستيفن بالمر (2008). العلاج المعرفي السلوكي المختصر. (ترجمة: محمود عيد مصطفي). القاهرة: دار إيتراك للطباعة والنشر والتوزيع. جيهان صلاح الدين صقر (2008). فاعلية المهارات الاجتماعية التوكيدية والأنشطة السارة في علاج الاكتئاب

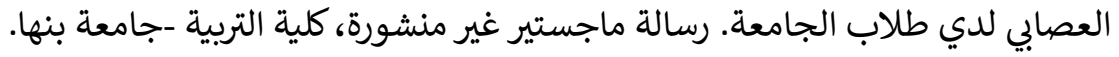
حامد ضيف الله الغامدي (2010). مدي فاعلية العلاج المعرفي السلوكي في خفض اضطراب القلق العام لدي الديا

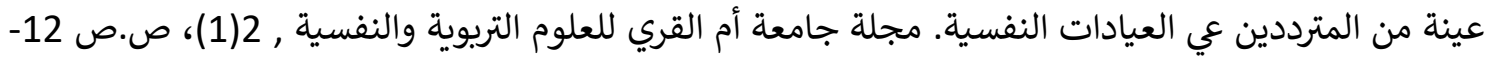

حسام الدين عزب محمود (2012). برنامج إرشادي معرفي سلوكي لتنمية توكيد الذات لدي عينة من الشباب

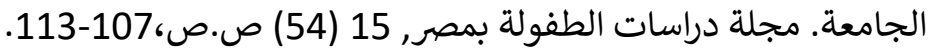

خالد محمد العبدلي (2012). الصلابة النفسية وعلاقتها بأساليب مواجهة الضغوط النفسية لدي عينة من طلاب المرحلة الثانوية المتفوقين دراسيا والعاديين بمدينة مكة المكرمة. رسالة ماجستير غير منشورة، كلية التربية-جامعة أم القري (المملكة العربية السعودية). خلود خالد ناصر (2012). الفروق في السلوك التوكيدي بين طالبات التعليم المتوسط والثانوي والجامعي بجدة. رسالة ماجستير غير منشورة، كلية التربية-جامعة أم القري (المملكة العربية السعودية). دينا حسين الظاهر (2008). فاعلية برنامج ارشادي في تنمية المهارات الاجتماعية وتقدير الذات لدي المعاقات

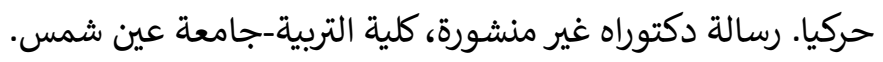


رحاب محمد عبد الرحيم (2013). فعالية برنامج إرشادي معرفي سلوكي لخفض اضطراب الشره العجمي لدي عينة

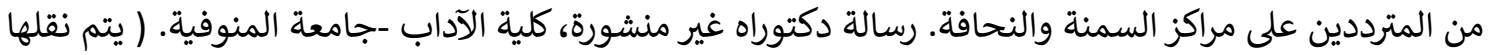

قبل رقية عبد الله )

رشاد علي موسي ومديحة منصور الدسوقي (2011). علم النفس بين المفهوم والقياس. القاهرة: عالم الكتب. (يتم وضعه بعد رحاب).

رقية عبد الله الصرايرة (2015). فاعلية برنامج إرشادي لتحسين مهارة توكيد الذات لدي طالبات المرحلة

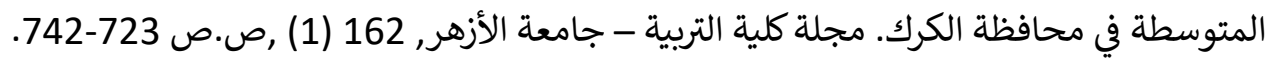
رمضان سعيد الحلو (2012). فاعلية تطبيق برنامج إرشادي في فنيات العقل والجسم لزيادة توكيد الذات لدي

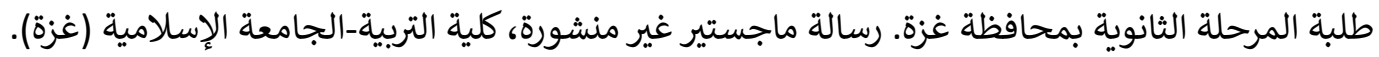
روبين داينز (2006). إدارة القلق. (ترجمة: دار الفاروق). القاهرة: دار الفاروق. زينب عبد الرحيم أبو الغيط (2016). أساليب مواجهة الضغوط وعلاقتها بالسعادة النفسية وفعالية الذات لدي طلبة كلية الاقتصاد المنزلي-جامعة المنوفية. رسالة ماجستير غير منشورة، كلية الاقتصاد المنزلي - جامعة

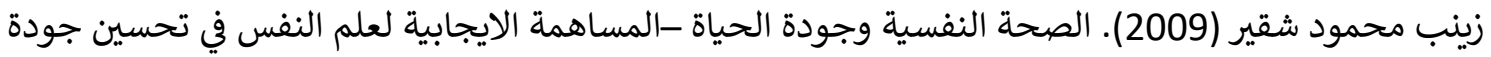

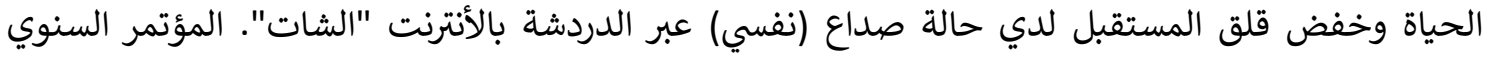

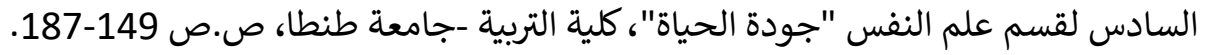

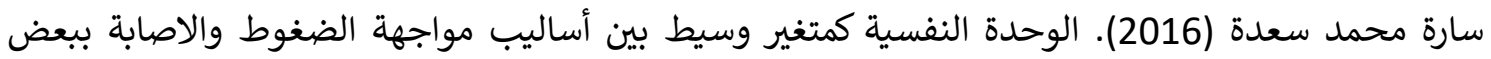
الاضطرابات السيكوسوماتية. رسالة ماجستير غير منشورة، كلية الآداب-جامعة المنيط المنوفية. سعيدة لونيس (2012). مدي فاعلية برنامج التدريب التوكيدي في تنمية مستوي توكيد الذات لدي عينة من

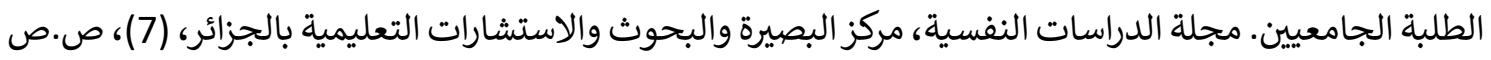

سليمان رجب سيد احمد (2010). فاعلية العلاج المعرفي السلوكي في تخفيف أعراض العصاب القهري ذوي صعوبات التعلم. رسالة دكتوراه غير منشورة، كلية التربية -جامعة بنها. سمر سعود رفه (2013). مهارة توكيد الذات وعلاقتها بأساليب التنشئة الوالدية لدي عينة من طالبات جامعة أم

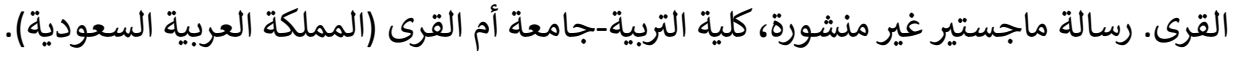


شرين عبد الوهاب أحمد ووليد محمد عمارة (2016). فعالية برنامج إرشادي عقلاني انفعالي لتحسين تأكيد الذات

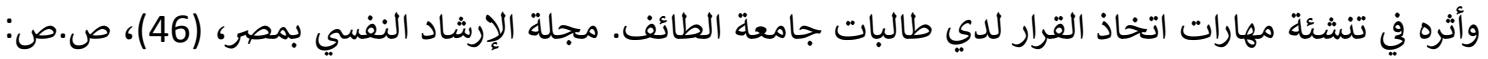

.128-53

شيلي تايلور (2008). علم النفس الصحي. (ترجمة: وسام بريك، فوزي داوود)، عمان (الاردن): دار الحامد للنشر والتوزيـع.

صابر فاروق محمد (2018). فاعلية برنامج ارشادي معرفي سلوكي في خفض الضغوط النفسية لدي امهات الاطفال

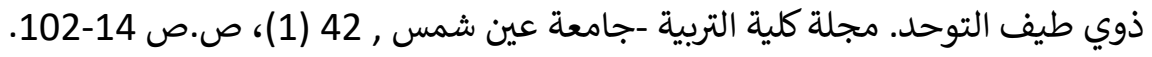

ضيف الله حمدان العتيبي (2014). فاعلية برنامج إرشادي معرفي سلوكي لتخفيف الضغوط النفسية لدي نزلاء

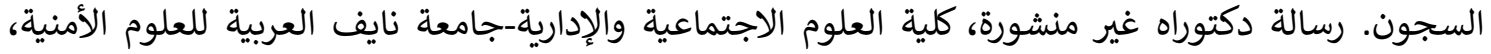
الرياض، (المملكة العربية السعودية). طه عبد العظيم حسين وسلامة عبد العظيم حسين (2006). استراتيجيات ادارة الضغوط التربوية والنفسية. عمان: دار الفكر. عبد الحفيظ جدو (2014). استراتيجيات مواجهة الضغوط النفسية لدي المراهقين ذوي صعوبات التعلم. رسالة

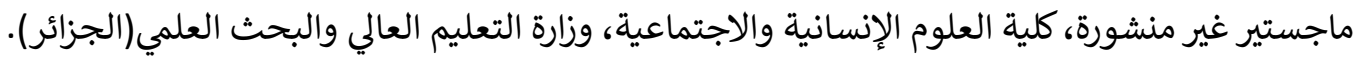
عبد الرحمن علي بديوي (2014): فاعلية برنامج إرشادي لتنمية مهارات التوكيدية وأثرة على مهارات الوعي بالمعرفة لدي الطلاب ذوي صعوبات تعلم الرياضيات بالجامعة. مجلة التربية الخاصة والتأهيل، 1 (4) , 128-

عبد الرحمن عيد الجهني (2011). المهارات الاجتماعية وعلاقتها بالسلوك التوكيدي والصلابة النفسية لدي طلبة

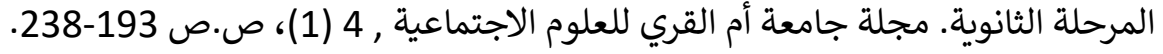
عبد الستار إبراهيم (2008). عين العقل؟ دليل المعالج المعرفي لتنمية التفكير العقلاني الإيجابي. القاهرة: دار الكاتب للطباعة والنشر. عبد الله علي الشهري (2007). فاعلية الارشاد الانتقائي في خفض مستوي سلوك العنف لدي المراهقين. رسالة

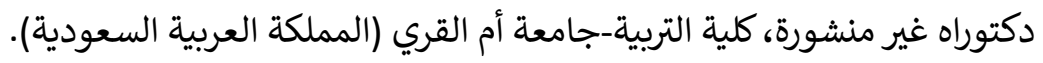
عبير محمد علي (2009). فاعلية برنامج ارشادي معرفي سلوكي لتنمية مهارات الحياة لدي عينة من الشباب

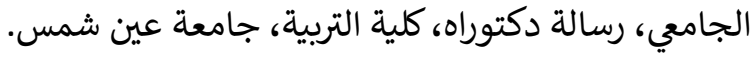
علاء الدين إبراهيم النجمة (2008). مدي فاعلية برنامج إرشادي نفسي التخفيف من أعراض الاكتئاب عند طلاب

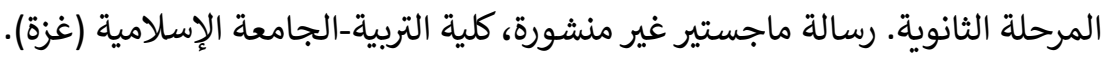


علاء الدين بدوي فرغلي (2008). مهارات العلاج المعرفي السلوكي. الطابعة الثانية، القاهرة: مكتبة النهضة المصرية.

على الصبحين (V) . . . إ). أثر برنامج إرشاد جمعي عقلاني انفعالي سلوكي في تخفيض سلوك الاستقواء لدى طلبة

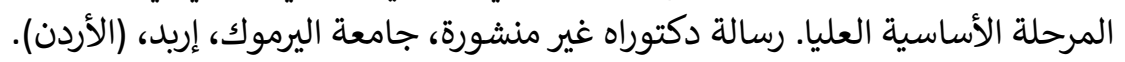

فردوس خضير عباس (2015). السلوك التوكيدي وعلاقته بالتكيف الاجتماعي المدروس لدي طالبات المرحلة

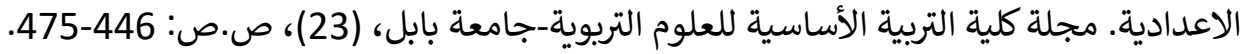

ماجدة محمد زقوت (2011). هوية الذات وعلاقتها بالتوكيدية والوحدة النفسية لدي مجهولي النسب. رسالة ماجستير غير منشورة، كلية التربية-الجامعة الإسلامية (غزة).

محمد نشأت أبو حسونة (2016). فاعلية برنامج إرشادي يستند إلى استراتيجية النمذجة المعرفية ولعب الدور في

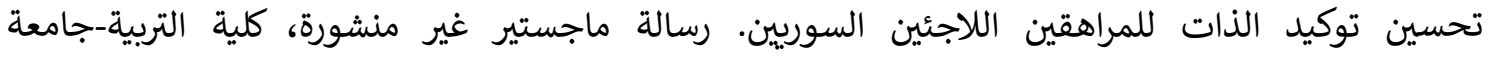
اليرموك(الأردن).

محمود صابر علي (2012). برنامج إرشادي معرفي سلوكي لتنمية توكيد الذات لدي عينة من الشباب الجامعي.

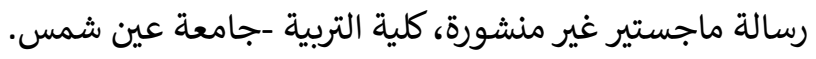

مصطفي رشاد الأسطل (2010). الذكاء العاطفي وعلاقته بمهارات مواجهة الضغوط لدي طلبة كلية التربية بجامعة

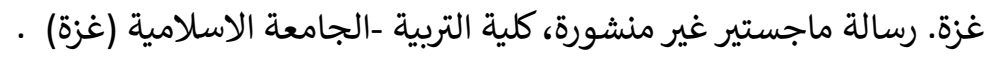
معتز محمد عبيد (2010). العلاقة بين التوكيدية والانتماء لعينة من الشباب الجامعي المؤتمر السنوي الخامس عامس الإس عشر. مركز الإرشاد النفسي-جامعة عين شمس، القاهرة. مني عبد الرازق ابو شنب (2017). فاعلية برنامج ارشادي معرفي سلوكي في خفض اليأس وأثره علي جودة الحياة

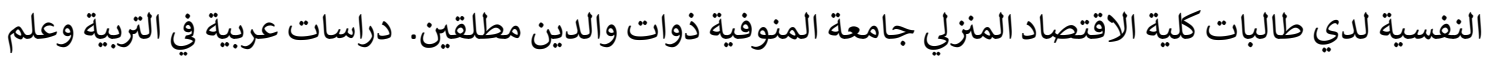

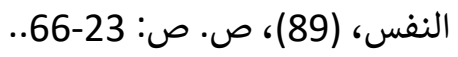

مني كامل شمس الدين، (2007). توكيد الذات الاجتماعية وعلاقتها بالسلوك الملبسي لدي طلاب كلية الاقتصاد

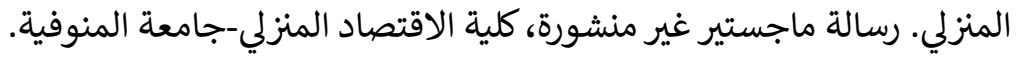

منار مصطفي نشأت (2018). فاعلية برنامج ارشادي يستند الي استراتيجيتي النمذجة المعرفية ولعب الدور في

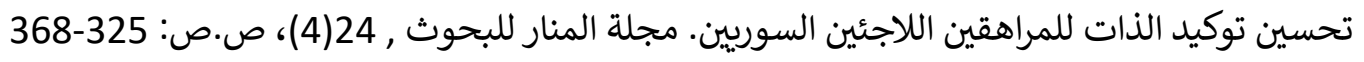
مهدي العوض (2017). توكيد الذات وعلاقته باتخاذ القرار لدي عينة من طلبه جامعة دمشق. مجلة جامعة

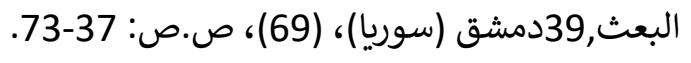


نادية بومجان (2016). برنامج إرشادي معرفي سلوكي لتخفيف الضغط النفسي لدي الأستاذة الجامعية المتزوجة.

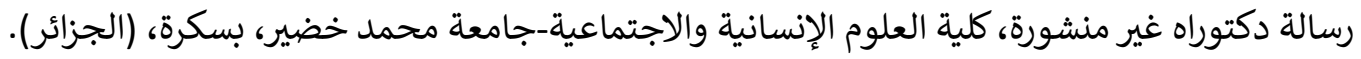
ناصر الدين ابراهيم أبو حماد (2014). فعالية برنامج ارشادي مستند الي النظرية المعرفية السلوكية في الارتقاء

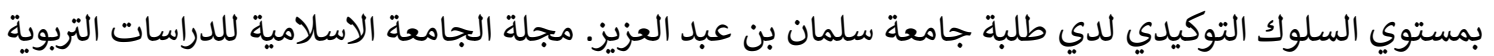
والنفسية,22(3)، ص.ص:129-129. نايف محمد الحربي (2013). قلق المستقبل وعلاقته بتوكيد الذات والتخصص والتحصيل الدراسي لدي طلاب

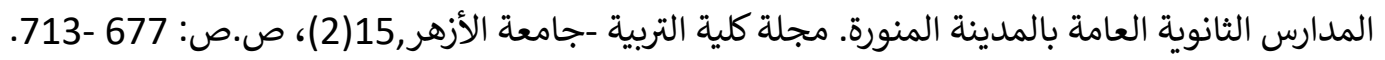
نبيله أحمد أبو حبيب (2010). الضغوط النفسية واستراتيجيات مواجهتها وعلاقتها بالتحصيل الدراسي لدي أبناء الشهداء في محافظات غزة. رسالة ماجستير غير منشورة، كلية التربية-جامعة الأزهر (غزة).

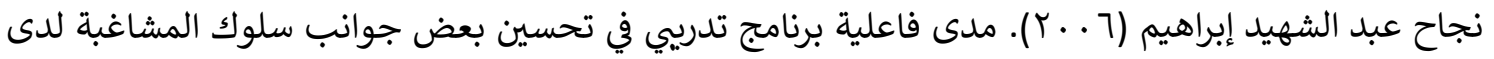

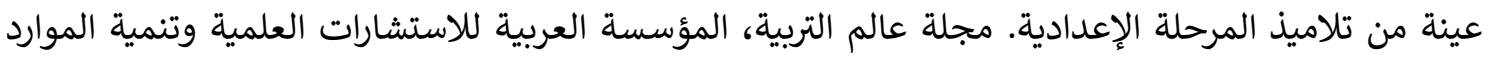

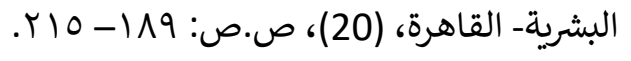

نجلاء بكري ياسين (2018). التوكيدية وعلاقتها بتقدير الذات لدي طالبات الجامعة. مجلة البحث العلمي في

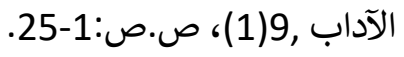

نشوة دردير (2010). الاحتراق النفسي للمعلمين ذوي النمط (أ، ب) وعلاقته بأساليب مواجهة المشكلات. رسالة ماجستير غير منشورة، كلية التربية-جامعة الفيوم (مصر). نعمة سيد خليل (2012). الضغوط النفسية وعلاقتها بالسلوك التوكيدي وجودة الحياة لدي الطلاب الوافدين في معاهد البعوث الإسلامية. رسالة ماجستير غير منشورة، كلية الدراسات الإنسانية -جامعة الأزهر. نور محمد عاقلة (2013). فاعلية برنامج إرشادي مستند إلى تفسير الأفكار اللاعقلانية في تحسين توكيد الذات لدي الطلبة. رسالة ماجستير غير منشورة، كلية الدراسات العليا-الجامعة الأردنية. نيلي حسين العروسي (2014). فعالية برنامج إرشادي نفسي (معرفي - سلوكي) لخفض الشعور بالخجل لدي عينة

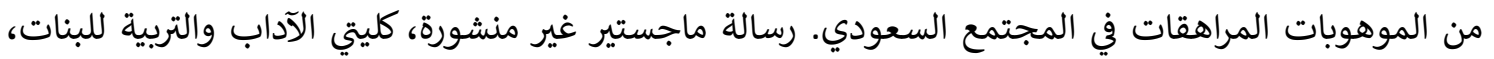
جامعة الملك خالد، أبها، (المملكة العربية السعودية) المجات المودي، هدي جمال محمد (2018). فاعلية برنامج إرشادي انتقائي تكاملي لتوكيد الذات لدي عينة من الأطفال ضحايا

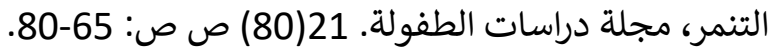
هدير عز الدين الاسي (2014). العلاج المعرفي السلوكي لاضطراب القلق العام، رسالة ماجستير غير منشورة. كلية التربية -الجامعة الاسلامية) غزة). 


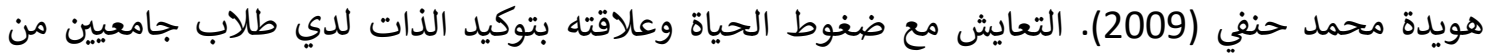

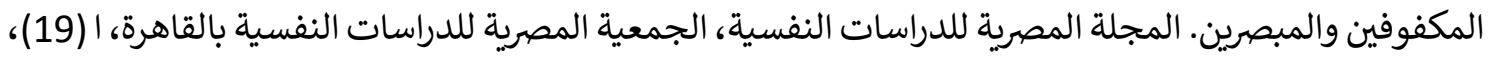
ص.ص: 410-488. ثانياً: المراجع الاجنبية Abed, G., El Amrosy, S. \& Atia, M. (2015). The effect of assertiveness training program on improving self-esteem of psychiatric nurses, Journal of Nursing Science, 1(1), 1-8, Published online (http//www.aascitorg/journal/jns)

Aspira Continuing Education (ACE) (2009) Cognitive behavioral therapy, available online (http//www.aspirace.com).

Corey, L. \& Gerald, J. (2010). Cognitive behavioral modification theory and practice of counseling and psychotherapy. Research and practice, clinical processes new practitioners, New York.

Esin, A. (2013). Levels of assertiveness and peer pressure of nursing students, International Journal of Caring Science, Bozok Health School University, Turkey, 6 (1), 78-86.

Erickson, A. G. \& Noonan, P. (2015). Assertiveness, College and Career Competency, online https://dese.mo.gov/sites/default/files/se-seap-teacher-guide.pdf).

Karagözoglu, S., Kahve, E., \& Adamisoglu, D. (2008). Self -esteem and assertiveness of final year Turkish University students, Nurse Education Today, 28(5), 641-649.

Kellecil, M. (2014). Effects of the anger management program based on cognitive behavioral techniques on high school students' anger and assertiveness levels, Anadolu Psikiyatri Dergisi,15, (4), 296-303.

Leichsenring, F., Weissber, M. \& Leibing, E. (2006). Cognitive behavior therapy and psychodynamic psychotherapy: techniques, efficacy and indications, American Journal of Psychotherapy, 60 (3), 233-259.

Liyaghat, R., Maddahi, M., Khalatbari, J. \& Samadzadeh, M. (2011). Effects of cognitive therapy and training program on self-assertiveness and parenting style, Journal of Basic and Applied, Islamic Azad University, Iran, 1(12), 3376-3382.

JHE, 2021, 31(2): pp 267-308 . يتم طباعتها في جامعة المنوفية، جميع حقوق الطبع محفوظة للمجلة. 
Rezayat, F. D. (2014). The level of depression and assertiveness among nursing students, Department of Psychiatric Nursing, University of Medical Sciences, Tehran, Iran, 2 (3), 177-84.

Secer, I. A. (2014). The effect of group counseling program on grade students assertiveness levels, Journal of Social Sciences, University of Gaziantep, (13), 245-257.

Stacie, A. and Collen, S.(2008). Bullying Prevention in the Elementary Classroom using Social Skills. Unpublished Master Thesis, Saint Xavier University, Chicago.

Solfa, H. Samia, A. \& Laila, H. (2011). The effect of assertiveness training program, Journal of American Science, 7(12), 1085-1096.

Votan-Acar, N. (2008). Assertiveness level of university students, University Journal of Education, 35(4), 342-350.

Warland, J. (2014). Assertiveness training for undergraduate midwifery students, Nurse Education in practice, University of South Australia, 14 (6), 6-52.

Wilson, D.J. (2011). Teacher perse ptives on positive behavior support used to manage challenging behavior in elementary school, PhD, Capella university.

Yektatalab, S. (2009). An assessment of the assertiveness among students of Jahrom University of Medical Sciences, European Psychiatry, 24, 738-738. 


\title{
The Effectiveness of a Behavioral Cognitive Conductive Program of Developing Self-assertiveness and Its Effectiveness on Coping Styles With Stresses among Faculty of Home Economics Students
}

\author{
Abd El A. Agwa1, Mona Abo Shanab² , Maha G. Shoaib², Amira I. Al-Kadeem ${ }^{2}$ \\ ${ }^{1}$ Department of Psychological Education, Faculty of Education, Menoufia University, Shibin El Kom, Egypt \\ 2 Department of Home Economics and Education, Faculty of Home Economics, Menoufia University, Shibin El Kom, \\ Egypt
}

\section{Abstract:}

The current research aimed at examining the effectiveness of cognitive conductive program in developing self-assertiveness and its effectiveness on coping styles with stresses among Faculty of Home Economics Students, Menoufia University. The current research was conducted on sample of (30) female student of third grade in Home Economics and Education at the Faculty of Home Economics, Menoufia University. The tools applied were Self- Assertiveness Scale and Coping Styles with Stresses Scale. The main results show there is a statistically significant difference at the level of (0.01) between the scores of the experimental group students in the pre- and postmeasurement for the Self- Assertiveness Scale as a whole and its sub-dimensions (Awareness of assertive rights, self-expression, expression of emotions, social boldness, affirmative communication with others, cognitive construction). also for The Coping Styles with Stresses Scale as a whole and its sub-dimensions. (Taking responsibility, logical analysis of the problem and focusing on it, searching for information to make the appropriate decision, facing the problem and addressing it, positive reinterpretation, surrendering to the problem and accepting the reality, behavioral withdrawal and the search for alternative evidence) in favor of the post application, and There is no a statistically significant difference between the scores of the experimental group students in the post and tracheal measurement for the self- assertiveness scale as a whole and its sub-dimensions and the coping styles with stresses scale as a whole and its sub-dimensions.

Keywords: Behavioral Cognitive Conductive- Self- assertiveness- Coping Styles with Stresses - 